\title{
The Role of NKT Cells in Tumor Immunity
}

\author{
Masaki Terabe and Jay A. Berzofsky \\ Vaccine Branch, Center for Cancer Research, National Cancer Institute, NIH
}

\begin{abstract}
NKT cells are a relatively newly recognized member of the immune community, with profound effects on the rest of the immune system despite their small numbers. They are true $\mathrm{T}$ cells with a $\mathrm{T}$ cell receptor (TCR), but unlike conventional $\mathrm{T}$ cells that detect peptide antigens presented by conventional major histocompatibility (MHC) molecules, NKT cells recognize lipid antigens presented by CD1d, a non-classical MHC molecule. As members of both the innate and adaptive immune systems, they bridge the gap between these, and respond rapidly to set the tone for subsequent immune responses. They fill a unique niche in providing the immune system a cellular arm to recognize lipid antigens. They play both effector and regulatory roles in infectious and autoimmune diseases. Furthermore, subsets of NKT cells can play distinct and sometimes opposing roles. In cancer, type I NKT cells, defined by their invariant TCR using V $\alpha 14 \mathrm{~J} \alpha 18$ in mice and V $\alpha 24 \mathrm{~J} \alpha 18$ in humans, are mostly protective, by producing interferon- $\gamma$ to activate $\mathrm{NK}$ and $\mathrm{CD} 8^{+} \mathrm{T}$ cells and by activating dendritic cells to make IL-12. In contrast, type II NKT cells, characterized by more diverse TCRs recognizing lipids presented by CD1d, primarily inhibit tumor immunity. Moreover, type I and type II NKT cells counter-regulate each other, forming a new immunoregulatory axis. Because NKT cells respond rapidly, the balance along this axis can greatly influence other immune responses that follow. Therefore, learning to manipulate the balance along the NKT regulatory axis may be critical to devising successful immunotherapies for cancer.
\end{abstract}

\section{INTRODUCTION/BACKGROUND}

\section{A. Overview}

NKT cells are a unique small subpopulation of true T cells, not NK cells, that nevertheless play a major role in regulating immune responses by bridging the innate and adaptive immune systems. Like cells of the innate immune system, NKT cells are among the first responders on the scene in a variety of infectious and inflammatory responses, and they set the stage and the tone for the subsequent adaptive immune response. They are pre-armed with cytokine mRNA, and can produce cytokines very quickly on activation. These cytokines can then determine the nature and quality of the antigen-specific $\mathrm{T}$ cell response that ensues. Like true $\mathrm{T}$ cells, they have an antigen-specific $\mathrm{T}$ cell receptor (TCR) that allows them to recognize both self antigens and foreign antigens, and they provide the immune system with a mechanism for detecting lipid antigens not detected by conventional T cells. Their name was based on the original observation of expression of NK cell markers not present on conventional T cells except when activated, but these NK markers are no longer a pre-requisite for defining NKT cells as we currently understand them. They have been found to play an important role in regulating transplantation tolerance, autoimmune disease, allergic disease and asthma, inflammatory responses, and infectious diseases ranging from bacteria and viruses to fungi and parasites.

Correspondence: Dr. Masaki Terabe, Vaccine Branch, CCR, NCI. Building 10-Room 6B-12, National Institutes of Health, Bethesda, MD 20892-1578. Tel: 301-435-8349; email: E-mail: terabe@ mail.nih.gov Or Dr. Jay A. Berzofsky, Vaccine Branch, CCR, NCI. Building 10—Room 6B-04, National Institutes of Health, Bethesda, MD 20892-1578. Tel: 301-496-6874; email: E-mail: berzofsk@ helix.nih.gov. 
In cancer, NKT cells were originally found in mostly a protective role, but more recently they have been found to also inhibit tumor immunosurveillance as well as cancer immunotherapy. This paradoxical behavior has now been found to be due to the presence of different subsets of NKT cells that mediate different functions. In one dichotomy between NKT cells with an invariant TCR (Type I) and those with more variable TCRs (Type II), these types have been found recently to cross-regulate each other and thus to form a new immunoregulatory axis that can modulate subsequent immune responses. NKT cells can also regulate other innate immune cells such as dendritic cells, myeloid-derived suppressor cells, and NK cells. In this review, we will focus on the role of different subsets of NKT cells in the immune response to cancer, both natural and induced, while also briefly reviewing their role in other disease processes to illustrate their potential activities where these have been better described in those diseases. We will first discuss each type of NKT cell and its function, and then discuss their interactions with each other and other cells and the potential translational/clinical applications of this knowledge. We conclude that learning to manipulate NKT cell function may lead to novel methods to treat or prevent cancer, or to synergize with other immunotherapies of cancer.

\section{B. Discovery of NKT cells}

The discovery of NKT cells was not a single "Eureka moment" that occurred a one point in time, but rather a gradual process in which at least three developing independent lines of evidence from different subfields of immunology converged to lead to the definition of the NKT cell and the subsequent evolution of that concept to the understanding that we have today (Bendelac et al., 1997; Bendelac et al., 2007; Godfrey et al., 2004; Macdonald, 2007; Taniguchi et al., 2003). It is of interest to note that one of the first lines of evidence was from an unexpected finding in examining the TCR repertoire of a series of suppressor T cell hybridomas, which were all found to use the same $\mathrm{V} \alpha$ chain $(\mathrm{V} \alpha 14)$, the same $\mathrm{J} \alpha$ segment $(\mathrm{J} \alpha 281$, now called Ja18), and the same single N-region glycine residue (Imai et al., 1986; Koseki et al., 1989). Thus, one of the earliest lines of evidence for the existence of NKT cells also indicated a potential regulatory role for these cells. Cells with this unique TCR were subsequently found at a surprisingly high frequency for a single TCR chain, at $1-2 \%$ of mouse spleen cells, 10 $20 \%$ of liver hematopoietic mononuclear cells, and $40 \%$ of $\mathrm{CD}^{+} \mathrm{T}$ cells in the bone marrow (Cui et al., 1997; Koseki, et al., 1989; Lantz and Bendelac, 1994; Makino et al., 1995). The fact that these cells used the same TCR $\alpha$ chain in mice of multiple MHC types suggested that they may be recognizing a monomorphic MHC molecule rather than the conventional polymorphic ones that differed among mouse strains.

Another line of evidence also related to TCR repertoire. Two groups reported the presence of a small number $(0.4 \%)$ of mouse thymocytes that expressed V $\beta 8$ despite being $\mathrm{CD} 4^{-} \mathrm{CD} 8^{-}$ double negative, a population that had been thought to be too immature to express a TCR, and these were found to be $\mathrm{CD}_{4} 4^{+}, \mathrm{CD}^{+}$and NK1.1 ${ }^{+}$(Ballas and Rasmussen, 1990; Budd et al., 1987; Fowlkes et al., 1987; Sykes, 1990). These cells were also characterized in almost every case as producing copious amounts of cytokines. A similar population was identified among mature CD4 ${ }^{+}$T cells (Arase et al., 1992; Bendelac et al., 1994a; Hayakawa et al., 1992; Takahama et al., 1991; Takahama and Singer, 1992). These cells were also found to express lower levels of CD3 (Arase et al., 1993; Arase, et al., 1992; Bendelac, et al., 1994a; Levitsky et al., 1991).

The third line of evidence helped to tie these two lines together and explain the invariant TCR. Lantz and Bendelac were able to produce thymocyte hybridomas that were $\mathrm{V} \beta 8^{+}$, CD5 high and CD $44^{+}$, and these were found to have mRNA for the V $\alpha 14$ TCR chain (Lantz and Bendelac, 1994). Similarly, the V $\alpha 14^{+}$cells in peripheral tissues were found to also express predominantly V $\beta 8$ and NK1.1 (Makino, et al., 1995; Taniguchi et al., 1996). Thus, the unusual $\mathrm{V} \beta 8^{+}$cells in the thymus turned out to be the same cells (or precursors) as the invariant TCR 
$\mathrm{V} \alpha 14^{+}$cells originally detected as suppressor $\mathrm{T}$ cell hybridomas. Further, these V $\alpha 14 / \mathrm{V} \beta 8$ thymocyte hybridomas were found to recognize a relatively monomorphic non-classical class I-like MHC molecule, CD1d, explaining their ability to use a nearly identical TCR in mice of different MHC types (Bendelac, 1995; Bendelac et al., 1995). This explained the finding that NK1. $1^{+}$TCR $\alpha \beta$ T cells in liver, whether $\mathrm{CD}^{+}{ }^{+}$or $\mathrm{CD}^{-} \mathrm{CD}^{-}$double negative, required $\beta 2-$ microglobulin and thus a molecule in the class I MHC family (Ohteki and MacDonald, 1994). Thus, the concept gradually emerged of a specialized subset of TCR $\alpha \beta^{+} \mathrm{T}$ cells that recognized antigens presented by the class I-like MHC molecule CD1d, expressed NK1.1, high levels of CD5 and CD44, and usually expressed a particular semi-invariant TCR using the V $\alpha 14 \mathrm{~J} \alpha 18$ TCR $\alpha$ chain and most often a V $\beta 8$ (and more recently also V $\beta 2$ or V $\beta 7$ ) TCR $\beta$ chains. The concept was further solidified when it was discovered that these cells responded to a glycolipid antigen, $\alpha$-Galactosylceramide ( $\alpha$-GalCer), derived from a marine sponge or microorganisms symbiotic with the sponge (Kawano et al., 1997). These cells were termed NKT cells (Godfrey, et al., 2004; Makino, et al., 1995) because of their NK cell-like expression of NK1.1 despite being true $\mathrm{CD}^{+} \mathrm{T}$ cells. Similar $\mathrm{V} \alpha 24 \mathrm{~J} \alpha 18^{+} \mathrm{V} \beta 11^{+} \mathrm{NKT}$ cells were found in humans, in which $\mathrm{V} \alpha 24$ and $\mathrm{V} \beta 11$ are the human homologs of $\mathrm{V} \alpha 14$ and V $\beta 8$ (Dellabona et al., 1994; Porcelli et al., 1993).

\section{Evolution of the definition and classification of NKT cells}

As noted above, NKT cells were originally defined based on their expression of NK-like markers such as NK1.1 (CD161) even though they were true CD3 ${ }^{+}$T cells. However, confusion arose early on about what cells really constituted the NKT population (Godfrey, et al., 2004). NKT was interpreted to mean natural killer T cells even though these cells were not particularly characterized by NK-like functions, although they were part of the innate immune system. Also, NK1.1 was not expressed in many mouse strains, and T cells that otherwise fit the definition of NKT cells, including expression of the invariant $\mathrm{V} \alpha 14 \mathrm{~J} \alpha 18^{+} \mathrm{V} \beta 8^{+} \mathrm{TCR}$ and recognition of CD1d, were sometimes found to be NK1.1 negative. Also, conventional T cells, when activated, express NK1.1 as an activation marker, so this was not a reliable marker to distinguish NKT cells from conventional class I or class II MHC-restricted T cells (Assarsson et al., 2000; Slifka et al., 2000; Terabe et al., 2008). For all these reasons, the definition of NKT cells was modified to encompass all true TCR $\alpha \beta \mathrm{T}$ cells that were restricted by the nonclassical class I MHC molecule CD1d (Godfrey, et al., 2004).

Even within this CD1d-restricted population now defined as NKT cells, different subsets could be defined. The major distinction was between the classical NKT cells expressing the invariant V $\alpha 14 \mathrm{~J} \alpha 18$ TCR in the mouse or V $\alpha 24 \mathrm{~J} \alpha 18$ in the human, called type I NKT cells (also known as invariant NKT cells or iNKT cells), and another subset of cells that were also CD1drestricted but expressed more diverse TCRs, not employing the canonical V $\alpha 14 \mathrm{~J} \alpha 18$ or V $\alpha 24 \mathrm{~J} \alpha 18$, which were dubbed type II NKT cells (Godfrey, et al., 2004) (Table I). The discovery and characterization of the latter subset will be discussed in Section III.A later. However, it was clear that the only common characteristic was the CD1d restriction, and therefore the absence of all NKT cells (both type I and type II) in CD1d deficient mice. Therefore, also, the development of CD1d- $\alpha-$ GalCer tetramers made it possible to uniquely and unambiguously identify type I NKT cells by flow cytometry (Benlagha et al., 2000; Karadimitris et al., 2001; Matsuda et al., 2000), but unfortunately, CD1d tetramers that identify all type II NKT cells are not available (although a subset may be identifiable by CD1d-sulfatide tetramers (Jahng et al., 2004) as discussed in Section III.A). A consequence of this definition is that because CD1d was found to present lipids or glycolipids rather than peptides (Bendelac, et al., 2007; Brutkiewicz, 2006; Tupin et al., 2007), NKT cells are the primary class of T cells that can provide the immune system with a mechanism of specific recognition of lipid antigens, whether from self or from microbial invaders. These are reviewed under the individual subsets. Other independent characteristics used to define subsets of NKT cells include $\mathrm{CD}^{+}{ }^{+}$vs 
$\mathrm{CD} 4^{-} \mathrm{CD} 8^{-}$double negative populations, and NK1.1 ${ }^{+}$and $\mathrm{NK} 1.1^{-}$populations, as well as tissue origin (Ambrosino et al., 2008; Berzofsky and Terabe, 2008; Terabe and Berzofsky, 2007). These will be discussed below in the context of functional activities of type I or type II NKT cells.

\section{The place of NKT cells in the overall immune system}

NKT cells are positioned to play a pivotal role in the immune system, as they form a bridge between the innate and adaptive immune systems, having a foot in both camps. They have true TCRs and antigen specificity like conventional T cells, albeit for lipids rather than peptides, but they also have a more limited repertoire and rapid response characteristic of the innate immune system. Other true T cells that have such specialized function exist, such as $\gamma \delta$-T cells and MAIT (mucosal associated invariant T) cells. Like NKT cells, MAIT cells express a canonical TCR, in this case using the V $\alpha 19 \mathrm{~J} \alpha 33$ chain in mice and V $\alpha 7.2 \mathrm{~J} \alpha 33$ in humans, and they also appear to play a regulatory role (Shimamura and Huang, 2002; Treiner et al., 2003). Unlike NKT cells, they depend on the gut flora and are absent in germ-free mice. Some $\gamma \delta$-T cells also express NK-like markers and fill unique niches (Arase et al., 1995; Carding and Egan, 2002; Lees et al., 2001; Vicari et al., 1996). At various times, some of these have been included in the category of NKT cells but are now recognized to be distinct T cell subsets.

Like innate immune cells, NKT cells are rapid responders on the scene when the immune system is activated, and help to call into play other members, ranging from NK cells of the innate immune system to conventional $\mathrm{CD}^{+}{ }^{+}$or $\mathrm{CD}^{+} \mathrm{T}$ cells of the adaptive immune system. Thus, their regulatory role can be pivotal in orchestrating other responses that come later. From the earliest studies on NKT cells as described above, even before the term NKT cells was applied, they were found to be copious producers of cytokines, both Th1 cytokines like interferon- $\gamma$ and Th2 cytokines like IL-4 or IL-13 (Table I). Two recent studies have found that an NK1.1-negative subset of type I NKT cells can rapidly produce IL-17, contributing to neutrophil recruitment (Michel et al., 2007; Rachitskaya et al., 2008). NKT cells can also make IL-21, which can act back on NKT cells in an autocrine fashion (Coquet et al., 2007). It is now understood that the rapid cytokine response relates in part to the presence of preformed mRNA for cytokines such as interferon- $\gamma$ and IL-4, allowing the cell to respond more quickly without the need for gene transcription (Matsuda et al., 2003; Stetson et al., 2003). The presence of the preformed mRNA in turn may relate to the recognition of self antigens that keep the NKT cells primed to respond, as suggested by their ability to respond to IL-12 produced by macrophages or dendritic cells (DCs) stimulated by bacterial LPS, even in the absence of an exogenous CD1d-presented specific antigen (Brigl et al., 2003). This very early production of cytokines by NKT cells was proposed as a potential solution to the dilemma that it takes IL-4 to induce a Th2 cell to make IL-4, so where does the initial IL-4 come from to initiate the process? It was found that IL-4 from NKT cells could promote Th2 responses and IgE production, and that defective IgE production in SJL mice was related to the absence of CD4 ${ }^{+} \mathrm{NKT}$ cells that made IL-4 (Yoshimoto et al., 1995a; Yoshimoto et al., 1995b). Although NKT cells may not be the only such source of early IL-4, their ability to respond first and steer subsequent adaptive responses makes their regulatory functions all the more influential throughout the immune system.

NKT cells also function as part of the adaptive immune system, in filling a void in the antigen repertoire of conventional T cells, which generally recognized only peptide fragments of proteins, not lipids. The ability of NKT cells to recognize self lipids, discussed below under the individual subsets, may be one reason they can have profound impact on autoimmune disease. On the other hand, their ability to recognize bacterial lipids, also outlined below, gives the adaptive T-cell immune system another handle on invading microbes, by detecting their lipid content as well as their proteins (Bendelac, et al., 2007; Brutkiewicz, 2006; Kinjo et al., 
2005; Tupin, et al., 2007). Thus, NKT cells serve as regulatory cells and potentially effector cells in responses ranging from autoimmune disease and allergy to infectious diseases and cancer.

\section{TYPE I NKT CELLS}

\section{A. Characterization and Development of Type I NKT cells}

As noted above, type I NKT cells (also known as invariant NKT cells or iNKT cells) are defined by their expression of the canonical invariant $\mathrm{V} \alpha 14 \mathrm{~J} \alpha 18 \mathrm{TCR} \alpha$ chain in the mouse (V $\alpha 24 \mathrm{~J} \alpha 18$ in the human) and a limited number of TCR $\beta$ chains, $V \beta 8, V \beta 7$, and $V \beta 2$ in the mouse and $\mathrm{V} \beta 11$ in the human, and their recognition of lipids presented by CD1d. Their recognition of a particularly strong agonist prototype lipid, $\alpha-$ GalCer, although it is neither a natural mammalian product nor a product of a known mammalian pathogen, has helped to define them functionally (Kawano, et al., 1997; Taniguchi, et al., 2003). The combination of these three properties makes possible their operational definition by their unique and specific binding of tetramers (or dimers or pentamers) of CD1d loaded with $\alpha$-GalCer or its analogs (Benlagha, et al., 2000; Karadimitris, et al., 2001; Matsuda, et al., 2000). The advent of these multimers of CD1d has greatly facilitated characterization of these cells in both mice and humans, especially in the absence of a practical antibody for $\mathrm{V} \alpha 14$, although anti-V $\alpha 24$ is available for human NKT cell staining. (However, $\alpha$-GalCer recognition alone is not diagnostic of type I NKT cells, because at least in humans, some type II NKT cells lacking the invariant TCR can nevertheless respond to $\alpha$-GalCer (Gadola et al., 2002), so in humans the presence of V 224 combined with CD1d tetramer binding may be more definitive.) Other markers are often present, such as NK1.1 and Ly49 NK receptors, CD69 and CD44, but none of these other molecules is definitive. As noted earlier, NK1.1 is absent from several mouse strains such as $\mathrm{BALB} / \mathrm{c}$ and NOD, and type I NKT cells have been found to come in both NK1.1 $1^{+}$and NK1.1 ${ }^{-}$subsets with potentially different functional activity (Kronenberg, 2005) (Chiu et al., 1999; McNab et al., 2007). Likewise, they can be divided into $\mathrm{CD} 4^{+}$and $\mathrm{CD} 4^{-} \mathrm{CD} 8^{-}$double negative (DN) subsets in the mouse, and may even express CD8 $\alpha \alpha$ in the human as well (Bendelac et al., 1994b). In the case of this latter categorization, a functional difference has been defined at least in the human, albeit less clearly in the mouse. In two independent studies, human DN type I NKT cells were found to express mostly Th1 cytokines like interferon- $\gamma$, whereas $\mathrm{CD} 4^{+}$type I NKT cells expressed both Th1 cytokines and Th 2 cytokines like IL-4 and IL-13 (Gumperz et al., 2002; Lee et al., 2002a).

Type I NKT cells have also been distinguished by their tissue localization. NKT cells have their highest prevalence in the liver, where they may represent up to $30 \%$ of $\mathrm{CD}^{+} \mathrm{T}$ cells in the mouse (Bendelac, et al., 2007). The liver-resident type I NKT cells are not only more prevalent, but also show different functional characteristics, in that they have been shown to be more protective against tumors than NKT cells from the spleen or thymus (Crowe et al., 2005). The protective subset was also found to be primarily $\mathrm{DN}$, rather than $\mathrm{CD}^{+}$, consistent with the role of interferon- $\gamma$ in tumor protection. These studies will be discussed further in the context of tumor immunity.

Type I NKT cell development has been studied and reviewed extensively (Bendelac, et al., 2007; Godfrey and Berzins, 2007; Kronenberg, 2005; Macdonald, 2007; MacDonald and Mycko, 2007) and will be summarized only briefly here. Although initially controversial, it is now agreed that type I NKT cells develop in the thymus, starting from double positive thymocyte precursors, when the rearranged TCRs are first expressed. The rearrangement and/ or selection of the $\mathrm{V} \alpha 14 \mathrm{~J} \alpha 18-\mathrm{V} \beta 8 / 7 / 2$ receptors depends on a number of factors, including the retinoic acid-related orphan receptor ROR $\gamma t$ (Bezbradica et al., 2005; Egawa et al., 2005), the src-fmaily kinase fyn (Eberl et al., 1999; Gadue et al., 1999), and the upstream signaling molecule SLAM-associated protein (SAP) in both mice and humans (Chung et al., 2005; 
Nichols et al., 2005; Pasquier et al., 2005), so that a knock-out of any one of these leads to the absence of type I NKT cells. Restoration of NKT cells in $\mathrm{fyn}^{-1-}$ mice with a V $\alpha 14 \mathrm{~J} \alpha 18$ transgene suggested that these molecules operated upstream of the TCR rearrangement (Gadue et al., 2004), but this interpretation has recently been questioned because the $\mathrm{SAP}^{-/-}$was not reconstituted (Bendelac, et al., 2007), suggesting that they may really play more of a role in V $14 \mathrm{~J} \alpha 18 \mathrm{TCR}$ signaling and positive selection. These NKT cell precursors appear to arise stochastically, but when an appropriate combination of $\mathrm{V} \alpha 14 \mathrm{~J} \alpha 18$ and $\mathrm{V} \beta 8,7$, or 2 occurs randomly, those cells are positively selected and expanded. Another striking difference between type I NKT cells and conventional class I and II MHC-restricted CD4 ${ }^{+}$and CD8 ${ }^{+} \mathrm{T}$ cells is that the positive selection of type I NKT cells is mediated by CD1d expressing endogenous ligands on double positive thymocytes (of hematopoietic cell lineage), whereas that of conventional $\mathrm{T}$ cells is mediated by thymic epithelial cells (not hematopoietic in origin) (Wei et al., 2005; Zimmer et al., 2006).

The NKT precursors go through a series of stages after the double positive stage in which they are $\mathrm{CD}^{+}$, regardless of their eventual $\mathrm{CD}^{+}$or DN phenotype (Bendelac, et al., 2007; Godfrey and Berzins, 2007; Kronenberg, 2005; Macdonald, 2007; MacDonald and Mycko, 2007). These include a $\mathrm{CD} 4{ }^{+} \mathrm{CD} 24^{\text {high }} \mathrm{CD} 44^{\text {low }} \mathrm{NK} 1.1^{\text {neg }}$ non-cycling stage followed by a $\mathrm{CD} 4{ }^{+} \mathrm{CD} 24^{\text {low }} \mathrm{CD} 44^{\text {low }} \mathrm{NK} 1.1^{\text {neg }}$ cycling stage and then a CD4 $4^{+} \mathrm{CD} 24^{\text {low }} \mathrm{CD} 44^{\text {high }} \mathrm{NK} 1.1^{\text {neg }}$ cycling stage, finally leading to a mature $\mathrm{CD} 4{ }^{+/-} \mathrm{CD} 24^{\text {low }} \mathrm{CD} 44^{\text {high }} \mathrm{NK} 1.1^{+}$noncycling stage. It appears that molecules such as ROR $\gamma \mathrm{t}$, fyn and SAP are important at the earliest stage, whereas NF- $\kappa \mathrm{B}$ and PKCtheta, downstream of these, are important when the cells start cycling in the second stage (Elewaut et al., 2003; Schmidt-Supprian et al., 2004; Sivakumar et al., 2003; Stanic et al., 2004), and then other molecules become critical at later stages, such as Tbet and IL-15. Indeed, the T-bet transcription factor, that was originally defined as required for interferon- $\gamma$ production (Szabo et al., 2000) was found critical for NKT cell development in that in T-bet ${ }^{-/-}$mice, type I NKT cell development was blocked at the third $\left(\mathrm{CD} 44^{\text {high }} \mathrm{NK} 1.1^{\text {neg }}\right.$ ) stage (Townsend et al., 2004). Likewise, IL-15 ${ }^{-/-}$mice (Kennedy et al., 2000) or IL-15R $\alpha^{-1-}$ or IL-15R $\beta^{-/-}$mice (Lodolce et al., 1998; Ohteki et al., 1997), which lack IL-15 or cannot respond to it, were found to be completely or markedly deficient in type I NKT cells. However, the requirement for IL-15 appears to be only at the last stage of development $\left(\mathrm{CD} 44^{\text {high }} \mathrm{NK} 1.1^{+}\right.$) when the CD122 receptor (IL-2/15R $\beta$ chain) is upregulated. It is of interest that despite the dependence of type I NKT cell development on IL-15 as shown from KO mice, these cells (defined by $\alpha$-GalCer-loaded CD1d-tetramer binding) are not increased at all in absolute numbers in the spleens of IL-15 transgenic mice that overexpress IL-15 (Terabe, et al., 2008). These mice have increased numbers of $\mathrm{CD}^{+} \mathrm{NK} 1.1^{+}$cells, many of which are $\mathrm{CD} 8^{+}$, but when further analyzed, these turned out to be a roughly equal mixture of conventional TCR $\alpha \beta C D 8 \alpha \beta$ T cells that had upregulated NK1.1 probably due to activation, and a normally much rarer TCR $\alpha \beta C D 8 \alpha \alpha$ T cell that is expanded in the presence of high levels of IL-15 from CD8 $\alpha^{+}$but CD8 $\beta$ negative precursors and that is distinct from those found in the intraepithelial lymphocyte population of the gastrointestinal mucosa (Terabe, et al., 2008).

\section{B. Type I NKT cell antigen recognition}

1. FOREIGN/MICROBIAL ANTIGENS-With only a single invariant TCR V $\alpha$ chain and only a few possible $\mathrm{V} \beta$ chains, the type I NKT cells might be expected to have a very limited repertoire of antigens. Surprisingly, although they are restricted to a single essentially invariant MHC-like molecule CD1d, they recognize a range of lipid antigens from bacterial lipids to mammalian self lipids (Behar and Porcelli, 2007; Bendelac, et al., 2007; Brutkiewicz, 2006; Tupin, et al., 2007). As noted, the first agonist discovered for type I NKT cells was $\alpha$-GalCer, recovered from a marine sponge (Kawano, et al., 1997). Because mammalian cells do not syntheize glycolipids with such an alpha linkage, it was thought that this was not a natural 
ligand for mammalian CD1d, although it had very potent activity. However, in 2005, three groups independently discovered that type I NKT cells recognized lipids found in the cell wall of certain Gram-negative, LPS negative bacteria, Sphingomonas species and Ehrlichia species, such as $\alpha$-glucuronosylceramide, related to $\alpha$-GalCer (Kinjo, et al., 2005; Mattner et al., 2005; Sriram et al., 2005; Wu et al., 2005). In view of the fact that the marine sponge from which $\alpha$-GalCer was originally isolated is frequently symbiotically colonized by Sphingomonas $\alpha$-proteobacteria (Dieckmann et al., 2005), it is likely that the original $\alpha$-GalCer was derived from such a Sphingomonas symbiont rather than synthesized by the sponge itself. Importantly, this recognition of Sphingomonas lipids related to $\alpha$-GalCer was shown to be relevant to host defense, as the ability to clear such organisms was impaired by NKT cell deficiency (Kinjo, et al., 2005; Mattner, et al., 2005). Moreover, the ability to recognize bacterial lipids is not limited to non-pathogenic Sphinomonas species, as diacylglycerol antigens from the pathogenic Borrelia burgdorferi that causes Lyme disease were recently found to be presented by CD1d to type I NKT cells (Kinjo et al., 2006; Mattner, et al., 2005). In addition, phosphoinositol mannoside (PIM) from mycobacteria was found to stimulate type I NKT cells (Fischer et al., 2004), but the significance for clearance of $M$. tuberculosis from mice is unclear as $\mathrm{J} \alpha 18^{-/-}$mice were more susceptible (Sugawara et al., 2002) whereas

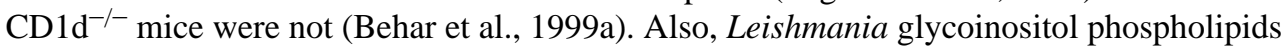
were presented by CD1d to stimulate type I NKT cells and were relevant to host defense as

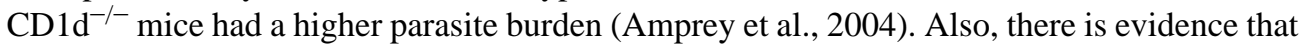
the Th2-skewed cytokine response in schistosomiasis is dependent on NKT cells and CD1d, and that this appears to be mediated early in infection by CD1d presentation of a schistosomederived glycoconjugate, although the specific antigen was not characterized (Faveeuw et al., 2002). Thus, there is now ample evidence that type I NKT cells recognize lipids from microorganisms, some of which are pathogenic, and thus presumably evolved for host defense. In this regard, they have aspects of both innate and adaptive immunity, in that they are antigenspecific, and provide the host with a cellular immune mechanism to detect lipid antigens from pathogens, broadening the immune repertoire from peptides recognized by conventional $\mathrm{T}$ cells, and yet also can respond rapidly like mediators of innate immunity. Moreover, in this role, they can recognize a surprisingly broad repertoire of microbial antigens with such a limited TCR diversity, indicating the plasticity of TCR recognition.

2. SELF-ANTIGENS-However, as noted earlier, NKT cells also seem to be pre-armed to respond to microbial antigens as if primed by self antigens (Brigl, et al., 2003). In that case, it was shown that these pre-armed cells responded to IL-12 induced by the bacterial infection (through Toll-like receptor (TLR) ligand (probably LPS) stimulation of dendritic cells and macrophages). However, because of this pre-arming and ability to regulate immune responses, a search has been long ongoing to find endogenous self antigens recognized by type I NKT cells. Among the first such self lipids to be extracted from CD1d of mammalian cells were glycosylphosphatidyl inositols (Joyce et al., 1998), and a related compound, phosphatidyl choline, was found in the CD1d groove after crystallization of recombinant CD1d prepared from insect cells (Giabbai et al., 2005). Some functional activity of phosphatidyl inositol from soybeans was found in screening activities on NKT hybridomas that also recognized murine tumors transfected with CD1d (Gumperz et al., 2000), and which express these phospholipids. The natural role for these molecules is unknown. However, there is also evidence for CD1d presentation of phospholipids from tree pollen to NKT cells from allergic subjects, so they may play a role in allergy (Agea et al., 2005). Alternatively, it has been suggested that the phospholipids may play a place-holder role like the CLIP peptide in class II MHC molecules, and then be exchanged for other lipids (Brutkiewicz, 2006). Indeed, loading of CD1d with exogenous ligands, at least for recognition by type I NKT cells, is dependent on lipid exchange molecules, saposins, present in endosomes (Kang and Cresswell, 2004; Zhou et al., 2004a), and the microsomal triglyceride transfer protein (MTP) present in the endoplasmic reticulum 
but also apparently functioning during CD1d recycling from lysosome to plasma membrane and thus possibly lipid loading in the lysosome (Brozovic et al., 2004; Dougan et al., 2005; Sagiv et al., 2007).

More recently, a candidate for a major self-antigen recognized by type I NKT cells, independent of $\mathrm{V} \beta$ usage, was identified by defective stimulation of type I NKT cells by cells deficient in beta hexosaminidase B, required for the synthesis of the glycosphingolipid isoglobotrihexosylceramide (iGb3) (Zhou et al., 2004b). The defect was specific, as these cells could still present exogenous lipids to NKT cells. Moreover, synthetic iGb3 could activate the majority of type I NKT cells, confirming this mammalian lipid as an antigen for NKT cells. It has been suggested that iGb3 is the main endogenous ligand, as beta-hexosaminidase Bdeficient mice had a 95\% reduction in NKT cell production in the thymus (Zhou, et al., 2004b). However, the presence of type I NKT cells in mice with iGb3 deficiency has recently suggested that other self lipids besides iGb3 must also exist (Porubsky et al., 2007; Speak et al., 2007).

3. STRUCTURE-FUNCTION STUDIES-Much chemistry has been done to examine the structure-function relationships among analogs of the original NKT cell antigen, $\alpha-\mathrm{GalCer}$ (Forestier et al., 2007; Miyamoto et al., 2001; Rauch et al., 2003; Schmieg et al., 2003; Spada et al., 1998). Some lipids, such as $\mathrm{OCH}$, have been weaker agonists than $\alpha$-GalCer, but have induced a cytokine profile skewed more toward that of a Th2 cell, with more IL-4 and less interferon- $\gamma$ (Miyamoto, et al., 2001), and this has been found protective in some autoimmune diseases, as discussed below. A recent study reported a more potent Th2-skewing analog, C20:2 (Forestier, et al., 2007). On the other hand, a C-glycoside analog of $\alpha$-GalCer was found to induce a response skewed more toward a Th1 cytokine profile, with more interferon- $\gamma$, and was more protective against malaria and melanoma (Schmieg, et al., 2003). Also, $\beta$-GalCer has been found to deplete NKT cells without activation of NK cells or cytokine production, indicating recognition without activation and providing a potential way to distinguish effects of NK and NKT activation (Ortaldo et al., 2004). Recently, even nonglycosidic antigens like threitolceramide were found to stimulate type I NKT cells (with lower affinity of the invariant TCR for the threitolceramide-CD1d complex than for the $\alpha$-GalCer complex) and had the advantage over $\alpha$-GalCer that the NKT cells recovered more quickly from activation-induced anergy and also were less likely to lyse the presenting DCs (Silk et al., 2008). Thus, the activity of NKT cells can be manipulated by selective utilization of ligands with different stimulatory properties.

\section{Type I NKT cells in infectious disease}

1. BACTERIAL INFECTIONS-As noted above, the specificity of NKT cells for certain bacterial and parasitic lipids suggests that they may have evolved for host defense, to provide a way to recognize certain pathogens. Sphingomonas species, which are Gram negative and LPS-negative, nevertheless can cause infection in immunocompromised hosts, and in high doses can cause lethal toxic shock, similar to that produced by LPS (Bendelac, et al., 2007). NKT cells seem to be a double-edged sword in this infection, because on the one hand they contribute to clearance of infection and clearance is enhanced substantially by NKT cell activation (Kinjo, et al., 2005; Mattner, et al., 2005), but on the other hand, they may be responsible for the immunopathology of toxic shock through production of cytokines or induction of other cells to make cytokines. Other alpha-proteobacteria that are Gram negative and LPS negative, such as the tick-borne rickettsial pathogen Erlichia, may be more important pathogens in immunocompetent humans and domesticated animals. NKT cells recognizing Erlichia lipids can contribute to protection against these organisms (Mattner, et al., 2005). Other pathogenic bacteria with lipids presented by CD1d were recently found to include Borrelia burgdorferi, the agent of Lyme disease, that can directly stimulate NKT cells (Kinjo, 
et al., 2006), and in at least one case, NKT cell deficiency was found to impair the defense against this spirochete (Kumar et al., 2000).

In contrast, LPS-expressing Gram negative bacteria, like Salmonella, activate NKT cells without direct recognition of any known bacterial lipid (Brigl, et al., 2003; Mattner, et al., 2005). It appears that these responses are dependent on self antigens, as they are absent when the dendritic cells presenting antigen lack beta-hexosaminidase B, required for generation of iGb3 (Mattner, et al., 2005), and they rather are dependent on IL-12 release by the dendritic cells in response to the LPS as a TLR ligand, since the response is dependent on the TLR adaptor protein MyD88 as well as on IL-12 (Brigl, et al., 2003; Mattner, et al., 2005). Another Gram-negative LPS-positive bacteria for which a protective role of NKT cells has been found is Pseudomonas aeruginosa infection of the lung, in which CD1d ${ }^{-1-}$ mice had a roughly 20fold higher bacterial count than their wild-type counterparts (Nieuwenhuis et al., 2002). However, surprisingly, NKT cells did not seem to play a role in liver infection with Pseudomonas, despite the greater prevalence of NKT cells in that organ (Muhlen et al., 2004). Yet a third mechanism may be at play in Chlamydia trachomatis infection, in which type I NKT cells appear to promote infection by promoting Th2 cytokine production (Bilenki et al., 2005). Thus, NKT cells can contribute to bacterial clearance through two distinct mechanisms, directly through recognition of bacterial lipids or indirect activation through LPSinduced IL-12-mediated stimulation of NKT cells already activated by self antigens, or may interfere with bacterial control through cytokine skewing.

2. PARASITIC INFECTIONS-NKT cells have also been found to play a role in parasitic diseases, although in only one case, that of Leishmania, has a parasitic lipid presented by CD1d been implicated in NKT cell activation and control of the parasite (Amprey, et al., 2004). However, Schistosoma mansoni infected mice had a weaker interferon- $\gamma$ response to the parasite if they lacked type I NKT cells, as in J $118^{-/-}$mice (Mallevaey et al., 2007). Further, the skewing of cytokines toward a Th2 profile in schistosomiasis appears to be dependent on an NKT cell response to parasite antigens making Th2 cytokines early in the infection (Faveeuw, et al., 2002). Also, in Trypanosoma cruzi infections, J $\alpha 18^{-/-}$mice lacking type I NKT cells had more severe disease (Duthie et al., 2005). However, in both of the latter diseases, $\mathrm{CD}_{1} \mathrm{~d}^{-/-}$mice behaved differently from $\mathrm{J} \alpha 18^{-/-}$mice, suggesting a different role for type II NKT cells, as discussed in Section III.B.7 below. Finally, in mouse malaria, $\alpha$-GalCer analogs that activate NKT cells to make interferon- $\gamma$ have been found to be protective (Schmieg, et al., 2003).

3. VIRAL INFECTIONS-NKT cells may also play a role in viral immunity. Clearance of at least one strain of herpes simplex virus type 1 (HSV-1) was impaired in CD1d ${ }^{-/-}$mice or $\mathrm{J} \alpha 18^{-/-}$mice that lack type I NKT cells (Grubor-Bauk et al., 2003), whereas clearance of another strain of HSV-1 appeared to be independent of NKT cells (Cornish et al., 2006). Similarly, CD1 $\mathrm{d}^{-1-}$ mice lacking NKT cells were about 10 -fold more sensitive to vaginal infection with low doses of HSV-2 (Ashkar and Rosenthal, 2003). Also, as noted earlier (Section II.A on NKT development), SAP deficiency leads to a selective loss of NKT cells in mice and humans (Chung, et al., 2005; Nichols, et al., 2005; Pasquier, et al., 2005). In humans, SAP deficiency results in the X-linked lymphoproliferative (XLP) syndrome, in which patients are much more sensitive to lethal infection with Epstein-Barr virus (EBV), another member of the herpesvirus family. Thus, there is the indirect suggestion that NKT cells may be involved in the control of EBV infection.

\section{Role of type I NKT cells in autoimmunity}

1. ENDOCRINE DISEASES: DIABETES MELLITUS-In contrast to their likely direct effector role in some infectious diseases, type I NKT cells have been found to play a more 
regulatory role in autoimmunity, especially through their production of Th2 cytokines like IL-4 and IL-13. One of the best-studied examples is that of type I diabetes mellitus, in both NOD mice and humans. NOD mice that are prone to diabetes appear to have reduced numbers of NKT cells compared to other strains of mice (Godfrey et al., 1997; Gombert et al., 1996). Activation of the NKT cells still present in these mice with $\alpha$-GalCer prevented both the onset and recurrence of type I diabetes (Sharif et al., 2001). Also, reconstitution of their numbers by adoptive transfer of type I NKT cells into NOD mice led to protection by a mechanism dependent on both IL-4 and IL-10 (Baxter et al., 1997; Hammond et al., 1998), although the mechanism remains controversial (Wilson and Delovitch, 2003). Also, expression of a transgenic V $\alpha 14 \mathrm{~J} \alpha 18$ TCR in NOD mice protected them from diabetes, even though the diabetogenic T cell repertoire still developed (Lehuen et al., 1998), suggesting that the NKT cells prevent the effector mechanism of pancreatic islet destruction, rather than the induction of the anti-islet T cells. Finally, stimulation of type I NKT cells with an $\alpha$-GalCer homologue $\mathrm{C} 20: 2$ that skews the response more toward Th2 cytokines was found to effectively reduce and delay onset of diabetes in NOD mice (Forestier, et al., 2007). Thus, extensive evidence supports a regulatory role of type I NKT cells, especially through their production of Th2 cytokines, in control of diabetes in the NOD mouse model.

There is also indirect evidence in humans for a role for type I NKT cells in diabetes (Wilson and Van Kaer, 2003). For example, these cells were either less frequent or more skewed toward Th1 and away from Th2 cytokines in diabetes patients (Kukreja et al., 2002; Wilson et al., 1998). However, this correlation was at least partially called into question by studies showing extreme variability in numbers of type I NKT cells in human peripheral blood donors using a combination of CD1d tetramer staining and antibodies to V $\alpha 24$, which did not find such a correlation between NKT cell numbers and diabetes (Lee et al., 2002b).

2. NEUROLOGIC AND RHEUMATOLOGIC DISEASES-An $\alpha$-GalCer analogue that induces responses more skewed toward Th2 cytokines, called $\mathrm{OCH}$, has also been found to protect mice against the Th1/Th17-mediated experimental autoimmune encephalitis (EAE), a mouse model of multiple sclerosis (Miyamoto, et al., 2001; Oki et al., 2004). Moreover, in humans, a Th2 cytokine bias was observed in $\mathrm{CD}^{+}$(but not double negative) type I NKT cells in multiple sclerosis patients in remission, compared to multiple sclerosis patients in relapse or to healthy controls, suggesting that type I NKT cells may similarly play a regulatory role in human multiple sclerosis even without exogenous stimulation with glycolipids (Araki et al., 2003). Similarly, OCH treatment to induce a Th2 cytokine response from type I NKT cells could inhibit induction of collagen-induced arthritis in mice (Chiba et al., 2004). On the other hand, in EAE, type I NKT cells may have additional mechanisms to protect not involving Th2 cytokines, as observed in V $\alpha 14 \mathrm{~J} \alpha 18$ transgenic NOD mice (Mars et al., 2002) or in mice treated with $\alpha$-GalCer in which EAE was induced with myelin oligodendrocyte glycoprotein (MOG) (Furlan et al., 2003).

3. ASTHMA-One autoimmune disease in which type I NKT cells may play an effector role rather than a regulatory one, although still involving Th2 cytokine production, is asthma. The development of asthmatic allergen-induced airway hypersensitivity in mice was found to require type I NKT cells producing IL-4 and IL-13, even though the NKT cell-deficient mice had conventional Th2 cells capable of making these cytokines (Akbari et al., 2003). Moreover, the ability to induce airway hypersensitivity could be restored in $\mathrm{J} \alpha 18^{-1-}$ mice by adoptive transfer of type I NKT cells making Th2 cytokines, and could also be restored in CD1 ${ }^{-/-}$mice by administration of IL-13 (Akbari, et al., 2003). Furthermore, stimulation of type I NKT cells with $\alpha$-GalCer induced airway hypersensitivity even in class II MHC deficient mice that lack conventional $\mathrm{CD}^{+} \mathrm{T}$ cells that could produce Th2 cytokines (Meyer et al., 2006). Thus, there is strong evidence in mice that type I NKT cells play an essential effector role in asthma independent of conventional Th2 cells. Indirect evidence that type I NKT cells may play a 
similar role in human asthma comes from the findings that CD1d-tetramer-positive cells represent as much as $60 \%$ of the $\mathrm{CD}^{+} \mathrm{CD}^{+} \mathrm{T}$ cells in the lungs of patients with moderate or severe asthma (but not those with sarcoidosis), express the invariant V $\alpha 24$ TCR, and make Th2 cytokines (Akbari et al., 2006). Although such a high frequency was not observed in all cases (Thomas et al., 2006), nevertheless, the evidence seems overwhelming that type I NKT cells play an important pathogenic role in experimental models of asthma and are at least positioned to play a similar role in human asthma, where it is more difficult to prove cause and effect.

4. GRAFT-VERSUS-HOST DISEASE-Another syndrome related to but distinct from autoimmune disease is graft-versus-host-disease (GVHD) after bone marrow transplantation, and the related graft-versus-leukemia (GVL) effect in which grafted cells can eradicate leukemia cells. Interestingly, using $\mathrm{CD} 1 \mathrm{~d}^{-/-}$and $\mathrm{J} \alpha 18^{-/-}$mice and reconstitution of the latter with syngeneic type I NKT cells, it was found that type I NKT cells from the host can protect against GVHD, while preserving the desired GVL effect (Pillai et al., 2007). In this case, although the mechanism is not clear, it is possible that NKT cells act as effector cells as well, targeting donor $\mathrm{T}$ cells mediating GVHD.

5. ANTERIOR CHAMBER-ASSOCIATED IMMUNE DEVIATION-Although anterior chamber-associated immune deviation (ACAID) is not an autoimmune disease, the role of type I NKT cells in induction of tolerance is well described in the antigen-specific peripheral tolerance induced by inoculating an antigen into the anterior chamber of the eye (Nowak and Stein-Streilein, 2007; Sonoda et al., 1999). CD4 ${ }^{+}$type I NKT cells have been shown to be recruited to the spleens (marginal zone) of antigen-inoculated mice by MIP-2 secreted by tolerogenic $\mathrm{F} 4 / 80^{+}$macrophages that migrated from the anterior chamber (Faunce et al., 2001; Nowak and Stein-Streilein, 2007). Those recruited CD4 ${ }^{+}$type I NKT cells are activated by the macrophages by CD1d antigen presentation, and produce RANTES to recruit more $\mathrm{F} 4 / 80^{+}$macrophages and IL-10 to induce differentiation of antigen-specific regulatory $\mathrm{CD}^{+}$ T cells in the splenic marginal zone (Nowak and Stein-Streilein, 2007; Sonoda et al., 2001; Sonoda and Stein-Streilein, 2002). It was also reported that type I NKT cells are necessary for long-term (12 week) corneal allograft survival as survival was reduced from $50 \%$ for wild type to $0 \%$ for $\mathrm{J} \alpha 18 \mathrm{KO}$ mice lacking type I NKT cells (Sonoda et al., 2002).

\section{E. Type I NKT cells in tumor immunity and immunotherapy 1. MURINE TUMOR MODELS}

a. Role in Treatment with Exogenous $\alpha$-GalCer or IL-12: In contrast to the role of type I NKT cells in autoimmunity, which is largely mediated by production of Th2 cytokines like IL-4 and IL-13 and which is mostly of a regulatory nature, except in asthma, in the case of tumor immunity, the type I NKT cell has been found to play primarily a protective role dependent on its ability to make the Th1 cytokine interferon- $\gamma$ (Berzofsky and Terabe, 2008; Smyth and Godfrey, 2000). This was initially appreciated when it was found that $\alpha$-GalCer, previously found to have anti-tumor activity (Kobayashi et al., 1995; Morita et al., 1995;

Motoki et al., 1995), was a very potent agonist for type I NKT cells (Kawano, et al., 1997). This observation led to a number of studies showing the ability of $\alpha$-GalCer to protect against tumors in mice. Syngeneic DCs pulsed with $\alpha$-GalCer were able to treat week-old established liver metastases of the B16 melanoma (Toura et al., 1999). More recent studies show that a Cglycoside analogue of $\alpha$-GalCer, skewed more toward an interferon- $\gamma$ response, was even more effective against melanoma metastases in mice (Schmieg, et al., 2003). Chronic administration of $\alpha$-GalCer could even prevent formation of spontaneous autologous tumors in mice treated with methylcholanthrene or in mice transgenic for the Her-2/neu oncogene or deficient in the p53 tumor suppressor (Hayakawa et al., 2003). Moreover, even without $\alpha$-GalCer or other exogenous stimulation, type I NKT cells were found to be necessary for IL-12-mediated tumor rejection, as this did not occur in J $\alpha 18^{-/-}$mice lacking type I NKT cells (Cui, et al., 1997). The 
dependence of IL-12 efficacy on NKT cells is probably dose-dependent, as the efficacy of IL-12 was NKT cell-dependent at low doses of IL-12 but not at higher doses (Nakui et al., 2000; Park et al., 2003; Smyth et al., 2000a; Takeda et al., 2000a). Thus, NKT cells were found to be mediators of the protection induced both by $\alpha$-GalCer and by exogenous IL- 12 .

b. Spontaneouos Role in the Absence of Exogenous Agents: Even in the absence of exogenous stimulation with $\alpha$-GalCer or IL-12, protection against spontaneous methylcholanthrene-induced tumors in mice was found to be dependent on type I NKT cells as shown by the absence of this protective effect in $\mathrm{J} \alpha 18^{-/-}$mice (Smyth et al., 2000b). The role of NKT cells in spontaneous protection against methylcholanthrene-induced sarcomas was confirmed by reconstitution of the protected wild-type phenotype by adoptive transfer of purified liver NKT cells (Crowe et al., 2002). In that model, it was particularly the CD4 negative (CD4 ${ }^{-} \mathrm{CD}^{-}$double negative) subset of liver NKT cells that protected, whereas NKT cells from thymus and spleen were less protective, indicating that not all subsets or origins of type I NKT cells are equally protective (Crowe, et al., 2005). Another case in which type I NKT cells were implicated in protection in the absence of treatment with either $\alpha$-GalCer or IL-12 was the case of pulmonary metastases produced by i.v. inoculation of the methylcholanthreneinduced BALB/c sarcoma CMS5m (Nishikawa et al., 2003). In this model, J $118^{-/-}$mice lacking type I NKT cells had more lung metastases, and this greater susceptibility could be reversed by adoptive transfer of $\alpha$-GalCer/CD1d tetramer-positive type I NKT cells. Moreover, the suppression of tumor immunity by $\mathrm{CD} 4{ }^{+} \mathrm{CD} 25^{+} \mathrm{T}$ regulatory (Treg) cells induced by injection of a SEREX-defined tumor antigen seemed to depend on the reduction in the number of type I NKT cells in the lungs of these mice by the Treg cells, which could also be caused by adoptive transfer of such Treg cells (Nishikawa, et al., 2003). Thus, it appears not only that type I NKT cells can contribute to spontaneous tumor immunosurveillance, but also that one mechanism by which $\mathrm{CD} 4^{+} \mathrm{CD} 25^{+}$Treg cells suppress tumor immunity is by decreasing the numbers of type I NKT cells (see also Section IV.B below). In yet another tumor model, the HPV16 E6 and E7-expressing TC1 tumor, protection against early tumors by transfer of cells from E7-immunized C57BL/6 mice depended on transfer of not only antigen-specific CD8 ${ }^{+}$ T cells but also type I NKT cells (Stewart et al., 2003).

c. Mechanisms of Protection: Even in tumor immunity, NKT cells appear to work primarily through their effect on other cells such as NK cells and $\mathrm{CD}^{+} \mathrm{T}$ cells, not by acting as direct anti-tumor effector cells, although NKT cells are capable of lysing tumor cells (Fig. 1). The protection against methylcholanthrene-induced tumors by transfer of type I NKT cells was found to depend on interferon- $\gamma$ expression, but not perforin expression, by the type I NKT cells, and on activation of $\mathrm{CD}^{+}$and NK effector cells and their ability to make perforin (Crowe, et al., 2002). Further, the lesser protective effect of thymic as opposed to liver NKT cells appeared related to their greater production of IL-4 because the tumor immunity was greater when the thymic NKT cells transferred came from IL-4 ${ }^{-/}$mice (Crowe, et al., 2005). In these mouse models, both perforin and interferon- $\gamma$ were necessary for protection (Street et al., 2001) and both NKT cells and NK cells were necessary for $\alpha$-GalCer anti-tumor activity, whereas after high dose IL-12 therapy, only NK but not NKT cells were necessary (Smyth et al., 2001). Moreover, using NK-deficient, NKT-deficient, and lymphocyte-deficient $\left(\mathrm{Rag}^{-/-}\right)$ mice, it was shown that the reconstitution of $\alpha$-GalCer-mediated protection against tumors depended on sequential production of interferon- $\gamma$ by NKT cells and then by NK cells (Smyth et al., 2002). NKT cells rapidly activate NK cells (Carnaud et al., 1999). The activation of NK cells by NKT cells appears to depend on IL-2 as well as interferon- $\gamma$ at least in humans (Metelitsa et al., 2001). NK induction by NKT cells can also be augmented for tumor immunotherapy by provision of IL-21 (Smyth et al., 2005). Besides activating NK cells, the interferon- $\gamma$ plays a role in inhibiting tumor angiogenesis (Hayakawa et al., 2002). Thus, overall, it is likely that the NKT cells serve to promote tumor immunity by other effector cells, both NK cells and $\mathrm{CD}^{+} \mathrm{T}$ cells, through their production of interferon- $\gamma$ and their ability to 
induce DC production of IL-12, rather than any direct effector function against the tumor by the NKT cells themselves. However, they can mediate direct killing of tumor cells as well (Metelitsa, et al., 2001). Nevertheless, in the case of cancer, as in autoimmune disease, the primary role of NKT cells is regulatory, but in this case promoting rather than inhibiting immunity, based on a Th1 cytokine profile rather than a Th2 cytokine profile.

The role of type I NKT cells in activating DCs to make IL-12 and other cytokines (such as IL-15) may be as important as their production of interferon- $\gamma$. As noted earlier, NKT cells could activate DCs to make IL-12, which contributed to their anti-tumor effect, and $\alpha$-GalCerpulsed DC could induce a protective response against tumor (Toura, et al., 1999). IL-12 was found to play an integral role in the anti-tumor immunity induced by $\alpha$-GalCer, as $\alpha-\mathrm{GalCer}$ induced DC production of IL-12 in a mechanism dependent on NKT cell activation and direct interaction of NKT cells with DCs through CD40L-CD40 binding (Kitamura et al., 1999). This induction of IL-12 by DCs was required for $\alpha$-GalCer to induce interferon- $\gamma$ production by type I NKT cells. Conversely, the $\alpha$-GalCer also induced upregulation of the IL-12 receptor on NKT cells (Kitamura, et al., 1999). Further, tumor rejection was dependent on type I NKT cells primarily in tumors in mice in which rejection depended on endogenous IL-12 production. In addition to the IL-12 production, it was shown that NKT cells could induce maturation of DCs to make them more effective at activating conventional $\mathrm{CD} 4^{+}$and $\mathrm{CD} 8^{+}$adaptive $\mathrm{T}$ cell responses (Fujii et al., 2003b). Indeed, $\alpha$-GalCer pulsed DCs were more effective than free $\alpha$ GalCer possibly because the pulsed DCs induced a more interferon- $\gamma$-skewed cytokine profile and a response that was more prolonged than that induced by free $\alpha$-GalCer (Fujii et al., 2002), which tended to anergize the NKT cells after first activating them (Fujii, et al., 2002), or to skew them toward a Th2 cytokine profile (Burdin et al., 1999). Also, $\alpha-$ GalCer or $\alpha-C$ GalCer could substitute for agonist anti-CD40 (an activator of DC) in a combination therapy with anti-4-1BB and anti-DR5 to cause tumor rejection in mice (Teng et al., 2007). For these reasons, therapy with DC pulsed with $\alpha$-GalCer may be more effective than therapy with free $\alpha$-GalCer.

d. Therapeutic Approaches: Based on these concepts, studies have been carried out showing that administration of dying irradiated tumor cells along with $\alpha$-GalCer led to uptake of tumor cell antigens by DC that were activated by the $\alpha$-GalCer to present the tumor antigens more effectively to conventional $\mathrm{CD}^{+}$and $\mathrm{CD}^{+} \mathrm{T}$ cells (Liu et al., 2005a). This immunization approach led to induction of specific $T$ cells that protected against both a lymphoma and a plasmacytoma and could transfer protection to another host. Even tumor cells themselves pulsed with $\alpha$-GalCer could be injected to induce potent anti-tumor immunity in several tumor models (including the B16 melanoma, the J558 plasmacytoma, the WEHI3B myelomonocytic leukemia and the EL4 thymoma) involving NKT-cell and NK-cell-mediated lysis of tumor cells and crosspresentation of the tumor antigens by host DCs activated by NKT cells (Shimizu et al., 2007a; Shimizu et al., 2007b). The protection was specific for each tumor and did not provide crossprotection against the other tumors. Even B cells pulsed with $\alpha$-GalCer could induce anti-tumor immunity (Chung et al., 2006; Kim et al., 2008). Also, $\alpha$-GalCer could be used as an intranasal vaccine adjuvant to induce protective immunity against influenza, and against an ovalbumin-transfected thymoma tumor EG7 in mice (Ko et al., 2005). As a vaccine adjuvant, $\alpha$-GalCer could also overcome oral tolerance by upregulation of costimulatory molecules on DCs (Chung et al., 2004). Furthermore, type I NKT cell lines could be generated by chronic stimulation in vitro, and then adoptively transferred to confer protection against B16.F10 melanoma experimental lung metastases (Molling et al., 2008).

e. Suppression of Immunity by Type I NKT cells: Although most studies on type I NKT cells have shown that they play a protective role, type I NKT cells were also shown to suppress natural immunosurveillance against a CD1d-transfected RMA/S T lymphoma (Renukaradhya et al., 2006). IL-13 production was significantly higher in wild-type mice challenged with the 
CD1d-transfected RMA/S compared to type I NKT cell-deficient mice whereas IFN- $\gamma$ and GM-CSF levels were significantly higher in tumor-challenged type I NKT cell-deficient mice than in wild-type mice. However, significant type I NKT cell-mediated suppression of tumor immunity was not seen when parental RMA/S cells, which express a low level of CD1d, were used (Renukaradhya, et al., 2006). Also suppression of tumor-antigen specific CD8 ${ }^{+} \mathrm{T}$ cells by $\mathrm{CD}^{+}$human type I NKT cells was reported when stimulated with $\alpha$-GalCer (Osada et al., 2005). Either IL-4, IL-5 or IL-10 was necessary for the suppression. In both cases, the suppression seemed to be mediated by Th2 cytokine production by type I NKT cells.

\section{HUMAN TUMORS}

a. Observational Studies: In humans as well, there is evidence for a role of type I NKT cells in tumor immunity. In vitro, human NKT cells could be expanded and skewed toward interferon- $\gamma$ production by autologous DCs pulsed with $\alpha$-GalCer (van der Vliet et al., 2003). Also, in vitro, $\alpha$-GalCer could activate NKT cells to induce human tumor lysis by human NK cells (Ishihara et al., 2000). In vivo, a defect in NKT cell function to produce interferon- $\gamma$ was observed in progressive malignant multiple myeloma patients, in both peripheral blood and the tumor bed, but was not seen in patients with non-progressive myeloma or premalignant gammopathy (Dhodapkar et al., 2003). It was hypothesized that since fresh myeloma cells express CD1d, they could be killed by NKT cells, but they might also anergize them. Decreases in numbers of type I NKT cells, in their ability to expand ex vivo, and in their production of interferon- $\gamma$ (with a shift toward IL-4) was also seen in prostate cancer patients (Tahir et al., 2001). Statistically significantly $(p=0.0001)$ lower numbers of peripheral blood NKT cells were found in patients with a number of solid tumors compared to healthy controls (Giaccone et al., 2002). V $\alpha 24 \mathrm{~V} \beta 11$ type I NKT cells were also decreased in number and in responsiveness to $\alpha$-GalCer in 109 patients with a variety of solid tumors compared to healthy controls (Crough et al., 2004). Other studies also found a decrease in proliferation or interferon- $\gamma$ production by type I NKT cells from cancer patients (Fujii et al., 2003a; Yanagisawa et al., 2002). A recent study found that the decreased function of type I NKT cells in cancer patients with low NKT cell numbers may be related to their interaction with CD1d-expressing circulating myeloid DCs, as such patient DCs could also suppress Th1 cytokine production by NKT cells from healthy blood donors (van der Vliet et al., 2008). The defect could be reversed by IL-12 or neutralization of TGF- $\beta$, but was exacerbated by neutralization of IL-10. On the other hand, defects in NKT cells were not found in glioma patients, and the NKT cells from the glioma patients could be expanded in vitro with $\alpha$-GalCer and could kill glioma cells in vitro (Dhodapkar et al., 2004). Importantly, in primary colorectal carcinomas, high infiltration of the tumors with Va24-positive type I NKT cells was an independent prognostic factor for both overall survival and disease-free survival (Tachibana et al., 2005). Likewise, low circulating levels of type I NKT cells was an independent predictor of poor overall survival and diseasefree survival in patients with head and neck squamous cell carcinoma (Molling et al., 2007).

b. Clinical Therapeutic Trials: Based on this type of evidence, clinical trials were undertaken to treat cancer patients with $\alpha$-GalCer itself or autologous DCs pulsed with $\alpha$-GalCer. In a study of patients with various solid tumors given $\alpha$-GalCer i.v. on days 1, 8 and 15 of a 4-week cycle, no toxicity was observed, and increased cytokine levels (TNF $\alpha$ and GM-CSF) were seen in patients who had higher pre-treatment levels of NKT cells in their blood (Giaccone, et al., 2002). In that study, the pharmacokinetics of $\alpha$-GalCer fit a 3-compartment model and was linear over the dose range given $\left(50-4800 \mu \mathrm{g} / \mathrm{m}^{2}\right)$ (Crul et al., 2002). In the first clinical trial with $\alpha$-GalCer-pulsed autologous DCs in 4 metastatic cancer patients, subjects received two infusions of DCs i.v. and two infusions intradermally (Okai et al., 2002). No adverse effects were seen, and V $\alpha 24 \mathrm{~V} \beta 11$ expressing NKT cells were expanded by the treatment. In a followup publication by the same group, activation of NKT cells in the patients was found to lead to activation of other components of the innate and adaptive immune systems and to increases in 
serum interferon- $\gamma$ (Nieda et al., 2004). In another study, monocyte-derived mature DCs were pulsed with $\alpha$-GalCer and used to treat 5 patients with advanced cancer (Chang et al., 2005). The treatment was observed to increase NKT cell numbers in all patients detectable up to 6 months after treatment and to increase serum levels of IL-12 p40 and IP10, as well as increase cytomegalovirus-specific CD8 ${ }^{+} \mathrm{T}$ cells. In another phase I study, 11 patients with advanced or recurrent non-small cell lung cancer were given autologous DCs pulsed with $\alpha$-GalCer i.v., and several showed expansions of $\mathrm{V} \alpha 24^{+} \mathrm{NKT}$ cells, with no adverse effects seen (Ishikawa et al., 2005a). Ex vivo expansion of autologous type I NKT cells in six non-small cell lung cancer patients and reinfusion studied by the same group also showed increased numbers of NKT cells in the blood of patients and no adverse effects (Motohashi et al., 2006). However, in none of these trials with $\alpha$-GalCer, DCs pulsed with $\alpha$-GalCer, or adoptive transfer of autologous type I NKT cells, was any significant complete or partial remission of the cancer observed. The difference in the experience so far in humans from the more promising results in mice could relate to the lower numbers of type I NKT cells observed in humans compared to mice (Kronenberg, 2005) as well as their greater variability (noted earlier (Lee, et al., $2002 \mathrm{~b})$ ), or to the fact that the human patients had much more advanced cancer than the mice in which $\alpha$-GalCer therapy or prophylaxis was effective.

\section{TYPE II NKT CELLS}

\section{A. Characterization}

The existence of CD1d-restricted T cells without expression of the invariant V $\alpha 14 \mathrm{~J} \alpha 18$ TCR was first reported by Cardell et al. in 1995 (Cardell et al., 1995). They examined the TCR usage of CD1d-autoreactive CD4 ${ }^{+} \mathrm{T}$ cell hybridomas of class II MHC deficient mice and surprisingly found that the majority of them do not express the "classical" V $\alpha 14 \mathrm{~J} \alpha 18$ TCR $\alpha$ chain but had a heterogenous TCR repertoire. A similar observation of CD1d-autoreactive T cells with diverse TCR expression was made in mice immunized with a tumor expressing CD1d but neither class I nor class II MHC (Behar et al., 1999b). This NKT cell population is now called type II NKT cells (Godfrey, et al., 2004). Distinct from type I NKT cells, which are defined as a cell population expressing a unique TCR $\alpha$ chain, V $\alpha 14 \mathrm{~J} \alpha 18$, type II NKT cells are defined as the CD1d-restricted NKT cells that lack this TCR $\alpha$ (Table I). Therefore, they are likely to be a heterogenous cell population. In fact although they express diverse TCR $\alpha$ chains, some subsets express particular TCR $\alpha$ chains such as a V $\alpha 3.2 \mathrm{~J} \alpha 9$ and V $\alpha 8$ (Park et al., 2001). The diversity of TCRs is not well studied yet (Behar and Cardell, 2000). Similar to type I NKT cells, type II NKT cells are a mixture of both NK1.1 ${ }^{+}$and $\mathrm{NK} 1.1^{-}$populations and produce both Th1 (interferon- $\gamma$ ) and Th2 (IL-4) cytokines upon the stimulation with CD1d antigen presentation (Chiu, et al., 1999). Therefore, they are likely to have immunoregulatory functions similar to type I NKT cells.

Although type II NKT cells recognize antigens presented by CD1d, as they are defined, they seem to recognize a different set of antigens from a different cellular compartment (Brossay et al., 1998; Chiu, et al., 1999). CD1d has a tyrosine-based targeting motif in the cytoplasmic tail which gives it access to the endosomal compartment. When a panel of NKT cell hybridomas were tested for their reactivity to a fibroblast cell line transfected with either a wild-type CD1d gene with the targeting motif (CD1-WT) or a gene with the tail-deleted construct (CD1-TD), a panel of type I NKT cells lost their reactivity against the CD1-TD expressing cells compared to the CD1-WT transfectant (Chiu, et al., 1999). In contrast, a panel of type II NKT cells retained their reactivity against CD1-TD. This is also the case with freshly isolated NKT cells. Further, mice expressing CD1-TD lacking CD1-WT have a significantly reduced number of type I NKT cells but retain V $\alpha 3.2 \mathrm{~J} \alpha 9$ type II NKT cells, suggesting that different sets of antigens from different cell compartments are required for the development of type I and type II NKT cells in vivo (Brossay, et al., 1998; Chiu, et al., 1999; Chiu et al., 2002). This idea was further proven when cis-tetracosenoyl sulfatide (sulfatide), which is a self glycolipid abundant 
in myelin sheath fluid, was found to be recognized by a fraction of type II NKT cells. Jahng et al. showed that type I NKT cells in mouse spleen that can be stained with CD1d-tetramer loaded with $\alpha$-GalCer were not stained with CD1d-tetramer loaded with sulfatide and vice versa (Jahng, et al., 2004). The crystal structure of sulfatide-CD1d complex was recently reported (Zajonc et al., 2005). The frequency of type II NKT cells stained by CD1d-tetramer loaded with sulfatide was $1 / 5$ of the frequency of type I NKT cells in the spleen. However, V $\alpha 3.2$ V $\beta 9$ type II NKT cell hybridomas do not recognize sulfatide. This evidence suggests that type II NKT cells survey a distinct set of glycolipid antigens from those detected by type I NKT cells to complement the function of type I NKT cells for immunological surveillance.

It is also suggested by using class II MHC deficient mice that the majority of $\mathrm{CD} 4^{+}$type II NKT cells are NK1.1 $1^{-}$, in contrast to $\mathrm{CD} 4^{+}$type I NKT cells, the majority of which express NK1.1 (Park, et al., 2001). The expression level of TCR/CD3 on type II NKT cells is not well defined yet.

In humans, the ratio between type II and type I NKT cells seems to be higher than in mice (Kenna et al., 2003). Surprisingly, some human type II NKT cells, which do not express an invariant V $\alpha 24 \mathrm{~J} \alpha 18 \mathrm{TCR}$ chain, were reported to recognize the $\alpha$-GalCer-CD1d complex (Gadola, et al., 2002). Those $\alpha$-GalCer-reactive type II NKT cells were either CD $4^{+}$or $\mathrm{CD} 8 \alpha \beta^{+}$, and a significant proportion of the type II NKT cells express a V $\beta 11$ chain. They seem to have lower TCR binding affinity to the $\alpha$-GalCer-CD1d complex compared to type I NKT cells. Many of them did not produce IL- 4 upon $\alpha$-GalCer stimulation but did produce IL-2, interferon- $\gamma$ and IL-13.

A significant disadvantage for characterization of type II NKT cells is the lack of knowledge of specific markers for this cell population. Although recently sulfatide and its analog lysosulfatide were reported to be recognized by a fraction of mouse type II NKT cells (Roy et al., 2008), and PPBF (phenyl 2,2,4,6,7-petamethyldihydrobenzofuran-5-sulfonate) (Van Rhijn et al., 2004) to be recognized by human type II NKT cells, they have not served as an easy-touse tool to characterize type II NKT cells as $\alpha$-GalCer has served for the characterization of type I NKT cells. Therefore, although now a TCR transgenic mouse with a V $\alpha 3.2 \mathrm{~V} \beta 9$ TCR rearrangement cloned from one type II NKT cell hybridoma is available (Skold et al., 2000), compared to the knowledge of type I NKT cells, that of type II NKT cells is so far very limited.

\section{B. Type II NKT cells in the regulation of autoimmune diseases and infectious diseases}

Although the knowledge of type II NKT cells is very limited, so far, similar to type I NKT cells, this type of NKT cells also has immunoregulatory properties in different settings.

1. MULTIPLE SCLEROSIS-The only glycolipid antigen of natural origin to be shown to stimulate type II NKT cells is sulfatide (Jahng, et al., 2004; Roy, et al., 2008; Zajonc, et al., 2005). This glycolipid species is enriched in myelin sheath fluid and has been shown to be presented by multiple isoforms of CD1 in humans (Shamshiev et al., 2002). EAE is a mouse model of multiple sclerosis, which is characterized by inflammation and demyelination in the central nervous system infiltrated with conventional $\mathrm{T}$ cells. It has been reported that patients with multiple sclerosis have an increased frequency of self glycolipid-reactive $\mathrm{T}$ cells in the peripheral blood (Shamshiev et al., 1999). As a T cell subset which recognizes glycolipid antigens, NKT cells have been considered to play a role in controlling the disease. In an EAE model in mice, interferon- $\gamma$-secreting sulfatide-reactive cells, which do not secret IL-4, were increased in the central nervous system during the disease (Jahng, et al., 2004). However, treating mice with sulfatide at the time of disease induction elicited sulfatide-reactive type II NKT cells secreting both IL-4 and interferon- $\gamma$. This treatment also increased IL-4 producing T cells specific for MOG peptide and prevented disease onset in wild-type mice but not in $\mathrm{CD}_{1} \mathrm{~d}^{-/-}$mice. Thus, type II NKT cells suppress EAE. 
2. TYPE I DIABETES-As described above (Section II.D), a role of type I NKT cells in controlling type I diabetes, a T cell-mediated autoimmune disease, is well studied by using NOD mice (Wilson and Delovitch, 2003). NOD mice overexpressing a TCR cloned from a type II NKT cell, V $\alpha 3.2 \mathrm{~V} \beta 9$, do not have diabetes but still develop insulitis, suggesting a suppression of the disease by the clone of type II NKT cells (Duarte et al., 2004). In a model of NODscid with transferred diabetogenic spleen cells from NOD female mice, type II NKT cells expressing $\mathrm{V} \alpha 3.2 \mathrm{~V} \beta 9$ from TCR transgenic mice were shown to delay disease onset when they were co-transferred.

3. ULCERATIVE COLITIS-Ulcerative colitis is a form of inflammatory bowl disease in which $\mathrm{Th} 2$ responses including antibody production are interpreted to play a major role in causing superficial damage of the mucosal tissue. In patients with ulcerative colitis, type II NKT cells from the lamina propria produce IL-13, a Th2 cytokine, upon the stimulation by CD1d (Fuss et al., 2004). The IL-13 seems to augment cytotoxicity of CD4 ${ }^{+} \mathrm{NKT}$ cells against CD1d-expressing epithelial cells, and is a critical element in the pathogenesis of the disease.

4. GRAFT-VERSUS-HOST DISEASE-Bone marrow transplantation is an effective treatment modality for certain blood cancers. However, a downside of this treatment is GVHD, which causes destruction of host tissues by engrafted lymphocytes. Bone marrow is a NKT cell-enriched organ in the body. As immunoregulators, NKT cells have been interpreted to contribute to control GVHD and graft-vs-tumor response (Haraguchi et al., 2005; Kim et al., 2007; Lan et al., 2003; Lan et al., 2001; Pillai, et al., 2007). In mouse bone marrow transplant experiments, both type I and type II NKT cells seem to contribute to regulation of different immunological responses by the engrafted lymphocytes. By comparing the ability of bone marrow cells from IL-4 ${ }^{-/-}$, IFN- $\gamma^{-/-}, \mathrm{J} \alpha 18^{-/-} \mathrm{IL}-4^{-/-}, \mathrm{J} \alpha 18^{-/-} \mathrm{IFN}-\gamma^{-/}$and $\mathrm{CD}^{-/-}$mice, type II NKT cells in the donor were shown to suppress GVHD. In this study, both IFN- $\gamma$ and IL-4 from type II NKT cells were critical for controlling GVHD by inducing apoptosis of donor lymphocytes by IFN- $\gamma$ through the expression of Fas-L and inducing immune deviation by IL-4 (Kim, et al., 2007). Interestingly, in comparison with Section II.D.4 above, it is donor type II NKT cells but host type I NKT cells that protect against GVHD.

In humans, the majority of CD1d-reactive cells in the bone marrow are type II NKT cells. These type II NKT cells in bone marrow of healthy donors show a Th2-biased cytokine profile and suppress the mixed lymphocyte response (MLR) (Exley et al., 2001).

5. SYSTEMIC LUPUS ERYTHEMATOSUS-Systemic lupus erythematosus (SLE) is a severe autoimmune disease characterized by anti-nuclear autoantibodies, immune complex disease, and multiorgan tissue injury. In human patients, the disease inversely correlated with the number of type I NKT cells in peripheral blood (Kojo et al., 2001; Sumida et al., 1995; van der Vliet et al., 2001). In a mouse model using (NZBxNZW)F1 mice, the outcome of type I NKT cell-activation may differ depending on the age of the mice due to a different activation status of type I NKT cells at different ages (Forestier et al., 2005; Yang et al., 2003; Zeng et al., 1998). The role of type II NKT cells in the disease is not clear yet. However, there is a study using two different lines of TCR transgenic mice expressing a Va4.4V $\beta 9$ TCR, cloned from $\mathrm{CD} 4^{-} \mathrm{CD} 8^{-} \mathrm{CD} 1 \mathrm{~d}$-autoreactive $\mathrm{T}$ cells of BALB/c mice, expressed exclusively on either CD4/CD8 single positive $T$ cells or double negative $T$ cells, that suggested a potential involvement of type II NKT cells (Zeng, et al., 1998). The injection of bone marrow of the transgenic mice with the TCR expressed only on CD4/CD8 single positive T cells into irradiated nude mice induced lupus, including autoantibody production and ascites. Induction of B cell-antibody production by the CD1d-reactive transgenic T cells can be suppressed by CD1d-blockade. In contrast, the injection of bone marrow from the mice expressing transgenic TCR only on CD4/CD8 double negative T cells did not induce the disease. These data suggest 
that CD4/CD8 single positive but not double negative type II NKT cells may contribute to the disease.

6. HEPATITIS-NKT cells are enriched in the liver at least in mice. In mice approximately $30 \%$ of the resident T cells in livers are NKT cells. In Concanavalin A-induced experimental hepatitis, type I NKT cells play a pivotal role in pathogenesis (Diao et al., 2004; Dieli et al., 2000; Kaneko et al., 2000; Takeda et al., 2000b). IL-4 produced by type I NKT cells induces expression of Fas-L, which mediates direct toxicity by activated type I NKT cells in an autocrine fashion (Kaneko, et al., 2000; Takeda, et al., 2000b). Recently, it was found that sulfatide-reactive type II NKT cell activation induces anergy of pathogenic type I NKT cells (Halder et al., 2007). The type II NKT cells accumulated in the liver after sulfatide injection. They recruited type I NKT cells to the liver through plasmacytoid DCs (pDCs) producing IL-12 and MIP-2. These pDCs induced anergy of type I NKT cells, which prevented the disease.

Viral-induced hepatitis is a type of immune disease since viral infection itself does not cause liver injury, but the immune reaction to the virus causes immunopathology. In a model of virusinduced hepatitis, an HBV-Env transgenic mouse model, splenic NK1.1 ${ }^{+} \mathrm{T}$ cells that do not bind to $\alpha$-GalCer loaded CD1d-tetramer were shown to mediate liver injury when they were transferred into HBV-Env transgenic mice lacking T cells (Baron et al., 2002). Expression of CD1d in the recipient and of $\mathrm{NKG} 2 \mathrm{D}$ on the $\mathrm{NK} 1.1^{+} \mathrm{T}$ cells are necessary for the liver injury (Vilarinho et al., 2007). In this system, neither type I NKT cells nor NK cells seem to play a major role. Thus, type II NKT cells seem to directly mediate pathogenesis.

In chronic HCV-infected patients, the frequency of type II NKT cells is higher than that of type I NKT cells (Exley et al., 2002). The type II NKT cells in the liver have a Th1 skewed cytokine profile compared to peripheral blood T cells from the same patients and showed strong lytic activity against CD1d expressing hepatocytes, suggesting a potential pathogenic function of type II NKT cells in the liver of virus-induced hepatitis, which is consistent with the result from the mouse HBV model.

7. PARASITE INFECTION-In mouse parasite infection models, type II NKT cells seem to play opposite roles in infections of the protozoan intracellular parasite, Trypanosoma, and the metazoan extracellular parasite, Schistosoma. Upon Trypanosoma infection, CD1d ${ }^{-1-}$ mice lacking both types of NKT cells show very mild inflammation whereas $\mathrm{J} \alpha 18^{-/-}$mice lacking type I NKT cells but retaining type II NKT cells have massive inflammation in the spleen, liver and skeletal muscle tissues (Duthie, et al., 2005). These results suggest a proinflammatory role of type II NKT cells and anti-inflammatory role of type I NKT cells in trypanosomiasis.

In schistosomiasis, NKT cells do not affect the early stage (within 3 weeks of infection) of infection before the parasites lay eggs (Mallevaey, et al., 2007). During the acute phase (7-12 weeks of infection), CD1 $\mathrm{d}^{-/-}$mice mount a more Th1 skewed immune response against egg antigen, which may contain glycoconjugates presented by CD1d (Faveeuw, et al., 2002), than wild-type mice. In contrast, compared to wild-type mice, $\mathrm{J} \alpha 18^{-/-}$mice mount a Th2 skewed immune response against egg antigen and show significantly enhanced granuloma formation, a major cause of pathogenesis of the infection. Thus, in contrast to Trypanosome infection, type I NKT cells induce a Th1 type immune response and type II NKT cells induce a Th2 type immune response in schistosomiasis responsible for some of the immunopathology. However, in both diseases, type II NKT cells contribute to the immunopathology.

\section{Type II NKT cell regulatory role in tumor immunity}

1. TYPE II NKT SUPPRESSION OF TUMOR IMMUNOSURVEILLANCE AND RESOLUTION OF THE PARADOX-Given the fact that many studies have shown that NKT cells enhance tumor immunity, it was a quite surprise and seemingly paradoxical that 
NKT cells potentially suppress tumor immunity (Moodycliffe et al., 2000; Terabe et al., 2000). In a mouse tumor model with an immunogenic fibrosarcoma, the 15-12M tumor cell line, in which subcutaneous tumors grow-regress-recur in syngeneic BALB/c mice, depletion of $\mathrm{CD}^{+}{ }^{+}$cells in vivo protected mice from tumor recurrence, indicating $\mathrm{CD} 4^{+} \mathrm{T}$ cell-mediated suppression of $\mathrm{CD}^{+} \mathrm{T}$ cell-mediated tumor immunity (Matsui et al., 1999). $\mathrm{CD} 4^{+} \mathrm{CD} 25^{+}$ regulatory $\mathrm{T}$ cells (Treg cells) do not seem to play a role since anti-CD25 treatment did not have any impact on tumor growth (Terabe et al., 2005). CD1d ${ }^{-1-}$ mice were resistant to tumor recurrence, indicating that NKT cells are the suppressors (Terabe, et al., 2000). To further characterize these regulatory NKT cells, a study was conducted to compare susceptibility of two different NKT cell deficient mice, $\mathrm{J} \alpha 18^{-/-}$and CD $1 \mathrm{~d}^{-/-}$, in five BALB/c tumor models, 15-12RM, CT26 colon carcinoma lung metastasis, CD26-L5 colon carcinoma subcutaneous, 4T1 mammary carcinoma, and CT26 subcutaneous models (Terabe, et al., 2005). Except in the CT26 subcutaneous tumor model (in which $\mathrm{CD} 4^{+} \mathrm{CD} 25^{+} \mathrm{T}$ regulatory cells dominate), $\mathrm{CD}_{1 \mathrm{~d}}{ }^{-/-}$mice were resistant to tumor growth, whereas $\mathrm{J} \alpha 18^{-/-}$mice behaved very similarly to wild-type mice. These results implied that in four different tumor models, between two types of NKT cells, type II NKT cells, present in $\mathrm{J} \alpha 18^{-/-}$mice but lacking in CD $1 \mathrm{~d}^{-/-}$mice, were sufficient to suppress tumor immunosurveillance (Terabe, et al., 2005). However, in the CT26 lung metastasis model, in which tumor growth can be assessed in a relatively quantitative fashion by counting nodules in the lungs, tumors seem to grow faster at an early stage of tumor growth in $\mathrm{J} \alpha 18^{-/-}$mice than in wild-type mice (Ambrosino et al., 2007). These results suggested that type II NKT cells existing in wild-type and $\mathrm{J} \alpha 18^{-/-}$mice are suppressive, whereas type I NKT cells lacking in $\mathrm{J} \alpha 18^{-/-}$and CD $1 \mathrm{~d}^{-/-}$mice promote tumor immunity, providing a possible resolution of the paradox. However, this hypothesis was not fully tested, since there are no type II NKT cell deficient mice because of the lack of any known type II NKT cell-specific marker. Similar observations of opposite roles of type I and type II NKT cells were found in all four different mouse tumor models. Recently, a similar observation was reported in the NSO B cell lymphoma tumor system in BALB/c mice (Renukaradhya et al., 2008). In a RENCA renal cell carcinoma model, anti-tumor effects of a combination of IL-12 and IL-18 were increased in CD1 $\mathrm{d}^{-1-}$ mice (Subleski et al., 2006). In a B16 melanoma model in the C57BL/6 strain, CpG oligodeoxynucleotide showed significant reduction of tumor burden in $\mathrm{CD}^{-/-}$mice but not in wild-type and $\mathrm{J} \alpha 18^{-/-}$mice (Sfondrini et al., 2002), consistent with an immunosuppressive role of type II NKT cells, although this was not suggested in the publication. On the other hand, in a tumor model using the MCA-1 methylcholanthrene induced spontaneous fibrosarcoma cell line, both $\mathrm{CD} 1^{-/-}$and $\mathrm{J} \alpha 18^{-/-}$mice were more susceptible to the tumor (Crowe, et al., 2002). Thus, the strength of suppression by type II NKT cells may differ among different types of tumors, and in the MCA-1 model, the primary impact of knocking out CD1d is the loss of type I NKT cell-mediated protection. This may also be a reflection of different expression patterns of glycolipid antigens presented by CD1d among tumors, since tumor cell lines expressing CD1d can stimulate different type I and type II NKT cell hybridomas (Gumperz, et al., 2000).

Although these studies comparing two different NKT cell-deficient mice suggested a resolution to the paradoxical observations on the opposing roles of NKT cells regulating tumor immunity by implicating different biological functions of two NKT cell subsets, they could not directly prove this explanation. Therefore, to test this hypothesis, Ambrosino et al conducted a study in which they actively stimulated one type of NKT cell or the other (Ambrosino, et al., 2007). In the CT26 lung metastasis model, activation of type I NKT cells by $\alpha$-GalCer or OCH almost completely abrogated tumors. In contrast, activation of type II NKT cells by sulfatide enhanced tumor burden. Although expression of sulfatides in the tumor cell lines has not been tested, human cancers are reported to express sulfatides (Roberts, 1986). Therefore, tumor-derived sulfatides may be involved in activating type II NKT cells in cancer-bearing animals or people. However, as mentioned above, because sulfatide is recognized by a fraction of type II NKT cells, the role of non-sulfatide reactive type II NKT cells such as $\mathrm{V} \alpha 3.2^{+} \mathrm{V} \beta 9^{+}$type II NKT 
cells in tumor immunity is not clear. Nevertheless these studies directly prove that type I and type II NKT cells mediate opposite effects in tumor immunity, and thus complete the resolution of the paradox.

In a mouse model of $\mathrm{UV}$ radiation-induced skin cancer, $\mathrm{CD} 1 \mathrm{~d}$-restricted $\mathrm{CD} 4^{+} \mathrm{DX} 5^{+} \mathrm{T}$ cells from UV-irradiated mice suppress tumor immunity. The suppression by the $\mathrm{CD} 4^{+} \mathrm{DX} 5^{+} \mathrm{T}$ cells is specific for a UV-induced tumor but not other types of tumors (Moodycliffe, et al., 2000). This may support the idea that type II NKT cells get activated by recognizing tumor derived glycolipids that may differ among tumors. With the fact that DX5 is not expressed on type I NKT cells (Pellicci et al., 2005), it is likely that the immunosuppressive NKT cell in the UVinduced tumor model is also a type II NKT cell. Overall, it seems that type II NKT cells suppress tumor immunity whereas type I NKT cells enhance it (Ambrosino, et al., 2008; Berzofsky and Terabe, 2008; Terabe and Berzofsky, 2007). As we will see below (Section IV.A.), they also cross-regulate each other.

\section{IDENTIFICATION OF A REGULATORY CIRCUIT AND THE ROLE OF}

CYTOKINES-A mechanism of immunosuppressive activity of type II NKT cells has been reported (Terabe, et al., 2000; Terabe et al., 2003a). In 15-12RM and CT26 lung metastasis models, $\mathrm{CD}^{+}$type II NKT cells seem to trigger an immunoregulatory pathway by producing IL-13, a Th2 cytokine. However, IL-13 cannot act directly on CTL to suppress immunosurveillance because the $\mathrm{CD} 8^{+} \mathrm{T}$ cells lack IL-13 receptors., Instead it was found that this IL-13 acts on myeloid lineage CD11 $\mathrm{b}^{+} \mathrm{Gr}-1^{+}$cells through the IL-4R $\alpha$-STAT6 signaling pathway to induce TGF- $\beta$ production, and the TGF- $\beta$ can directly suppress the T cell activation (Park et al., 2004; Terabe, et al., 2003a) (Fig. 2). Interference with any one of the four main components of the regulatory pathway-NKT cells, myeloid cells, IL-13 or TGF- $\beta$-can prevent tumor recurrence in one tumor model (Terabe, et al., 2000; Terabe, et al., 2003a) and reduce the number of metastases in another tumor model (Park, et al., 2004; Terabe, et al., $2003 a$ ). In addition to the induction of myeloid cells to make TGF- $\beta$, IL-13 may suppress tumor immunity also by inducing M2 macrophages (Sinha et al., 2005a; Sinha et al., 2005b). Thus, blockade of IL-13 may have therapeutic benefit through several mechanisms.

Because IL-13 shares its receptor with IL-4, in that the type II IL-4R consists of the IL-4R $\alpha$ and IL-13R 1 chains (McKenzie, 2000; Murata et al., 1998; Terabe et al., 2003b), it was not clear why IL-4 does not play a role in the regulatory pathway. Indeed, both cytokines signal through STAT6, which was found to be necessary for the suppression (Kacha et al., 2000; Ostrand-Rosenberg et al., 2002; Ostrand-Rosenberg et al., 2000; Terabe, et al., 2000). Recently it was reported that TNF- $\alpha$ acts as a co-factor for IL- 13 to induce TGF- $\beta$ production by myeloid cells through induction of IL-13R $\alpha 2$, a receptor that binds only to IL-13, to activate TGF- $\beta$ gene transcription via AP-1 (Fichtner-Feigl et al., 2005). Thus, not only blockade of either IL-13 or TGF- $\beta$, but also inhibition of TNF- $\alpha$ improves tumor immunity by interfering with the regulatory pathway (Fichtner-Feigl et al., 2008). This finding explains why IL-4 does not substitute for IL-13, as in addition to signaling through the type II IL-4R and STAT6, which respond to both IL-4 and IL-13, the uniquely IL13-specific receptor IL-13R $\alpha 2$ is also required. It should be noted that in the K7M2 osteosarcoma model, this regulatory pathway does not play a role in the immune suppression by NKT cells so NKT cells must mediate suppression by more than one mechanism (Terabe et al., 2006).

Although IL-13 is up-regulated and IFN- $\gamma$ is down-regulated when the regulatory pathway is active, the story is not a simple matter of Th1-Th2 balance. Activation of type I NKT cells by $\mathrm{OCH}$ induces a relatively Th2 skewed cytokine profile compared to the profile induced by $\alpha$ GalCer (Ambrosino, et al., 2008; Miyamoto, et al., 2001). However, OCH induced very strong protection in tumor challenged mice (Ambrosino, et al., 2007; Silk et al., 2004). On the other hand, sulfatide is shown to induce both Th1 and Th2 cytokine production by type II NKT cells 
(Jahng, et al., 2004). Therefore, although cytokines play important roles in type II NKT cell immune regulation, more detailed studies need to be conducted to dissect the effect of cytokine balance.

\section{INTERACTION OF NKT CELL SUBSETS WITH EACH OTHER AND OTHER CELL TYPES}

As a component of the immune system, NKT cells interact with other immune cells to form a network (Table II). As yet, there is only limited information on these interactions but they are the subject of much ongoing research.

\section{A. Interaction of type I and type II NKT cells}

As type I and type II NKT cells carry out opposing regulatory functions, and as we have learned in immunology that there are many dichotomies among immune cells that counteract each other, a direct interplay between type I and type II NKT cells can be anticipated. In fact they seem to counteract each other both in vitro and in vivo (Ambrosino, et al., 2007) (Fig. 3). Activation of type II NKT cells by sulfatide the suppresses proliferative response of type I NKT cells activated by $\alpha$-GalCer or OCH. This suppression is not due to a competition between sulfatide and $\alpha$-GalCer/OCH since stimulating NKT cells by mixing antigen presenting cells (APCs) pulsed separately with either glycolipid alone still gave a similar result. In vivo, in the 15-12RM subcutaneous and CT26 lung metastasis models, activating type II NKT cells by sulfatide significantly suppressed $\alpha$-GalCer-induced protection (Ambrosino, et al., 2007). Thus, this observation defined a new immunoregulatory axis between type I and type II NKT cells (Ambrosino, et al., 2008; Berzofsky and Terabe, 2008; Terabe and Berzofsky, 2007), analogous to the one between Th1 and Th2 cells (Fig. 3). Because NKT cells are among the earliest immune responders, the balance along the type I-type II NKT axis may determine the nature of the subsequent adaptive immune response, including Th1/Th2 balance. Manipulating the balance along this axis could steer vaccine or immunotherapeutic responses in different directions.

Although the mechanism of this interplay between type I and type II NKT cells remains unclear in tumor settings, it seems to require cell-cell contact. It was reported that in a ConA-induced hepatic injury model, sulfatide-activated type II NKT cells anergize type I NKT cell activation through an anergic plasmacytoid DC that attracts type I NKT cells via MIP-2 and IL-12 (Halder, et al., 2007). Therefore, it is possible that two types of NKT cells may interact through intermediary cells.

\section{B. Interaction of NKT cells with Treg cells}

$\mathrm{CD} 4^{+} \mathrm{CD} 25^{+} \mathrm{T}$ regulatory cells (Treg cells) have been found to suppress multiple functions of other immune cells (Sakaguchi, 2004; Terabe and Berzofsky, 2004). Interaction between NKT cells and Treg cells is not well studied yet. However, there are some reports showing potential two-way interactions between type I NKT cells and Treg cells. In some types of tumors, the number of Tregs in cancer patients is negatively correlated with disease prognosis (Curiel et al., 2004). On the other hand, IFN- $\gamma$ production of type I NKT cells, which has been shown to be a key for NKT cell-initiated tumor immunity in mouse tumor models, has been shown to be suppressed in cancer patients (Fujii, et al., 2003a; Kenna, et al., 2003; Tahir, et al., 2001; van der Vliet, et al., 2003; Yanagisawa, et al., 2002). In colorectal cancer patients, a correlation between the numbers of cancer infiltrating type I NKT cells and prognosis was also reported (Tachibana, et al., 2005). Therefore, it is possible that Treg cell function involves the suppression of NKT cells in the patients. In fact, this seems to be the case in both mice and humans. In a lung metastasis model of methylcholanthrene-induced tumors, adoptive transfer of Treg cells induced by a tumor antigen increased tumor burden (Nishikawa, et al., 2003). 
The Treg cell-transfer significantly reduced the number of type I NKT cells from the lungs of tumor challenged mice, although it did not affect the numbers of other T cell subsets. Although tumor susceptible $\mathrm{J} \alpha 18^{-/-}$mice had reduced tumor burden upon adoptive transfer of type I NKT cells, simultaneous induction of tumor antigen-specific Treg cells abrogated the effect of type I NKT cell-transfer. Thus, tumor antigen-specific Treg cells suppress the protective function of type I NKT cells. Similarly, human Treg cells were shown to suppress the proliferative response and cytokine production of human type I NKT cells in response to $\alpha$ GalCer-pulsed monocyte-derived DCs (Azuma et al., 2003). The suppression was observed against all three, $\mathrm{CD}^{+}, \mathrm{CD}^{+}$and $\mathrm{CD}^{-}{ }^{-} \mathrm{CD} 8^{-}$, subpopulatons of human type I NKT cells. Although the precise mechanism of the suppression is not clear, it is cell-to-cell contact mediated.

Interestingly, in contrast, NKT cells seem to induce or cooperate with Treg cells in an oral tolerance induction model and autoimmune disease models. CD4 ${ }^{+}$type I NKT cells were necessary for induction of oral tolerance to nickel (Roelofs-Haarhuis et al., 2003). In this system $\mathrm{J} \alpha 18^{-/-}$mice did not become tolerant. Adoptive transfer of APC but not T cells from immunized $\mathrm{J} \alpha 18^{-1-}$ mice could transfer tolerance in wild-type mice since there were no induced Treg cells in the T cell fraction of $\mathrm{J} \alpha 18^{-/-}$mice. NK $1.1^{+}$cell-depleted T cells from immunized wild-type mice did transfer the tolerance into $\mathrm{J} \alpha 18^{-1-}$ mice. These results indicated that there is a sequential interaction among APC, type I NKT cells and Treg cells, which is that APC instruct type I NKT cells and then type I NKT cells induce Treg cells. The interaction between APC and type I NKT cells requires CD1d since the APC from CD1d ${ }^{-/}$mice did not transfer the tolerance to naïve recipients. IL-4 and IL-10 were necessary for type I NKT cells to induce Treg cells.

In an experimental autoimmune myasthenia gravis model, activation of type I NKT cells by $\alpha$-GalCer increased the size of the population of Treg cells (La Cava et al., 2006; Liu et al., 2005b). These Treg cells manifested augmented Foxp3 expression, which is critical for their differentiation and function, and greater potency to inhibit the proliferative response of autoreactive T cells. The expansion of Treg cells seems to be due to IL-2 production by the activated type I NKT cells since neutralization of IL-2 abrogated the effect of $\alpha$-GalCer treatment. Type I NKT cell support of Treg expansion seems to happen in humans as well (Jiang et al., 2005).

A similar effect of $\alpha$-GalCer-induced type I NKT cell action on Treg cells to suppress autoimmunity was also reported in NOD mice (Li et al., 2008). It was also reported that the anti-diabetogenic activity of $\alpha$-GalCer treatment requires Treg cells since anti-CD 25 treatment, which abrogates Treg function, abrogated $\alpha$-GalCer-induced protection of mice from type I diabetes (Ly et al., 2006). These observations in autoimmune models suggest that type I NKT cells support and require Treg cells to suppress autoimmunity.

It is unclear why Treg suppress type I NKT cells in tumor settings and type I NKT cells cooperate with Treg cells in autoimmune settings. Further, how type II NKT cells fit in this picture may be another interesting question worthy of study.

\section{Interaction of NKT cells with NK cells}

As described above, activation of NK cells by type I NKT cells is crucial for enhancement of tumor immunity by type I NKT cells with or without the involvement of exogenous $\alpha$-GalCer. Type I NKT cells activated by $\alpha$-GalCer have been shown to rapidly produce IFN- $\gamma$. This IFN$\gamma$ together with IL-12 from antigen presenting cells, presumably DCs, leads to activation of NK cells in vivo (Carnaud, et al., 1999; Eberl and MacDonald, 2000). In addition to these two cytokines, IL-2 from activated NKT cells also supports NK activation, at least in humans (Metelitsa, et al., 2001). Interestingly, this bystander activation and proliferation selectively 
affected NK cells but not B cells or T cells (Eberl and MacDonald, 2000). Sequential production of IFN- $\gamma$ by type I NKT cells and NK cells was also shown to be necessary for NKT cellmediated protection against tumors (Smyth, et al., 2002) and cytomegalovirus infection (van Dommelen et al., 2003). The precise mechanism of activation and proliferation of NK cells elicited by activated type I NKT cells to enhance tumor immunity and effector molecules for tumor lysis may differ between liver and non-hepatic organs in tumor settings (Hayakawa et al., 2001a; Miyagi et al., 2003; Smyth, et al., 2002). In natural tumor immunosurveillance in a methylcholanthrene-induced fibrosarcoma model, in which type I NKT cells induce protection, CD1d-restricted antigen recognition by type I NKT cells activated NK cells as well as $\mathrm{CD}^{+} \mathrm{T}$ cells through IFN- $\gamma$ production (Crowe, et al., 2002). Although both type I NKT cells and NK cells were necessary for the protection (Smyth, et al., 2001), perforin production, one of the mechanisms of cell lysis, was not required for type I NKT cells but only for NK cells (Crowe, et al., 2002), implying that the primary role of NKT cells was indirect, through $\mathrm{NK}$ and $\mathrm{CD} 8^{+} \mathrm{T}$ cells, not through direct lytic activity.

Similar to the observations in mice, $\alpha$-GalCer activation of human type I NKT cells was shown to elicit NK cell-mediated tumor cell lysis (Ishihara, et al., 2000) through IL-2 and IFN- $\gamma$ production by type I NKT cells (Metelitsa, et al., 2001). Importantly, the activation of NK cells was also observed in cancer patients treated with $\alpha$-GalCer-pulsed DCs (Nieda, et al., 2004). The stimulatory activity of type I NKT cells on NK cells was greater in the $\mathrm{CD} 4^{+}$subset compared to the $\mathrm{CD} 8^{+}$or $\mathrm{CD}^{-} \mathrm{CD}^{-}$subsets of NKT cells (Lin et al., 2006).

Conversely, there is evidence for effects of NK cells on NKT cells as well. NK cells but not Kupffer cells were shown to be necessary for thymic CD4 ${ }^{+}$NKT cells to home to the liver through LFA-1 (Miyamoto et al., 2000). NK cells activated by IL-12 and IL-18 were also shown to overcome the immunosuppressive effect of NKT cells to induce protection against tumors (Subleski, et al., 2006). Thus, there is a two-way interaction between NKT cells, especially type I, and NK cells to facilitate immunity against tumors and infections.

\section{Interaction of NKT cells with myeloid derived suppressor cells (MDSC) and M2 macrophages}

MDSC (defined as CD11 $\mathrm{b}^{+} \mathrm{Gr}-1^{+}$cells) are immature myeloid cells with immunosuppressive properties such as production of arginase, inducible nitric oxide, and TGF- $\beta$ (Bronte and Zanovello, 2005; Gabrilovich, 2004). In many mouse tumor models and human cancer patients, accumulation of this myeloid cell lineage cell has been described (Almand et al., 2001; Bronte and Zanovello, 2005; Gabrilovich, 2004; Mirza et al., 2006; Pak et al., 1995; Schmielau and Finn, 2001; Zea et al., 2005). IL-13 from CD4 ${ }^{+}$type II NKT cells induced TGF- $\beta$ production by $\mathrm{CD} 11 \mathrm{~b}^{+} \mathrm{Gr}-1^{+}$cells to suppress tumor-specific $\mathrm{CD} 8^{+} \mathrm{T}$ cells in two mouse tumor models, 15-12RM subcutaneous and CT26 lung metastatic tumors, as described above (Section III.C. 2) (Park, et al., 2004; Terabe, et al., 2003a). In an orthotropic 4T1 breast tumor model, NKT cells were reported to suppress tumor immunity by IL-13 production to induce M2 macrophages and to suppress iNOS-producing M1 macrophages (Sinha, et al., 2005a). Furthermore, NKT cells seem to contribute to an increase in MDSC since $\mathrm{CD} 1^{-1-}$ mice also had reduced MDSC. Therefore, it appears that immunosuppressive NKT cells induce MDSC (or myeloid lineage cells) to suppress tumor immunity.

$\mathrm{CD} 11 \mathrm{~b}^{+} \mathrm{Gr}-1^{+}$cells were also reported to be responsible for type I NKT cell-induced early graft rejection of syngeneic transplanted islets through IFN- $\gamma$ production by $\mathrm{CD} 11 \mathrm{~b}^{+} \mathrm{Gr}-1^{+}$ cells. However, repeated injection of $\alpha$-GalCer to stimulate type I NKT cells dramatically reduced IFN- $\gamma$ production by $\mathrm{CD} 11 \mathrm{~b}^{+} \mathrm{Gr}-1^{+}$cells and prevented the graft rejection (Yasunami et al., 2005). 
$\mathrm{CD} 11 \mathrm{~b}^{+} \mathrm{Gr}-1^{+}$cells can also be responsible for the poor effect of $\alpha$-GalCer in a therapeutic setting in some mouse tumor models. The myeloid cells suppress type I NKT cell-activation by $\alpha$-GalCer through nitric oxide production in the B16 melanoma and 3LL Lewis lung cancer models (Yanagisawa et al., 2006). Interestingly, retinoic acid administration reduced the number of $\mathrm{CD} 11 \mathrm{~b}^{+} \mathrm{Gr}-1^{+}$cells in tumor bearing mice and restored responsiveness of type I NKT cells to $\alpha$-GalCer (Yanagisawa, et al., 2006).

\section{E. Interaction of NKT cells with dendritic cells}

As mentioned above (Section II.E.1.c), the interplay between type I NKT cells and DC has been interpreted to be a key factor in the anti-tumor effect of $\alpha$-GalCer. Activation of type I NKT cells by $\alpha$-GalCer induces maturation of DC by up-regulating co-stimulatory molecules, class II MHC, and IL-12 production (Fujii, et al., 2003b; Ishikawa et al., 2005b). This induction of DC maturation facilitates antigen specific $\mathrm{CD} 4^{+}$and $\mathrm{CD} 8^{+} \mathrm{T}$ cell responses. For antigen specific $\mathrm{CD} 8^{+} \mathrm{T}$ cell induction, type I NKT cells can provide "help" even in class II MHC deficient mice, which lack conventional CD4 ${ }^{+} \mathrm{T}$ cells, when DCs present $\alpha$-GalCer (Stober et al., 2003). Type I NKT cell activation can also locally increase one type of DCs to modulate immune responses. $\alpha$-GalCer has been shown to prevent disease onset of type I diabetes in NOD mice (Wilson and Delovitch, 2003). A suggested mechanism of $\alpha$-GalCer action is the increase of tolerogenic CD8 ${ }^{-}$myeloid DCs in pancreatic draining lymph nodes (Naumov et al., 2001). Also, sulfatide-activated type II NKT cells are reported to recruit plasmacytoid DCs to induce tolerance of type I NKT cells (see Section IV.A above) (Halder, et al., 2007).

Human type I NKT cells are able to instruct monocytes to differentiate into immature DC without $\alpha$-GalCer activation in vitro in a CD1d-dependent manner (Hegde et al., 2007). The instruction is mediated by GM-CSF and IL-13 production by NKT cells activated by recognizing autoantigens presented by CD1d on monocytes. Type I NKT cells (CD4 ${ }^{-} \mathrm{CD} 8^{-}$ population) also can regulate immune responses by specifically killing DCs among CD1d expressing cells when the NKT cells get activated (Nicol et al., 2000). Thus, NKT cells eliminate antigen presenting cells that effectively activate naïve $\mathrm{T}$ cells.

On the other hand, DCs also actively modulate NKT cell function. DCs provide several costimulatory molecules such as B7 (CD80) and CD40. Although some studies suggested that B7-CD 28 costimulation was necessary for both interferon- $\gamma$ and IL-4 production by NKT cells, whereas CD40L-CD40 costimulation was more important for interferon- $\gamma$ (Hayakawa et al., 2001b), a later study that avoided effects of bystander cell cytokine production by studying only CD1d-tetramer-positive cells found that both of these costimulatory interactions were necessary only for NKT cell proliferation, but not for cytokine production (Uldrich et al., 2005). Myeloid DCs in the peripheral blood of melanoma and renal cell cancer patients induce incomplete activation of type I NKT cells with reduced levels of CD25 expression and IFN$\gamma / \mathrm{IL}-4$ ratio (van der Vliet, et al., 2008). This is partly mediated by TGF- $\beta$ and IL-10. This may provide a rationale for observations that type I NKT cells from cancer patients cannot make IFN- $\gamma$ but do make IL-4. However, this dysfunction of type I NKT cells is reversible, as defective type I NKT cells can recover their ability to produce IFN- $\gamma$ by treatment with IL-12 or matured DC presenting $\alpha$-GalCer. Also, activation of the type I NKT cells by $\alpha$-GalCerloaded DC with IL-15 restores IFN- $\gamma$ production (van der Vliet, et al., 2003).

DCs stimulated through TLR9, a receptor for CpG oligodeoxynucleotides, induce selective production of IFN- $\gamma$ by type I NKT cells (Paget et al., 2007). TLR9 ligand-stimulated DCs instruct type I NKT cells by enhanced production of glycosphingolipids and their presentation by CD1d and type I IFN production by the plasmacytoid DCs (pDCs). Similarly, various TLR stimulations have been shown to modulate the lipid biosynthetic pathway to enhance recognition of CD1d-associated lipids by the TCR of type I NKT cells (Salio et al., 2007). In humans, TLR9 is selectively expressed on pDCs that do not express CD1d (Liu, 2005). TLR9- 
activated pDCs partially activate type I NKT cells through cytokine production, with upregulation of activation markers such as CD69 but no cytokine induction (Montoya et al., 2006). This is in part mediated by type I IFN but also by other soluble factors. Then these partially activated type I NKT cells become more responsive to $\alpha$-GalCer presentation by myeloid DCs. Thus, type I NKT cells act as a mediator between pDCs and mDCs. Type I IFN was reported to augment the number of type I NKT cells in multiple sclerosis patients (Gigli et al., 2007). Monocyte-derived DCs from type I IFN-treated patients also showed better capability for $\alpha$-GalCer presentation to induce cytokine production. Hence, type I NKT cells and DCs have a two-way interaction to instruct each other. However, the interaction between type II NKT cells and DCs remains to be studied.

\section{POTENTIAL TRANSLATIONAL APPROACHES}

\section{A. Active therapy approaches}

Although activation of type I NKT cells by giving soluble $\alpha$-GalCer in vivo has been shown to induce very potent anti-tumor immunity in mouse tumor models, so far success in humans has been very much limited. This inefficiency of $\alpha$-GalCer treatment in humans may be partly due to existence of anti-alpha-linked sugar natural antibodies in humans that do not exist in the mouse (Galili et al., 1987; Galili et al., 1988; Yoshimura et al., 2001). Now the field is moving forward to look for more potent ways to use $\alpha$-GalCer to treat cancers. These include delivering $\alpha$-GalCer in non-soluble forms, simultaneous activation of multiple immune cell populations of innate immunity, using $\alpha$-GalCer as an adjuvant to induce tumor specific adaptive immunity, and adoptive transfer of expanded autologous NKT cells (Table III).

1. $\alpha$-GALCER THERAPY - In many studies using $\alpha$-GalCer in mouse tumor models, mice are given a single injection at the time of tumor challenge. In many tumor models, the window of time in which $\alpha$-GalCer can show an impact on tumor growth seems to be narrow. Since it is impossible to treat cancer patients when they start developing tumors, a better regimen for the $\alpha$-GalCer treatment has to be developed. If a single injection of $\alpha$-GalCer does not induce enough activation of type I NKT cells, one may try multiple injections. Multiple injections of $\alpha$-GalCer were shown to have a therapeutic effect against liver metastasis of the B16 melanoma (Kawano et al., 1998). In multiple spontaneous tumor models including carcinogen-induced and oncogene transgenic mouse models, multiple injections of $\alpha$-GalCer delayed and lowered the probability of tumor development (Hayakawa, et al., 2003). More impressively, even with a delay of the start of the treatment for 4 weeks, there was a significant effect on tumor development in methylcholanthrene-induced spontaneous tumors. IFN- $\gamma$ and TRAIL seem to play a critical role in the protection in this setting. However, in contrast, it should be noted that it was reported that in naïve mice, multiple injections of $\alpha$-GalCer polarized the cytokine profile of activated type I NKT cells towards Th2 (Burdin, et al., 1999).

Critical mechanisms of $\alpha$-GalCer to enhance tumor immunity are induction of IFN- $\gamma$ and activation of NK cells. Therefore, combining exogenous cytokines to accelerate IFN- $\gamma$ production and/or NK activation with $\alpha$-GalCer may induce stronger immunity. Several different cytokines have been reported to increase the efficacy of $\alpha$-GalCer to activate tumor immunity. A low dose of IL-12, which is insufficient to activate NK cells by itself (Takeda, et al., 2000a), with $\alpha$-GalCer was shown to increase tumor immunity against the B16F10 melanoma, RM-1 prostate carcinoma (Smyth, et al., 2000a), and B16-BL6-HM melanoma tumors (Nakui, et al., 2000). Administration of IL-21, which induces maturation of NK cells, after $\alpha$-GalCer treatment either by free $\alpha$-GalCer or $\alpha$-GalCer-pulsed DCs, was reported to show better protection against the B16F10 melanoma, the 4T1 mammary carcinoma, a RENCA prostate tumor, and methylcholanthrene-induced spontaneous tumors (Smyth, et al., 2005). IL-21 worked better than either IL-2 or IL-12 in this setting. 
CD40 stimulation plays a critical role in the maturation of DCs and interaction of T cells and B cells with DCs. However, agonistic mAb against CD40 can be toxic to human patients. Teng et al recently demonstrated that in combination with agonistic antibodies against DR5, a cell death-inducing TRAIL receptor, and 4-1BB, a costimulatory molecule on T cells, $\alpha$-GalCer can substitute for the effect of anti-CD40 to induce strong anti-tumor immune reponses (Teng, et al., 2007). This treatment can eradicate well established day $244 \mathrm{~T} 1$ breast tumors in a IFN$\gamma$ dependent fashion. However, liver toxicity was also reported in mice with this combination therapy.

NKT cells show lytic activity when activated through the TCR (Kawano, et al., 1998), and this function does not seem to be suppressed in cancer patients. However, many tumors down regulate the expression of CD1d on their surface. A bifunctional protein, a fusion protein of $\mathrm{CD} 1 \mathrm{~d}$ and anti-tumor antigen $\mathrm{mAb}$, may take an advantage of not only cytokine production capability but also lytic activity of type I NKT cells. A CD1d-anti-Her2-scFv fusion protein was shown to have therapeutic efficacy when loaded with $\alpha$-GalCer in a Her2-transfected B16 melanoma lung metastasis model (Stirnemann et al., 2008). In this model, repeated injection of the fusion protein starting day 2 after tumor injection significantly reduced tumor nodules in contrast to a repeated injection of free $\alpha$-GalCer. The protection was associated with an increased type I NKT cell number, IFN- $\gamma$ production by both type I NKT cells and NK cells and enhanced DC maturation. Not only NKT cells but also NK cells were responsible for the anti-tumor effect. The systemically injected fusion protein accumulated in the Her-2 expressing tumors, and significant expansion of proliferating type I NKT cells, NK cells, and T cells was observed.

Combining $\alpha$-GalCer with other agents that facilitate antigen presentation is another strategy. Recently, lenalidomide, a thalidomide analog, was reported to enhance the proliferative response and IFN- $\gamma$ production of healthy and myeloma patient donors upon $\alpha$-GalCer stimulation (Chang et al., 2008). This effect was further enhanced by dexamethasone.

2. $\alpha-G A L C E R$ PULSED DCs OR TUMOR CELLS-DCs are very potent antigen presenting cells expressing high levels of co-stimulatory molecules. For type I NKT cell activation with $\alpha$-GalCer, interaction of type I NKT cells with DCs is a key factor for the antitumor activity of $\alpha$-GalCer. Thus, one may expect that giving $\alpha$-GalCer pulsed DC may induce a strong anti-tumor effect. In fact, injection of $\alpha$-GalCer-loaded DC has been shown to have a therapeutic effect against liver metastasis of the B16 melanoma (Toura, et al., 1999) and Panc02 pancreatic tumor (Nagaraj et al., 2006). Furthermore, $\alpha$-GalCer pulsed DCs prolonged IFN- $\gamma$ production by type I NKT cells in vivo compared to injection of soluble $\alpha$-GalCer (Fujii, et al., 2002). This treatment also enhanced tumor immunity in lung metastases of the B16 melanoma. Based on these studies, multiple phase I clinical trials of $\alpha$-GalCer pulsed DC were conducted in cancer patients (Ishikawa, et al., 2005a; Okai, et al., 2002; Uchida et al., 2008; van der Vliet, et al., 2003). A significant increase of type I NKT cells in peripheral blood after the treatment was commonly observed among the trials. In some trials increased levels of IL-12 and IP-10 in peripheral blood were associated with $\alpha$-GalCer pulsed DC administration (Chang, et al., 2005). The increase of type I NKT cell number may be a key step to achieving success for $\alpha$ GalCer treatment since reduction of type I NKT cell number is a characteristic of cancer patients (Molling et al., 2005), and may be responsible in part for the poor success of $\alpha$-GalCer clinical trials in patients. It is possible that pulsing DCs or tumor cells with $\alpha$-GalCer will bypass the potential problem of natural antibodies to alpha-linked galactose present in humans but not in mice (Galili, et al., 1987; Galili, et al., 1988; Yoshimura, et al., 2001). However, there are other potential reasons for less apparent success is humans than in mice, such as the fact that clinical trials so far have been carried out on patients with advanced cancer, whereas mice were treated at an earlier stage of disease. 
However, it is cumbersome to induce and expand DC from patients' peripheral blood monocytes to give back to the patients. It may be possible to use B cells to pulse with $\alpha$-GalCer and tumor antigens to induce long lasting tumor-specific immunity (Chung, et al., 2006; Kim, et al., 2008).

It is also worth trying to use CD1d-expressing tumor cells as a vehicle to deliver $\alpha$-GalCer in vivo, as now a couple of studies demonstrated inducing effective tumor immunity in mouse tumor models by this approach (Chung et al., 2007; Shimizu, et al., 2007a), although induced effector arms may differ among different tumor models. However, this approach has the strong rationale that the tumor cells used as a vehicle serve as a source of tumor antigens when the tumor cells die because of irradiation (irradiated tumors are used as a vehicle) or are lysed by $\alpha$-GalCer-activated type I NKT cells and NK cells activated by IFN- $\gamma$ from the NKT cells. Those lysed or apoptotic tumor cells are taken up by DCs to induce tumor antigen-specific $\mathrm{CD}^{+}$and $\mathrm{CD}^{+} \mathrm{T}$ cells (Shimizu, et al., 2007b). These T cells can be responsible for the longlasting tumor antigen-specific adaptive immunity, which is critical to induce appropriate tumor immunity.

3. $\alpha$-GALCER AS A VACCINE ADJUVANT-The mature DC is a very powerful antigen presenting cell to activate naïve T cells. Since activation of type I NKT cells by $\alpha$-GalCer induces massive cytokine production, activation of adaptive arms of immunity (Nishimura et al., 2000) and DC maturation, adjuvant effects of $\alpha$-GalCer have been tested (Fujii, et al., $2003 b)$. Intravenous injection of $\alpha$-GalCer with OVA protein induces OVA specific $\mathrm{CD}^{+}$and $\mathrm{CD} 8^{+}$with strong IFN- $\gamma$ production but not IL-4 production. Interestingly, this adjuvant effect is uniquely on DCs but not on B cells, although marginal zone B cells are known to express a high level of CD1d (Kitamura et al., 2000; Roark et al., 1998; Sonoda and Stein-Streilein, 2002). A similar adjuvant effect can be seen with OCH (Silk, et al., 2004), which has been shown to induce a more Th2 skewed cytokine profile in type I NKT cells (Miyamoto, et al., 2001). Interestingly, the adjuvant effect of $\alpha$-GalCer requires type I NKT cells, CD1d and CD40 but not IFN- $\gamma$. Furthermore, $\alpha-\mathrm{GalCer}$ and specific antigens have to be presented by the same DC (Hermans et al., 2003). T cells activated by these DC can lead to rejection of tumors expressing the antigen used for immunization. Similarly, giving an antigen with $\alpha$-GalCer via the intranasal route induces significant secretory $\operatorname{IgA}$, systemic IgG and a CTL response sufficient to protect mice from influenza virus challenge and a tumor (Ko, et al., 2005; Youn et al., 2007).

This idea was extended by combining $\alpha$-GalCer with TLR ligands. TLR4 ligand monophosphoryl lipid A, TLR 9 ligand $\mathrm{CpG}$, and TLR 5 ligand flagellin were shown to enhance the adjuvant effect of $\alpha$-GalCer to induce antigen specific CTLs (Hermans et al., 2007; Silk, et al., 2004) by inducing further maturation of DCs. Similar effects of the combination of $\alpha$ GalCer and TLR ligands were observed on human DCs.

Moreover, stimulation of various TLRs has been shown to change expression of enzymes involved in the glycosphingolipid synthetic pathway. This change strengthens the TCR mediated stimuli in NKT cells (Paget, et al., 2007; Salio, et al., 2007). Thus, besides induction of DC maturation, using TLR ligands may have a beneficial effect along with $\alpha$-GalCer for tumor immunity.

4. ADOPTIVE TRANSFER THERAPY-If expansion of the number of type I NKT cells is critical for $\alpha$-GalCer therapy of cancers, one may think to expand them ex vivo and transfer the cells back into the patients. In mice, lines of type I NKT cells maintained long-term (up to 2 years) in culture by stimulation with $\alpha$-GalCer pulsed syngeneic DCs, retained their ability to secrete Th1 and Th2 cytokines and to mediate protection against the B16 F10 melanoma when adoptively transferred into naïve syngeneic C57BL/6 mice (Molling, et al., 2008). One 
phase I study was reported with advanced and recurrent lung cancer patients (Motohashi, et al., 2006). Since it is well tolerated, and since myeloid DCs in cancer patients may suppress the activation of type I NKT cells in vivo (van der Vliet, et al., 2008), this may be a potential approach to recover the number of type I NKT cells in cancer patients.

Overall, the approaches discussed above have a potential to enhance the anti-tumor effect of $\alpha$-GalCer and seem to be promising. Translation of these novel approaches is anticipated with high expectation.

\section{B. Blockade of negative regulation}

Stimulating type I NKT cells by $\alpha$-GalCer or its analogs is to "push" the tumor immunity. On the other hand, we have learned that there are multiple negative regulatory mechanisms in tumor-bearing individuals that dampen the tumor immunity, among which, type II NKT cells play a prominent role in some settings. Therefore, another potential translational strategy to improve tumor immunity is to block the negative regulatory mechanisms to "pull" the immune responses (Table III).

1. IL-13 INHIBITION-In some tumor models, IL-13 has been shown to play a key role in the negative regulatory pathway initiated by $\mathrm{CD}^{+}$type II NKT cells (Park, et al., 2004; Terabe, et al., 2000). In these models, blockade of IL-13 or its signaling significantly reduced tumor burden without the involvement of vaccines (Fichtner-Feigl, et al., 2008; Park et al., 2008; Park, et al., 2004; Terabe, et al., 2000). NKT cell-derived IL-13 in tumor-bearing animals was also shown to be a key to induce M2 macrophages, an immunosuppressive macrophage population (Sinha, et al., 2005a). Therefore, blockade of IL-13 is a reasonable approach to improve tumor immunity suppressed by regulatory type II NKT cells or M2 macrophages. The blockade of IL-13 also directly kills tumors that use IL-13 as a growth factor such as Hodgkin's lymphoma (Kapp et al., 1999; Skinnider et al., 2002a; Skinnider et al., 2001; Skinnider et al., 2002b; Trieu et al., 2004). Thus, it can be expected that those tumor cells killed by an IL-13 inhibitor may serve as a vaccine to enhance tumor-specific adaptive immunity when natural immunosurveillance is improved. In fact, it was reported that blockade of IL-13 or abrogation of NKT cells can improve vaccine efficacy to induce anti-viral immunity (Ahlers et al., 2002).

2. TGF- $\beta$ INHIBITION-TGF- $\beta$ is a pleiotropic cytokine with a very potent immunosuppressive activity. This cytokine can suppress T cells, NK cells, DCs, macrophages (Letterio and Roberts, 1998) and maybe NKT cells as well. TGF- $\beta$ has been considered a major target of tumor immunotherapy for long time since tumors make a large amount of TGF- $\beta$ and some studies showed an inverse correlation between the level of TGF- $\beta$ in the peripheral blood of cancer patients and disease prognosis (Teicher, 2007). However, now immune cells have been gradually gaining recognition as an important source of TGF- $\beta$ to regulate tumor immunity (Terabe, et al., 2003a; Yang et al., 2008b). NKT cells were also shown to produce TGF- $\beta$ to suppress anti-tumor immunity (Tamada et al., 1997). IL-13 from type II NKT cells was also shown to induce TGF- $\beta$ production by $\mathrm{CD} 11 \mathrm{~b}^{+} \mathrm{Gr}-1^{+}$myeloid cells in mouse tumor models (Fichtner-Feigl, et al., 2008; Terabe, et al., 2003a). Blockade of TGF- $\beta$ in the tumor models has been shown to reduce tumor burden by improving $\mathrm{CD}^{+} \mathrm{T}$ cell-mediated tumor immunity. As a source of immune-induced TGF- $\beta$, CD $11 b^{+} \mathrm{Gr}-1^{+}$cells may be an important target for cancer treatment (Terabe, et al., 2003a; Yang, et al., 2008b). Furthermore, TGF- $\beta$ has been implicated as a critical development/differentiation factor for two T cell subsets, Treg cells and Th17 cells (Weaver et al., 2006). TGF- $\beta$ may also be important for the maintenance and the functions (Chen et al., 2005) of Treg cells as well. As discussed above, Treg cells suppress T cells that contribute to tumor immunity (Chen, et al., 2005; Golgher et al., 2002; Onizuka et al., 1999; Shimizu et al., 1999; Sutmuller et al., 2001). Th17 is a new subset of 
$\mathrm{CD}^{+} \mathrm{T}$ cells producing IL-17, considered as a major player for many autoimmune diseases (Weaver, et al., 2006). TGF- $\beta$ together with IL- 6 is required for the differentiation of this T cell subset (Bettelli et al., 2006) in mice or IL-21 in humans (Yang et al., 2008a). TGF- $\beta$ also induces $\mathrm{CD} 8^{+} \mathrm{T}$ cells in tumor-bearing mice to secrete IL-17 that promotes tumor cell survival (Nam et al., 2008). Based on this evidence, blockade of TGF- $\beta$ can be a potent approach to improve tumor immunity by affecting multiple immunosuppressive mechanisms. However, it should be noted that mice with fully or partially disrupted TGF- $\beta$ function have phenotypes with severe self-reactive immune responses (Gorelik and Flavell, 2000; Kulkarni et al., 1993; Leveen et al., 2002; Shull et al., 1992). Nevertheless, a couple of clinical trials of TGF$\beta$ antagonists, such as a monoclonal antibody or small molecules that interfere TGF- $\beta$ receptor signaling, in cancer patients are ongoing. Some clinical benefit without apparent induction of autoimmune disease was found in a clinical trial of a human monoclonal anti-TGF- $\beta$ in melanoma patients (Morris et al., 2008).

3. TNF- $\alpha$ INHIBITION-Recently, TNF- $\alpha$ was shown to be involved in the immunosuppressive effect of IL-13 to induce TGF- $\beta$ production by myeloid cells (FichtnerFeigl, et al., 2005). Blockade of TNF- $\alpha$ in vivo improved tumor immunity to reduce tumor burden by reduction of TGF- $\beta$ production by myeloid cells (Fichtner-Feigl, et al., 2008). On the other hand, it is now a widely accepted concept that chronic inflammation, not acute inflammation, contributes to cancer development (Coussens and Werb, 2002; Pardoll, 2002). TNF- $\alpha$ is considered one of the cytokines contributing to chronic inflammation. Given the fact that there are two FDA-approved reagents (infliximab or D2E7 monoclonal antibodies or etanercept soluble receptor) that antagonize TNF- $\alpha$, it would be of interest to test these reagents in cancer patients to improve tumor immunity.

\section{CONCLUSIONS}

For such a small population of cells, NKT cells have an extraordinarily broad and decisive impact on many other components of the immune system and immune responses in health and disease settings, ranging from infectious diseases to autoimmune diseases and cancer. They function as important components of both the innate and the adaptive immune systems, having a foot in both camps and bridging the gap between them. As innate-like cells, they are among the first responders on the scene in many immune responses and therefore set the tone for subsequent adaptive immune responses. As noted in section I.D., it has already been shown that IL-4 from NKT cells can provide the initial cytokine needed to initiate a Th2 response. Conversely, interferon- $\gamma$ from NKT cells can activate other cells like NK cells or CD ${ }^{+} \mathrm{T}$ cells to carry out effector functions, and their ability to induce dendritic cells to secrete IL-12 can initiate Th1 responses. NKT cells function both as regulators and effectors, but perhaps their biggest impact is in regulating other parts of the immune system. In this regard, the newly described immunoregulatory axis between type I and type II NKT T cells can have profound implications. The fact that type I and type II NKT cells can play opposite roles in many diseases, best described so far in cancer and parasitic diseases (see Sections II.D and E, III.B and C, and IV.A), and the new information that they counteract each other (Section IV.A), define a delicately balanced regulatory axis in which the state of the balance is metastable. Just as for the Th1-Th2 axis, whichever gets a head start can dominate and suppress the other. This type of metastable balance can provide stability when needed, but also can allow the immune system to switch on a knife-edge when change is required.

The extent of the role of NKT cells in the adaptive immune system has only recently become appreciated with the discovery of their ability to recognize lipids from a variety of pathogens and contribute to the clearance of these pathogens (See Section II.B.1). Indeed, they fill a critical niche, by providing the immune system with a cellular arm that can recognize lipid antigens, which would otherwise go unnoticed except perhaps by antibodies. As noted in 
Section II.B., this is clearest in the case of certain bacterial pathogens for which the lipids are now defined, but also appears to apply to parasites and viruses as well. They also contribute to protection against infectious diseases as innate responders, through stimulation by IL-12 produced by dendritic cells and macrophages activated by pathogen-derived TLR ligands such as LPS. Their effector role in allergic diseases like asthma may also relate to their ability to detect lipids from allergens like tree pollen, as described in Section II.B.2. Their ability to recognize self lipids may be critical to their role as regulatory cells, for example in suppressing type I diabetes mellitus or in controlling multiple sclerosis-like diseases in animal models.

Thus, the presence or absence of NKT cells has profound effects on many diseases, as witnessed by the substantial differences observed in bacterial, viral, parasitic, autoimmune and malignant diseases in $\mathrm{CD} 1 \mathrm{~d}^{-/-}$mice that lack both types of NKT cells or in $\mathrm{J} \alpha 18^{-/-}$mice that lack only type I NKT cells.

In cancer, as discussed in sections II.E and III.C, we have seen that type I NKT cells are predominantly protective, helping to orchestrate $\mathrm{CD}^{+} \mathrm{T}$ cells and NK cells to inhibit tumor growth through their production of interferon- $\gamma$, and through their activation of dendritic cells to make IL-12 and other cytokines. Conversely, we have seen that type II NKT cells are the primary type of NKT cells responsible for suppression of tumor immunity, through their ability to make IL-13 and induce production of TGF- $\beta$ by myeloid cells. Indeed, it is becoming increasingly recognized that one of the important sources of the TGF- $\beta$ that suppresses tumor immunity may be the immune system itself, not just the tumor, and this may be largely through this mechanism of type II NKT cell induction or other mechanisms that trigger TGF- $\beta$ production by myeloid cells. IL-13 from NKT cells can also recruit M2 tumor-associated macrophages that can suppress tumor immunity. It is also possible that type I NKT cells may suppress immune responses by their ability to stimulate Foxp $3^{+} \mathrm{T}$ regulatory cells, as they have been shown to do in autoimmune diseases (see section IV.B.), and this mechanism needs to be explored in cancer. However, such T reg cells can also suppress type I NKT cell proliferation or function in cancer, and thus $\mathrm{T}$ reg suppression of tumor immunity may be at least in part through suppression of type I NKT cells that promote tumor immunity (see Section IV.B.). It is intriguing that type I NKT cells can play beneficial roles in autoimmune diseases by suppressing immune responses and in infectious diseases and cancer by promoting immune responses, The suppression in autoimmune diseases often involves production of $\mathrm{Th} 2$ cytokines, whereas the beneficial immune responses in infectious diseases and cancer often involve Th1 cytokines. Whether this difference depends on the relative balance of cytokines produced in a given setting or the sensitivity of the particular disease to each type of cytokine remains to be determined. It may also depend on whether autoimmune diseases are dominated by Th1 or Th17 cells, which will be differentially affected by these cytokines, or whether type I NKT cells activate $\mathrm{T}$ reg cells.

If cancer vaccines and immunotherapy are to be successful, it may be critical to overcome the negative regulatory mechanisms that suppress tumor immunity and enhance the mechanisms that promote tumor immunity, and a key part of that process may be to properly set the balance between type I and type II NKT cells along their regulatory axis, as well as the balance between type I NKT cells and T reg cells. Translational approaches may include stimulation of type I NKT cells with agonists such as $\alpha$-GalCer or its analogues or dendritic cells or tumor cells pulsed with these agents, use of these agents as vaccine adjuvants, or adoptive transfer of type I NKT cells expanded ex vivo, or inhibition of negative regulatory mechanisms induced by type II NKT cells, including IL-13, TGF- $\beta$, and myeloid-derived suppressive cells and their products. It may also be necessary to overcome mechanisms that inhibit or suppress type I NKT cells, such as myeloid-derived suppressor cells, T reg cells and immature dendritic cells. The as-yet unknown possibility that type II NKT cells and T reg cells, which both suppress tumor immunity, may interact with each other is intriguing and worthy of future research. Research is also underway to learn what determines which of these suppressive mechanisms 
dominates in any given tumor setting. Likewise, research is ongoing to identify whether there are specific tumor lipid antigens that serve to activate either the protective type I NKT cells or the suppressive type II NKT cells and thus influence both natural immunosurveillance and the potential success of immunotherapy.

Overall, we can conclude that this small population of cells, representing generally less than $1-2 \%$ of human peripheral blood cells or mouse spleen cells, can have such profound effects on the whole immune system because of their ability to regulate other key components of the immune system, dendritic cells, $\mathrm{CD} 8^{+} \mathrm{T}$ cells, $\mathrm{CD}^{+} \mathrm{T}$ cells, NK cells, $\mathrm{T}$ reg cells, myeloid cells such as MDSC, and even other NKT cells. These regulatory roles, combined with their unique ability to recognize lipid antigens of pathogens, tumors, and normal cells, and their rapid response as part of the innate immune system, empower NKT cells to have a profound impact in many disease settings far beyond their strength in numbers. Thus, these relatively newly recognized members of the immune community deserve close attention in developing immunotherapies for cancer, and the ability to manipulate NKT cells may be critical to achieving ultimate success in marshalling the immune system to fight cancer.

\section{Acknowledgments}

Part of the work discussed here was supported by the Intramural Research Program of the NIH, National Cancer Institute, Center for Cancer Research.

\section{References}

Agea E, Russano A, Bistoni O, Mannucci R, Nicoletti I, Corazzi L, Postle AD, De Libero G, Porcelli SA, Spinozzi F. Human CD1-restricted T cell recognition of lipids from pollens. J Exp Med 2005;202:295-308. [PubMed: 16009719]

Ahlers JD, Belyakov IM, Terabe M, Koka R, Donaldson DD, Thomas E, Berzofsky JA. A push-pull approach to maximize vaccine efficacy: abrogating suppression with an IL-13 inhibitor while augmenting help with GM-CSF and CD40L. Proc Natl Acad Sci U S A 2002;99:13020-13025. [PubMed: 12232042]

Akbari O, Faul JL, Hoyte EG, Berry GJ, Wahlstrom J, Kronenberg M, DeKruyff RH, Umetsu DT. CD4 + invariant T-cell-receptor+ natural killer T cells in bronchial asthma. N Engl J Med 2006;354:111729. [PubMed: 16540612]

Akbari O, Stock P, Meyer E, Kronenberg M, Sidobre S, Nakayama T, Taniguchi M, Grusby MJ, DeKruyff RH, Umetsu DT. Essential role of NKT cells producing IL-4 and IL-13 in the development of allergeninduced airway hyperreactivity. Nat Med 2003;9:582-8. [PubMed: 12669034]

Almand B, Clark JI, Nikitina E, van Beynen J, English NR, Knight SC, Carbone DP, Gabrilovich DI. Increased production of immature myeloid cells in cancer patients: a mechanism of immunosuppression in cancer. J Immunol 2001;166:678-89. [PubMed: 11123353]

Ambrosino E, Berzofsky JA, Terabe M. Regulation of tumor immunity: the role of NKT cells. Expert Opin Biol Ther 2008;8:725-34. [PubMed: 18476784]

Ambrosino E, Terabe M, Halder RC, Peng J, Takaku S, Miyake S, Yamamura T, Kumar V, Berzofsky JA. Cross-regulation between type I and type II NKT cells in regulating tumor immunity: A new immunoregulatory axis. J Immunol 2007;179:5126-5136. [PubMed: 17911598]

Amprey JL, Im JS, Turco SJ, Murray HW, Illarionov PA, Besra GS, Porcelli SA, Spath GF. A subset of liver NK T cells is activated during Leishmania donovani infection by CD1d-bound lipophosphoglycan. J Exp Med 2004;200:895-904. [PubMed: 15466622]

Araki M, Kondo T, Gumperz JE, Brenner MB, Miyake S, Yamamura T. Th2 bias of CD4+ NKT cells derived from multiple sclerosis in remission. Int Immunol 2003;15:279-88. [PubMed: 12578858]

Arase H, Arase N, Nakagawa K, Good RA, Onoe K. NK1.1+ CD4+ CD8-thymocytes with specific lymphokine secretion. Eur J Immunol 1993;23:307-10. [PubMed: 8419184] 
Arase H, Arase N, Ogasawara K, Good RA, Onoe K. An NK1.1+ CD4+8-single-positive thymocyte subpopulation that expresses a highly skewed T-cell antigen receptor $\mathrm{V}$ beta family. Proc Natl Acad Sci U S A 1992;89:6506-10. [PubMed: 1378629]

Arase H, Ono S, Arase N, Park SY, Wakizaka K, Watanabe H, Ohno H, Saito T. Developmental arrest of NK1.1+ T cell antigen receptor (TCR)-alpha/beta+ T cells and expansion of NK1.1+ TCR-gamma/ delta+ T cell development in CD3 zeta-deficient mice. J Exp Med 1995;182:891-5. [PubMed: 7650493]

Ashkar AA, Rosenthal KL. Interleukin-15 and natural killer and NKT cells play a critical role in innate protection against genital herpes simplex virus type 2 infection. J Virol 2003;77:10168-71. [PubMed: 12941930]

Assarsson E, Kambayashi T, Sandberg JK, Hong S, Taniguchi M, Van Kaer L, Ljunggren HG, Chambers BJ. CD8+ T cells rapidly acquire NK1.1 and NK cell-associated molecules upon stimulation in vitro and in vivo. J Immunol 2000;165:3673-9. [PubMed: 11034371]

Azuma T, Takahashi T, Kunisato A, Kitamura T, Hirai H. Human CD4+ CD25+ regulatory T cells suppress NKT cell functions. Cancer Res 2003;63:4516-20. [PubMed: 12907625]

Ballas ZK, Rasmussen W. NK1.1+ thymocytes. Adult murine CD4-, CD8-thymocytes contain an NK1.1 +, CD3+, CD5hi, CD44hi, TCR-V beta 8+ subset. J Immunol 1990;145:1039-45. [PubMed: 1696293]

Baron JL, Gardiner L, Nishimura S, Shinkai K, Locksley R, Ganem D. Activation of a nonclassical NKT cell subset in a transgenic mouse model of hepatitis B virus infection. Immunity 2002;16:583-94. [PubMed: 11970881]

Baxter AG, Kinder SJ, Hammond KJ, Scollay R, Godfrey DI. Association between alphabetaTCR+CD4 -CD8- T-cell deficiency and IDDM in NOD/Lt mice. Diabetes 1997;46:572-82. [PubMed: 9075796]

Behar SM, Cardell S. Diverse CD1d-restricted T cells: diverse phenotypes, and diverse functions. Semin Immunol 2000;12:551-60. [PubMed: 11145861]

Behar SM, Dascher CC, Grusby MJ, Wang CR, Brenner MB. Susceptibility of mice deficient in CD1D or TAP1 to infection with Mycobacterium tuberculosis. J Exp Med 1999a;189:1973-80. [PubMed: 10377193]

Behar SM, Podrebarac TA, Roy CJ, Wang CR, Brenner MB. Diverse TCRs recognize murine CD1. J Immunol 1999b;162:161-7. [PubMed: 9886382]

Behar SM, Porcelli SA. CD1-restricted T cells in host defense to infectious diseases. Curr Top Microbiol Immunol 2007;314:215-50. [PubMed: 17593663]

Bendelac A. Positive selection of mouse NK1+ T cells by CD1-expressing cortical thymocytes. J Exp Med 1995;182:2091-6. [PubMed: 7500054]

Bendelac A, Killeen N, Littman DR, Schwartz RH. A subset of CD4+ thymocytes selected by MHC class I molecules. Science 1994a;263:1774-8. [PubMed: 7907820]

Bendelac A, Killeen N, Littman DR, Schwartz RH. A subset of CD4+ thymocytes selected by MHC class I molecules. Science 1994b;263:1774-1778. [PubMed: 7907820]

Bendelac A, Lantz O, Quimby ME, Yewdell JW, Bennink JR, Brutkiewicz RR. CD1 recognition by mouse NK1+ T lymphocytes. Science 1995;268:863-5. [PubMed: 7538697]

Bendelac A, Rivera MN, Park SH, Roark JH. Mouse CD1-specific NK1 T cells: development, specificity, and function. Annu Rev Immunol 1997;15:535-62. [PubMed: 9143699]

Bendelac A, Savage PB, Teyton L. The biology of NKT cells. Annu Rev Immunol 2007;25:297-336. [PubMed: 17150027]

Benlagha K, Weiss A, Beavis A, Teyton L, Bendelac A. In vivo identification of glycolipid antigenspecific T cells using fluorescent CD1d tetramers. J Exp Med 2000;191:1895-903. [PubMed: 10839805]

Berzofsky JA, Terabe M. NKT cells in tumor immunity: opposing subsets define a new immunoregulatory axis. J Immunol 2008;180:3627-35. [PubMed: 18322166]

Bettelli E, Carrier Y, Gao W, Korn T, Strom TB, Oukka M, Weiner HL, Kuchroo VK. Reciprocal developmental pathways for the generation of pathogenic effector TH17 and regulatory T cells. Nature 2006;441:235-8. [PubMed: 16648838] 
Bezbradica JS, Hill T, Stanic AK, Van Kaer L, Joyce S. Commitment toward the natural T (iNKT) cell lineage occurs at the CD4+8+ stage of thymic ontogeny. Proc Natl Acad Sci U S A 2005;102:51149. [PubMed: 15792999]

Bilenki L, Wang S, Yang J, Fan Y, Joyee AG, Yang X. NK T cell activation promotes Chlamydia trachomatis infection in vivo. J Immunol 2005;175:3197-206. [PubMed: 16116210]

Brigl M, Bry L, Kent SC, Gumperz JE, Brenner MB. Mechanism of CD1d-restricted natural killer T cell activation during microbial infection. Nat Immunol 2003;4:1230-7. [PubMed: 14578883]

Bronte V, Zanovello P. Regulation of immune responses by L-arginine metabolism. Nat Rev Immunol 2005;5:641-54. [PubMed: 16056256]

Brossay L, Tangri S, Bix M, Cardell S, Locksley R, Kronenberg M. Mouse CD1-autoreactive T cells have diverse patterns of reactivity to CD1+ targets. J Immunol 1998;160:3681-8. [PubMed: 9558068]

Brozovic S, Nagaishi T, Yoshida M, Betz S, Salas A, Chen D, Kaser A, Glickman J, Kuo T, Little A, Morrison J, Corazza N, Kim JY, Colgan SP, Young SG, Exley M, Blumberg RS. CD1d function is regulated by microsomal triglyceride transfer protein. Nat Med 2004;10:535-9. [PubMed: 15107843]

Brutkiewicz RR. CD1d ligands: the good, the bad, and the ugly. J Immunol 2006;177:769-75. [PubMed: 16818729]

Budd RC, Miescher GC, Howe RC, Lees RK, Bron C, MacDonald HR. Developmentally regulated expression of $\mathrm{T}$ cell receptor beta chain variable domains in immature thymocytes. J Exp Med 1987;166:577-82. [PubMed: 3496420]

Burdin N, Brossay L, Kronenberg M. Immunization with alpha-galactosylceramide polarizes CD1reactive NK T cells towards Th2 cytokine synthesis. Eur J Immunol 1999;29:2014-25. [PubMed: 10382765]

Cardell S, Tangri S, Chan S, Kronenberg M, Benoist C, Mathis D. CD1-restricted CD4+ T cells in major histocompatibility complex class II-deficient mice. J Exp Med 1995;182:993-1004. [PubMed: 7561702]

Carding SR, Egan PJ. Gammadelta T cells: functional plasticity and heterogeneity. Nat Rev Immunol 2002;2:336-45. [PubMed: 12033739]

Carnaud C, Lee D, Donnars O, Park SH, Beavis A, Koezuka Y, Bendelac A. Cutting edge: Cross-talk between cells of the innate immune system: NKT cells rapidly activate NK cells. J Immunol 1999;163:4647-50. [PubMed: 10528160]

Chang DH, Deng H, Matthews P, Krasovsky J, Ragupathi G, Spisek R, Mazumder A, Vesole DH, Jagannath S, Dhodapkar MV. Inflammation associated lysophospholipids as ligands for CD1d restricted T cells in human cancer. Blood 2008;112:1308-1316. [PubMed: 18535199]

Chang DH, Osman K, Connolly J, Kukreja A, Krasovsky J, Pack M, Hutchinson A, Geller M, Liu N, Annable R, Shay J, Kirchhoff K, Nishi N, Ando Y, Hayashi K, Hassoun H, Steinman RM, Dhodapkar MV. Sustained expansion of NKT cells and antigen-specific T cells after injection of $\{$ alpha $\}$ galactosyl-ceramide loaded mature dendritic cells in cancer patients. J Exp Med 2005;201:1503-17. [PubMed: 15867097]

Chen ML, Pittet MJ, Gorelik L, Flavell RA, Weissleder R, von Boehmer H, Khazaie K. Regulatory T cells suppress tumor-specific CD8 T cell cytotoxicity through TGF- $\{$ beta $\}$ signals in vivo. Proc Natl Acad Sci U S A 2005;102:419-24. [PubMed: 15623559]

Chiba A, Oki S, Miyamoto K, Hashimoto H, Yamamura T, Miyake S. Suppression of collagen-induced arthritis by natural killer T cell activation with $\mathrm{OCH}$, a sphingosine-truncated analog of alphagalactosylceramide. Arthritis Rheum 2004;50:305-13. [PubMed: 14730629]

Chiu YH, Jayawardena J, Weiss A, Lee D, Park SH, Dautry-Varsat A, Bendelac A. Distinct subsets of CD1d-restricted T cells recognize self-antigens loaded in different cellular compartments. J Exp Med 1999;189:103-10. [PubMed: 9874567]

Chiu YH, Park SH, Benlagha K, Forestier C, Jayawardena-Wolf J, Savage PB, Teyton L, Bendelac A. Multiple defects in antigen presentation and $\mathrm{T}$ cell development by mice expressing cytoplasmic tailtruncated CD1d. Nat Immunol 2002;3:55-60. [PubMed: 11731798]

Chung B, Aoukaty A, Dutz J, Terhorst C, Tan R. Signaling lymphocytic activation molecule-associated protein controls NKT cell functions. J Immunol 2005;174:3153-7. [PubMed: 15749842] 
Chung Y, Chang WS, Kim S, Kang CY. NKT cell ligand alpha-galactosylceramide blocks the induction of oral tolerance by triggering dendritic cell maturation. Eur J Immunol 2004;34:2471-9. [PubMed: 15307179]

Chung Y, Kim BS, Kim YJ, Ko HJ, Ko SY, Kim DH, Kang CY. CD1d-restricted T cells license B cells to generate long-lasting cytotoxic antitumor immunity in vivo. Cancer Res 2006;66:6843-50. [PubMed: 16818662]

Chung Y, Qin H, Kang CY, Kim S, Kwak LW, Dong C. An NKT-mediated autologous vaccine generates CD4 T-cell dependent potent antilymphoma immunity. Blood 2007;110:2013-9. [PubMed: 17581919]

Coquet JM, Kyparissoudis K, Pellicci DG, Besra G, Berzins SP, Smyth MJ, Godfrey DI. IL-21 is produced by NKT cells and modulates NKT cell activation and cytokine production. J Immunol 2007;178:2827-34. [PubMed: 17312126]

Cornish AL, Keating R, Kyparissoudis K, Smyth MJ, Carbone FR, Godfrey DI. NKT cells are not critical for HSV-1 disease resolution. Immunol Cell Biol 2006;84:13-9. [PubMed: 16277640]

Coussens LM, Werb Z. Inflammation and cancer. Nature 2002;420:860-7. [PubMed: 12490959]

Crough T, Purdie DM, Okai M, Maksoud A, Nieda M, Nicol AJ. Modulation of human Valpha24(+) Vbeta11(+) NKT cells by age, malignancy and conventional anticancer therapies. Br J Cancer 2004;91:1880-6. [PubMed: 15520823]

Crowe NY, Coquet JM, Berzins SP, Kyparissoudis K, Keating R, Pellicci DG, Hayakawa Y, Godfrey DI, Smyth MJ. Differential antitumor immunity mediated by NKT cell subsets in vivo. J Exp Med 2005;202:1279-88. [PubMed: 16275765]

Crowe NY, Smyth MJ, Godfrey DI. A critical role for natural killer T cells in immunosurveillance of methylcholanthrene-induced sarcomas. J Exp Med 2002;196:119-27. [PubMed: 12093876]

Crul M, Mathot RA, Giaccone G, Punt CA, Rosing H, Hillebrand MX, Ando Y, Nishi N, Tanaka H, Schellens JM, Beijnen JH. Population pharmacokinetics of the novel anticancer agent KRN7000. Cancer Chemother Pharmacol 2002;49:287-93. [PubMed: 11914907]

Cui J, Shin T, Kawano T, Sato H, Kondo E, Toura I, Kaneko Y, Koseki H, Kanno M, Taniguchi M. Requirement for Valpha14 NKT cells in IL-12-mediated rejection of tumors. Science 1997;278:1623-6. [PubMed: 9374462]

Curiel TJ, Coukos G, Zou L, Alvarez X, Cheng P, Mottram P, Evdemon-Hogan M, Conejo-Garcia JR, Zhang L, Burow M, Zhu Y, Wei S, Kryczek I, Daniel B, Gordon A, Myers L, Lackner A, Disis ML, Knutson KL, Chen L, Zou W. Specific recruitment of regulatory T cells in ovarian carcinoma fosters immune privilege and predicts reduced survival. Nat Med 2004;10:942-9. [PubMed: 15322536]

Dellabona P, Padovan E, Casorati G, Brockhaus M, Lanzavecchia A. An invariant V alpha 24-J alpha $\mathrm{Q} / \mathrm{V}$ beta $11 \mathrm{~T}$ cell receptor is expressed in all individuals by clonally expanded CD4-8- T cells. J Exp Med 1994;180:1171-6. [PubMed: 8064234]

Dhodapkar KM, Cirignano B, Chamian F, Zagzag D, Miller DC, Finlay JL, Steinman RM. Invariant natural killer T cells are preserved in patients with glioma and exhibit antitumor lytic activity following dendritic cell-mediated expansion. Int J Cancer 2004;109:893-9. [PubMed: 15027123]

Dhodapkar MV, Geller MD, Chang DH, Shimizu K, Fujii S, Dhodapkar KM, Krasovsky J. A reversible defect in natural killer $\mathrm{T}$ cell function characterizes the progression of premalignant to malignant multiple myeloma. J Exp Med 2003;197:1667-76. [PubMed: 12796469]

Diao H, Kon S, Iwabuchi K, Kimura C, Morimoto J, Ito D, Segawa T, Maeda M, Hamuro J, Nakayama T, Taniguchi M, Yagita H, Van Kaer L, Onoe K, Denhardt D, Rittling S, Uede T. Osteopontin as a mediator of NKT cell function in T cell-mediated liver diseases. Immunity 2004;21:539-50. [PubMed: 15485631]

Dieckmann R, Graeber I, Kaesler I, Szewzyk U, von Dohren H. Rapid screening and dereplication of bacterial isolates from marine sponges of the sula ridge by intact-cell-MALDI-TOF mass spectrometry (ICM-MS). Appl Microbiol Biotechnol 2005;67:539-48. [PubMed: 15614563]

Dieli F, Sireci G, Russo D, Taniguchi M, Ivanyi J, Fernandez C, Troye-Blomberg M, De Leo G, Salerno A. Resistance of natural killer T cell-deficient mice to systemic Shwartzman reaction. J Exp Med 2000;192:1645-52. [PubMed: 11104806] 
Dougan SK, Salas A, Rava P, Agyemang A, Kaser A, Morrison J, Khurana A, Kronenberg M, Johnson C, Exley M, Hussain MM, Blumberg RS. Microsomal triglyceride transfer protein lipidation and control of CD1d on antigen-presenting cells. J Exp Med 2005;202:529-39. [PubMed: 16087713]

Duarte N, Stenstrom M, Campino S, Bergman ML, Lundholm M, Holmberg D, Cardell SL. Prevention of diabetes in nonobese diabetic mice mediated by CD1d-restricted nonclassical NKT cells. J Immunol 2004;173:3112-8. [PubMed: 15322171]

Duthie MS, Kahn M, White M, Kapur RP, Kahn SJ. Critical proinflammatory and anti-inflammatory functions of different subsets of CD1d-restricted natural killer T cells during Trypanosoma cruzi infection. Infect Immun 2005;73:181-92. [PubMed: 15618153]

Eberl G, Lowin-Kropf B, MacDonald HR. Cutting edge: NKT cell development is selectively impaired in Fyn- deficient mice. J Immunol 1999;163:4091-4. [PubMed: 10510341]

Eberl G, MacDonald HR. Selective induction of NK cell proliferation and cytotoxicity by activated NKT cells. Eur J Immunol 2000;30:985-92. [PubMed: 10760785]

Egawa T, Eberl G, Taniuchi I, Benlagha K, Geissmann F, Hennighausen L, Bendelac A, Littman DR. Genetic evidence supporting selection of the Valpha14i NKT cell lineage from double-positive thymocyte precursors. Immunity 2005;22:705-16. [PubMed: 15963785]

Elewaut D, Shaikh RB, Hammond KJ, De Winter H, Leishman AJ, Sidobre S, Turovskaya O, Prigozy TI, Ma L, Banks TA, Lo D, Ware CF, Cheroutre H, Kronenberg M. NIK-dependent RelB activation defines a unique signaling pathway for the development of V alpha 14i NKT cells. J Exp Med 2003;197:1623-33. [PubMed: 12810685]

Exley MA, He Q, Cheng O, Wang RJ, Cheney CP, Balk SP, Koziel MJ. Cutting edge: Compartmentalization of Th1-like noninvariant CD1d-reactive $\mathrm{T}$ cells in hepatitis $\mathrm{C}$ virus-infected liver. J Immunol 2002;168:1519-23. [PubMed: 11823474]

Exley MA, Tahir SM, Cheng O, Shaulov A, Joyce R, Avigan D, Sackstein R, Balk SP. A major fraction of human bone marrow lymphocytes are Th2-like CD1d-reactive T cells that can suppress mixed lymphocyte responses. J Immunol 2001;167:5531-4. [PubMed: 11698421]

Faunce DE, Sonoda KH, Stein-Streilein J. MIP-2 recruits NKT cells to the spleen during tolerance induction. J Immunol 2001;166:313-21. [PubMed: 11123307]

Faveeuw C, Angeli V, Fontaine J, Maliszewski C, Capron A, Van Kaer L, Moser M, Capron M, Trottein F. Antigen presentation by CD1d contributes to the amplification of Th2 responses to Schistosoma mansoni glycoconjugates in mice. J Immunol 2002;169:906-12. [PubMed: 12097395]

Fichtner-Feigl S, Strober W, Kawakami K, Puri RK, Kitani A. IL-13 signaling through the IL-13alpha (2) receptor is involved in induction of TGF-beta(1) production and fibrosis. Nat Med 2005;12:99_ 106. [PubMed: 16327802]

Fichtner-Feigl S, Terabe M, Kitani A, Young CA, Fuss I, Geissler EK, Schlitt HJ, Berzofsky JA, Strober W. Restoration of tumor immunosurveillance via targeting of interleukin-13 receptor-alpha 2. Cancer Res 2008;68:3467-75. [PubMed: 18451175]

Fischer K, Scotet E, Niemeyer M, Koebernick H, Zerrahn J, Maillet S, Hurwitz R, Kursar M, Bonneville M, Kaufmann SH, Schaible UE. Mycobacterial phosphatidylinositol mannoside is a natural antigen for CD1d-restricted T cells. Proc Natl Acad Sci U S A 2004;101:10685-90. [PubMed: 15243159]

Forestier C, Molano A, Im JS, Dutronc Y, Diamond B, Davidson A, Illarionov PA, Besra GS, Porcelli SA. Expansion and hyperactivity of CD1d-restricted NKT cells during the progression of systemic lupus erythematosus in (New Zealand Black $\times$ New Zealand White)F1 mice. J Immunol 2005;175:763-70. [PubMed: 16002672]

Forestier C, Takaki T, Molano A, Im JS, Baine I, Jerud ES, Illarionov P, Ndonye R, Howell AR, Santamaria P, Besra GS, Dilorenzo TP, Porcelli SA. Improved outcomes in NOD mice treated with a novel Th2 cytokine-biasing NKT cell activator. J Immunol 2007;178:1415-25. [PubMed: 17237389]

Fowlkes BJ, Kruisbeek AM, Ton-That H, Weston MA, Coligan JE, Schwartz RH, Pardoll DM. A novel population of T-cell receptor alpha beta-bearing thymocytes which predominantly expresses a single V beta gene family. Nature 1987;329:251-4. [PubMed: 3114646]

Fujii S, Shimizu K, Klimek V, Geller MD, Nimer SD, Dhodapkar MV. Severe and selective deficiency of interferon-gamma-producing invariant natural killer T cells in patients with myelodysplastic syndromes. Br J Haematol 2003a;122:617-22. [PubMed: 12899717] 
Fujii S, Shimizu K, Kronenberg M, Steinman RM. Prolonged IFN-gamma-producing NKT response induced with alpha-galactosylceramide-loaded DCs. Nat Immunol 2002;3:867-74. [PubMed: 12154358]

Fujii S, Shimizu K, Smith C, Bonifaz L, Steinman RM. Activation of natural killer T cells by alphagalactosylceramide rapidly induces the full maturation of dendritic cells in vivo and thereby acts as an adjuvant for combined CD4 and CD8 T cell immunity to a coadministered protein. J Exp Med 2003b;198:267-79. [PubMed: 12874260]

Furlan R, Bergami A, Cantarella D, Brambilla E, Taniguchi M, Dellabona P, Casorati G, Martino G. Activation of invariant NKT cells by alphaGalCer administration protects mice from MOG35-55induced EAE: critical roles for administration route and IFN-gamma. Eur J Immunol 2003;33:18308. [PubMed: 12811843]

Fuss IJ, Heller F, Boirivant M, Leon F, Yoshida M, Fichtner-Feigl S, Yang Z, Exley M, Kitani A, Blumberg RS, Mannon P, Strober W. Nonclassical CD1d-restricted NK T cells that produce IL-13 characterize an atypical Th2 response in ulcerative colitis. J Clin Invest 2004;113:1490-7. [PubMed: 15146247]

Gabrilovich D. Mechanisms and functional significance of tumour-induced dendritic-cell defects. Nat Rev Immunol 2004;4:941-52. [PubMed: 15573129]

Gadola SD, Dulphy N, Salio M, Cerundolo V. Valpha24-JalphaQ-independent, CD1d-restricted recognition of alpha-galactosylceramide by human CD4(+) and CD8alphabeta(+) T lymphocytes. J Immunol 2002;168:5514-20. [PubMed: 12023346]

Gadue P, Morton N, Stein PL. The Src family tyrosine kinase Fyn regulates natural killer T cell development. J Exp Med 1999;190:1189-96. [PubMed: 10523617]

Gadue P, Yin L, Jain S, Stein PL. Restoration of NK T cell development in fyn-mutant mice by a TCR reveals a requirement for Fyn during early NK T cell ontogeny. J Immunol 2004;172:6093-100. [PubMed: 15128794]

Galili U, Clark MR, Shohet SB, Buehler J, Macher BA. Evolutionary relationship between the natural anti-Gal antibody and the Gal alpha 1----3Gal epitope in primates. Proc Natl Acad Sci U S A 1987;84:1369-73. [PubMed: 2434954]

Galili U, Shohet SB, Kobrin E, Stults CL, Macher BA. Man, apes, and Old World monkeys differ from other mammals in the expression of alpha-galactosyl epitopes on nucleated cells. J Biol Chem 1988;263:17755-62. [PubMed: 2460463]

Giabbai B, Sidobre S, Crispin MD, Sanchez-Ruiz Y, Bachi A, Kronenberg M, Wilson IA, Degano M. Crystal structure of mouse CD1d bound to the self ligand phosphatidylcholine: a molecular basis for NKT cell activation. J Immunol 2005;175:977-84. [PubMed: 16002697]

Giaccone G, Punt CJ, Ando Y, Ruijter R, Nishi N, Peters M, von Blomberg BM, Scheper RJ, van der Vliet HJ, van den Eertwegh AJ, Roelvink M, Beijnen J, Zwierzina H, Pinedo HM. A phase I study of the natural killer T-cell ligand alpha-galactosylceramide (KRN7000) in patients with solid tumors. Clin Cancer Res 2002;8:3702-9. [PubMed: 12473579]

Gigli G, Caielli S, Cutuli D, Falcone M. Innate immunity modulates autoimmunity: type 1 interferonbeta treatment in multiple sclerosis promotes growth and function of regulatory invariant natural killer T cells through dendritic cell maturation. Immunology 2007;122:409-17. [PubMed: 17617156]

Godfrey DI, Berzins SP. Control points in NKT-cell development. Nat Rev Immunol 2007;7:505-18. [PubMed: 17589542]

Godfrey DI, Kinder SJ, Silvera P, Baxter AG. Flow cytometric study of T cell development in NOD mice reveals a deficiency in alphabetaTCR+CDR-CD8-thymocytes. J Autoimmun 1997;10:279-85. [PubMed: 9218755]

Godfrey DI, MacDonald HR, Kronenberg M, Smyth MJ, Van Kaer L. NKT cells: what's in a name? Nat Rev Immunol 2004;4:231-7. [PubMed: 15039760]

Golgher D, Jones E, Powrie F, Elliott T, Gallimore A. Depletion of CD25+ regulatory cells uncovers immune responses to shared murine tumor rejection antigens. Eur J Immunol 2002;32:3267-75. [PubMed: 12555672]

Gombert JM, Herbelin A, Tancrede-Bohin E, Dy M, Carnaud C, Bach JF. Early quantitative and functional deficiency of NK1+-like thymocytes in the NOD mouse. Eur J Immunol 1996;26:298998. [PubMed: 8977295] 
Gorelik L, Flavell RA. Abrogation of TGFbeta signaling in T cells leads to spontaneous T cell differentiation and autoimmune disease. Immunity 2000;12:171-81. [PubMed: 10714683]

Grubor-Bauk B, Simmons A, Mayrhofer G, Speck PG. Impaired clearance of herpes simplex virus type 1 from mice lacking CD1d or NKT cells expressing the semivariant V alpha 14-J alpha 281 TCR. J Immunol 2003;170:1430-4. [PubMed: 12538704]

Gumperz JE, Miyake S, Yamamura T, Brenner MB. Functionally distinct subsets of CD1d-restricted natural killer T cells revealed by CD1d tetramer staining. J Exp Med 2002;195:625-36. [PubMed: 11877485]

Gumperz JE, Roy C, Makowska A, Lum D, Sugita M, Podrebarac T, Koezuka Y, Porcelli SA, Cardell S, Brenner MB, Behar SM. Murine CD1d-restricted T cell recognition of cellular lipids. Immunity 2000;12:211-21. [PubMed: 10714687]

Halder RC, Aguilera C, Maricic I, Kumar V. Type II NK T cell-mediated anergy induction in type I NK T cells prevents inflammatory liver disease. J Clin Invest 2007;117:2302-2312. [PubMed: 17641782]

Hammond KJL, Poulton LD, Palmisano LJ, Silveira PA, Godfrey DI, Baxter AG. alpha/beta-T cell receptor (TCR)+CD4-CD8- (NKT) thymocytes prevent insulin-dependent diabetes mellitus in nonobese diabetic (NOD)/Lt mice by the influence of interleukin (IL)-4 and/or IL-10. J Exp Med 1998;187:1047-56. [PubMed: 9529321]

Haraguchi K, Takahashi T, Matsumoto A, Asai T, Kanda Y, Kurokawa M, Ogawa S, Oda H, Taniguchi M, Hirai H, Chiba S. Host-residual invariant NK T cells attenuate graft-versus-host immunity. J Immunol 2005;175:1320-8. [PubMed: 16002737]

Hayakawa K, Lin BT, Hardy RR. Murine thymic CD4+ T cell subsets: a subset (Thy0) that secretes diverse cytokines and overexpresses the $\mathrm{V}$ beta $8 \mathrm{~T}$ cell receptor gene family. J Exp Med 1992;176:269-74. [PubMed: 1351921]

Hayakawa Y, Rovero S, Forni G, Smyth MJ. Alpha-galactosylceramide (KRN7000) suppression of chemical- and oncogene-dependent carcinogenesis. Proc Natl Acad Sci U S A 2003;100:9464-9. [PubMed: 12867593]

Hayakawa Y, Takeda K, Yagita H, Kakuta S, Iwakura Y, Van Kaer L, Saiki I, Okumura K. Critical contribution of IFN-gamma and NK cells, but not perforin-mediated cytotoxicity, to anti-metastatic effect of alpha-galactosylceramide. Eur J Immunol 2001a;31:1720-7. [PubMed: 11385616]

Hayakawa Y, Takeda K, Yagita H, Smyth MJ, Van Kaer L, Okumura K, Saiki I. IFN-gamma-mediated inhibition of tumor angiogenesis by natural killer T-cell ligand, alpha-galactosylceramide. Blood 2002;100:1728-33. [PubMed: 12176894]

Hayakawa Y, Takeda K, Yagita H, Van Kaer L, Saiki I, Okumura K. Differential regulation of Th1 and Th2 functions of NKT cells by CD28 and CD40 costimulatory pathways. J Immunol 2001b; 166:6012-8. [PubMed: 11342617]

Hegde S, Chen X, Keaton JM, Reddington F, Besra GS, Gumperz JE. NKT cells direct monocytes into a DC differentiation pathway. J Leukoc Biol 2007;81:1224-35. [PubMed: 17311932]

Hermans IF, Silk JD, Gileadi U, Masri SH, Shepherd D, Farrand KJ, Salio M, Cerundolo V. Dendritic cell function can be modulated through cooperative actions of TLR ligands and invariant NKT cells. J Immunol 2007;178:2721-9. [PubMed: 17312114]

Hermans IF, Silk JD, Gileadi U, Salio M, Mathew B, Ritter G, Schmidt R, Harris AL, Old L, Cerundolo $\mathrm{V}$. NKT cells enhance CD4+ and CD8+ T cell responses to soluble antigen in vivo through direct interaction with dendritic cells. J Immunol 2003;171:5140-7. [PubMed: 14607913]

Imai K, Kanno M, Kimoto H, Shigemoto K, Yamamoto S, Taniguchi M. Sequence and expression of transcripts of the T-cell antigen receptor alpha-chain gene in a functional, antigen-specific suppressor-T-cell hybridoma. Proc Natl Acad Sci U S A 1986;83:8708-12. [PubMed: 2946043]

Ishihara S, Nieda M, Kitayama J, Osada T, Yabe T, Kikuchi A, Koezuka Y, Porcelli SA, Tadokoro K, Nagawa H, Juji T. Alpha-glycosylceramides enhance the antitumor cytotoxicity of hepatic lymphocytes obtained from cancer patients by activating CD3-CD56+ NK cells in vitro. J Immunol 2000;165:1659-64. [PubMed: 10903777]

Ishikawa A, Motohashi S, Ishikawa E, Fuchida H, Higashino K, Otsuji M, Iizasa T, Nakayama T, Taniguchi M, Fujisawa T. A phase I study of alpha-galactosylceramide (KRN7000)-pulsed 
dendritic cells in patients with advanced and recurrent non-small cell lung cancer. Clin Cancer Res 2005a;11:1910-7. [PubMed: 15756017]

Ishikawa E, Motohashi S, Ishikawa A, Ito T, Uchida T, Kaneko T, Tanaka Y, Horiguchi S, Okamoto Y, Fujisawa T, Tsuboi K, Taniguchi M, Matsumura A, Nakayama T. Dendritic cell maturation by CD11c- T cells and Valpha24+ natural killer T-cell activation by alpha-galactosylceramide. Int J Cancer 2005b;117:265-73. [PubMed: 15900581]

Jahng A, Maricic I, Aguilera C, Cardell S, Halder RC, Kumar V. Prevention of Autoimmunity by Targeting a Distinct, Noninvariant CD1d-reactive T Cell Population Reactive to Sulfatide. J Exp Med 2004;199:947-57. [PubMed: 15051763]

Jiang S, Game DS, Davies D, Lombardi G, Lechler RI. Activated CD1d-restricted natural killer T cells secrete IL-2: innate help for CD4+CD25+ regulatory T cells? Eur J Immunol 2005;35:1193-200. [PubMed: 15770696]

Joyce S, Woods AS, Yewdell JW, Bennink JR, De Silva AD, Boesteanu A, Balk SP, Cotter RJ, Brutkiewicz RR. Natural ligand of mouse CD1d1: cellular glycosylphosphatidylinositol. Science 1998;279:1541-4. [PubMed: 9488653]

Kacha AK, Fallarino F, Markiewicz MA, Gajewski TF. Spontaneous Rejection of Poorly Immunogenic P1. HTR Tumors by Stat6- Deficient Mice. J Immunol 2000;165:6024-6028. [PubMed: 11086033]

Kaneko Y, Harada M, Kawano T, Yamashita M, Shibata Y, Gejyo F, Nakayama T, Taniguchi M. Augmentation of Valpha14 NKT cell-mediated cytotoxicity by interleukin 4 in an autocrine mechanism resulting in the development of concanavalin A-induced hepatitis. J Exp Med 2000;191:105-14. [PubMed: 10620609]

Kang SJ, Cresswell P. Saposins facilitate CD1d-restricted presentation of an exogenous lipid antigen to T cells. Nat Immunol 2004;5:175-81. [PubMed: 14716312]

Kapp U, Yeh WC, Patterson B, Elia AJ, Kagi D, Ho A, Hessel A, Tipsword M, Williams A, Mirtsos C, Itie A, Moyle M, Mak TW. Interleukin 13 is secreted by and stimulates the growth of Hodgkin and Reed-Sternberg cells. J Exp Med 1999;189:1939-46. [PubMed: 10377189]

Karadimitris A, Gadola S, Altamirano M, Brown D, Woolfson A, Klenerman P, Chen JL, Koezuka Y, Roberts IA, Price DA, Dusheiko G, Milstein C, Fersht A, Luzzatto L, Cerundolo V. Human CD1dglycolipid tetramers generated by in vitro oxidative refolding chromatography. Proc Natl Acad Sci U S A 2001;98:3294-8. [PubMed: 11248072]

Kawano T, Cui J, Koezuka Y, Toura I, Kaneko Y, Motoki K, Ueno H, Nakagawa R, Sato H, Kondo E, Koseki H, Taniguchi M. CD1d-restricted and TCR-mediated activation of valpha14 NKT cells by glycosylceramides. Science 1997;278:1626-9. [PubMed: 9374463]

Kawano T, Cui J, Koezuka Y, Toura I, Kaneko Y, Sato H, Kondo E, Harada M, Koseki H, Nakayama T, Tanaka Y, Taniguchi M. Natural killer-like nonspecific tumor cell lysis mediated by specific ligand-activated Valpha14 NKT cells. Proc Natl Acad Sci U S A 1998;95:5690-3. [PubMed: 9576945]

Kenna T, Mason LG, Porcelli SA, Koezuka Y, Hegarty JE, O’Farrelly C, Doherty DG. NKT cells from normal and tumor-bearing human livers are phenotypically and functionally distinct from murine NKT cells. J Immunol 2003;171:1775-9. [PubMed: 12902477]

Kennedy MK, Glaccum M, Brown SN, Butz EA, Viney JL, Embers M, Matsuki N, Charrier K, Sedger L, Willis CR, Brasel K, Morrissey PJ, Stocking K, Schuh JCL, Joyce S, Peschon JJ. Reversible defects in natural killer and memory CD8 T cell lineages in interleukin 15- deficient mice. J Exp Med 2000;191:771-780. [PubMed: 10704459]

Kim JH, Choi EY, Chung DH. Donor bone marrow type II (non-Valpha14Jalpha18 CD1d-restricted) NKT cells suppress graft-versus-host disease by producing IFN-gamma and IL-4. J Immunol 2007;179:6579-87. [PubMed: 17982047]

Kim YJ, Ko HJ, Kim YS, Kim DH, Kang S, Kim JM, Chung Y, Kang CY. alpha-Galactosylceramideloaded, antigen-expressing B cells prime a wide spectrum of antitumor immunity. Int J Cancer 2008;122:2774-83. [PubMed: 18338753]

Kinjo Y, Tupin E, Wu D, Fujio M, Garcia-Navarro R, Benhnia MR, Zajonc DM, Ben-Menachem G, Ainge GD, Painter GF, Khurana A, Hoebe K, Behar SM, Beutler B, Wilson IA, Tsuji M, Sellati TJ, Wong CH, Kronenberg M. Natural killer T cells recognize diacylglycerol antigens from pathogenic bacteria. Nat Immunol 2006;7:978-86. [PubMed: 16921381] 
Kinjo Y, Wu D, Kim G, Xing GW, Poles MA, Ho DD, Tsuji M, Kawahara K, Wong CH, Kronenberg M. Recognition of bacterial glycosphingolipids by natural killer T cells. Nature 2005;434:520-5. [PubMed: 15791257]

Kitamura H, Iwakabe K, Yahata T, Nishimura S, Ohta A, Ohmi Y, Sato M, Takeda K, Okumura K, Van Kaer L, Kawano T, Taniguchi M, Nishimura T. The natural killer T (NKT) cell ligand alphagalactosylceramide demonstrates its immunopotentiating effect by inducing interleukin (IL)- 12 production by dendritic cells and IL-12 receptor expression on NKT cells. J Exp Med 1999;189:1121-8. [PubMed: 10190903]

Kitamura H, Ohta A, Sekimoto M, Sato M, Iwakabe K, Nakui M, Yahata T, Meng H, Koda T, Nishimura S, Kawano T, Taniguchi M, Nishimura T. alpha-galactosylceramide induces early B-cell activation through IL-4 production by NKT cells. Cell Immunol 2000;199:37-42. [PubMed: 10675273]

Ko SY, Ko HJ, Chang WS, Park SH, Kweon MN, Kang CY. alpha-Galactosylceramide can act as a nasal vaccine adjuvant inducing protective immune responses against viral infection and tumor. $\mathrm{J}$ Immunol 2005;175:3309-17. [PubMed: 16116223]

Kobayashi E, Motoki K, Uchida T, Fukushima H, Koezuka Y. KRN7000, a novel immunomodulator, and its antitumor activities. Oncol Res 1995;7:529-34. [PubMed: 8866665]

Kojo S, Adachi Y, Keino H, Taniguchi M, Sumida T. Dysfunction of T cell receptor AV24AJ18+, BV11 + double-negative regulatory natural killer T cells in autoimmune diseases. Arthritis Rheum 2001;44:1127-38. [PubMed: 11352245]

Koseki H, Imai K, Ichikawa T, Hayata I, Taniguchi M. Predominant use of a particular alpha-chain in suppressor T cell hybridomas specific for keyhole limpet hemocyanin. Int Immunol 1989;1:55764. [PubMed: 2562245]

Kronenberg M. Toward an understanding of NKT cell biology: progress and paradoxes. Annu Rev Immunol 2005;23:877-900. [PubMed: 15771592]

Kukreja A, Cost G, Marker J, Zhang C, Sun Z, Lin-Su K, Ten S, Sanz M, Exley M, Wilson B, Porcelli S, Maclaren N. Multiple immuno-regulatory defects in type-1 diabetes. J Clin Invest 2002;109:13140. [PubMed: 11781358]

Kulkarni AB, Huh CG, Becker D, Geiser A, Lyght M, Flanders KC, Roberts AB, Sporn MB, Ward JM, Karlsson S. Transforming growth factor beta 1 null mutation in mice causes excessive inflammatory response and early death. Proc Natl Acad Sci U S A 1993;90:770-4. [PubMed: 8421714]

Kumar H, Belperron A, Barthold SW, Bockenstedt LK. Cutting edge: CD1d deficiency impairs murine host defense against the spirochete, Borrelia burgdorferi. J Immunol 2000;165:4797-801. [PubMed: 11046002]

La Cava A, Van Kaer L, Fu Dong S. CD4+CD25+ Tregs and NKT cells: regulators regulating regulators. Trends Immunol 2006;27:322-7. [PubMed: 16735139]

Lan F, Zeng D, Higuchi M, Higgins JP, Strober S. Host conditioning with total lymphoid irradiation and antithymocyte globulin prevents graft-versus-host disease: the role of CD1-reactive natural killer T cells. Biol Blood Marrow Transplant 2003;9:355-63. [PubMed: 12813443]

Lan F, Zeng D, Higuchi M, Huie P, Higgins JP, Strober S. Predominance of NK1.1+TCR alpha beta+ or DX5+TCR alpha beta+ T cells in mice conditioned with fractionated lymphoid irradiation protects against graft-versus-host disease: "natural suppressor” cells. J Immunol 2001;167:2087-96. [PubMed: 11489992]

Lantz O, Bendelac A. An invariant T cell receptor alpha chain is used by a unique subset of major histocompatibility complex class I-specific CD4+ and CD4-8- T cells in mice and humans. J Exp Med 1994;180:1097-106. [PubMed: 7520467]

Lee PT, Benlagha K, Teyton L, Bendelac A. Distinct functional lineages of human Va24 natural killer cells. Journal of Experimental Medicine 2002a;195:637-41. [PubMed: 11877486]

Lee PT, Putnam A, Benlagha K, Teyton L, Gottlieb PA, Bendelac A. Testing the NKT cell hypothesis of human IDDM pathogenesis. J Clin Invest 2002b;110:793-800. [PubMed: 12235110]

Lees RK, Ferrero I, MacDonald HR. Tissue-specific segregation of TCRgamma delta+ NKT cells according to phenotype TCR repertoire and activation status: parallels with TCR alphabeta+NKT cells. Eur J Immunol 2001;31:2901-9. [PubMed: 11592065] 
Lehuen A, Lantz O, Beaudoin L, Laloux V, Carnaud C, Bendelac A, Bach JF, Monteiro RC. Overexpression of natural killer $\mathrm{T}$ cells protects Valpha14-Jalpha281 transgenic nonobese diabetic mice against diabetes. J Exp Med 1998;188:1831-9. [PubMed: 9815260]

Letterio JJ, Roberts AB. Regulation of immune responses by TGF-beta. Annu Rev Immunol 1998;16:137-61. [PubMed: 9597127]

Leveen P, Larsson J, Ehinger M, Cilio CM, Sundler M, Sjostrand LJ, Holmdahl R, Karlsson S. Induced disruption of the transforming growth factor beta type II receptor gene in mice causes a lethal inflammatory disorder that is transplantable. Blood 2002;100:560-8. [PubMed: 12091349]

Levitsky HI, Golumbek PT, Pardoll DM. The fate of CD4-8- T cell receptor-alpha beta+ thymocytes. J Immunol 1991;146:1113-7. [PubMed: 1825103]

Li W, Ji F, Zhang Y, Wang Y, Yang N, Ge H, Wang F. Cooperation of invariant NKT cells and CD4 $+\mathrm{CD} 25+\mathrm{T}$ regulatory cells in prevention of autoimmune diabetes in non-obese diabetic mice treated with alpha-galactosylceramide. Acta Biochim Biophys Sin (Shanghai) 2008;40:381-90. [PubMed: 18465023]

Lin H, Nieda M, Rozenkov V, Nicol AJ. Analysis of the effect of different NKT cell subpopulations on the activation of CD4 and CD8 T cells, NK cells, and B cells. Exp Hematol 2006;34:289-95. [PubMed: 16543063]

Liu K, Idoyaga J, Charalambous A, Fujii S, Bonito A, Mordoh J, Wainstok R, Bai XF, Liu Y, Steinman RM. Innate NKT lymphocytes confer superior adaptive immunity via tumor-capturing dendritic cells. J Exp Med 2005a;202:1507-16. [PubMed: 16330814]

Liu R, La Cava A, Bai XF, Jee Y, Price M, Campagnolo DI, Christadoss P, Vollmer TL, Van Kaer L, Shi FD. Cooperation of Invariant NKT Cells and CD4+CD25+ T Regulatory Cells in the Prevention of Autoimmune Myasthenia. J Immunol 2005b;175:7898-7904. [PubMed: 16339525]

Liu YJ. IPC: professional type 1 interferon-producing cells and plasmacytoid dendritic cell precursors. Annu Rev Immunol 2005;23:275-306. [PubMed: 15771572]

Lodolce JP, Boone DL, Chai S, Swain RE, Dassopoulos T, Trettin S, Ma A. IL-15 receptor maintains lymphoid homeostasis by supporting lymphocyte homing and proliferation. Immunity 1998;9:66976. [PubMed: 9846488]

Ly D, Mi QS, Hussain S, Delovitch TL. Protection from type 1 diabetes by invariant NK T cells requires the activity of CD4+CD25+ regulatory T cells. J Immunol 2006;177:3695-704. [PubMed: 16951329]

Macdonald HR. NKT cells: In the beginning. Eur J Immunol 2007;37(Suppl 1):S111-5. [PubMed: 17972354]

MacDonald HR, Mycko MP. Development and selection of Valpha 14i NKT cells. Curr Top Microbiol Immunol 2007;314:195-212. [PubMed: 17593662]

Makino Y, Kanno R, Ito T, Higashino K, Taniguchi M. Predominant expression of invariant V alpha 14 + TCR alpha chain in NK1.1+ T cell populations. Int Immunol 1995;7:1157-61. [PubMed: 8527413]

Mallevaey T, Fontaine J, Breuilh L, Paget C, Castro-Keller A, Vendeville C, Capron M, Leite-de-Moraes M, Trottein F, Faveeuw C. Invariant and Noninvariant Natural Killer T Cells Exert Opposite Regulatory Functions on the Immune Response during Murine Schistosomiasis. Infect Immun 2007;75:2171-80. [PubMed: 17353286]

Mars LT, Laloux V, Goude K, Desbois S, Saoudi A, Van Kaer L, Lassmann H, Herbelin A, Lehuen A, Liblau RS. Cutting edge: V alpha 14-J alpha 281 NKT cells naturally regulate experimental autoimmune encephalomyelitis in nonobese diabetic mice. J Immunol 2002;168:6007-11. [PubMed: 12055208]

Matsuda JL, Gapin L, Baron JL, Sidobre S, Stetson DB, Mohrs M, Locksley RM, Kronenberg M. Mouse $\mathrm{V}$ alpha 14i natural killer T cells are resistant to cytokine polarization in vivo. Proc Natl Acad Sci U S A 2003;100:8395-400. [PubMed: 12829795]

Matsuda JL, Naidenko OV, Gapin L, Nakayama T, Taniguchi M, Wang CR, Koezuka Y, Kronenberg $\mathrm{M}$. Tracking the response of natural killer $\mathrm{T}$ cells to a glycolipid antigen using CD1d tetramers. $\mathbf{J}$ Exp Med 2000;192:741-54. [PubMed: 10974039] 
Matsui S, Ahlers JD, Vortmeyer AO, Terabe M, Tsukui T, Carbone DP, Liotta LA, Berzofsky J. A model for CD8+ CTL tumor immunosurveillance and regulation of tumor escape by CD4 T cells through an effect on quality of CTL. J Immunol 1999;163:184-193. [PubMed: 10384115]

Mattner J, Debord KL, Ismail N, Goff RD, Cantu C 3rd, Zhou D, Saint-Mezard P, Wang V, Gao Y, Yin N, Hoebe K, Schneewind O, Walker D, Beutler B, Teyton L, Savage PB, Bendelac A. Exogenous and endogenous glycolipid antigens activate NKT cells during microbial infections. Nature 2005;434:525-9. [PubMed: 15791258]

McKenzie AN. Regulation of T helper type 2 cell immunity by interleukin- 4 and interleukin-13. Pharmacol Ther 2000;88:143-51. [PubMed: 11150594]

McNab FW, Pellicci DG, Field K, Besra G, Smyth MJ, Godfrey DI, Berzins SP. Peripheral NK1.1 NKT cells are mature and functionally distinct from their thymic counterparts. J Immunol 2007;179:6630-7. [PubMed: 17982053]

Metelitsa LS, Naidenko OV, Kant A, Wu HW, Loza MJ, Perussia B, Kronenberg M, Seeger RC. Human NKT cells mediate antitumor cytotoxicity directly by recognizing target cell CD1d with bound ligand or indirectly by producing IL-2 to activate NK cells. J Immunol 2001;167:3114-22. [PubMed: 11544296]

Meyer EH, Goya S, Akbari O, Berry GJ, Savage PB, Kronenberg M, Nakayama T, DeKruyff RH, Umetsu DT. Glycolipid activation of invariant T cell receptor+ NK T cells is sufficient to induce airway hyperreactivity independent of conventional CD4+ T cells. Proc Natl Acad Sci U S A 2006;103:2782-7. [PubMed: 16478801]

Michel ML, Keller AC, Paget C, Fujio M, Trottein F, Savage PB, Wong CH, Schneider E, Dy M, Leitede-Moraes MC. Identification of an IL-17-producing NK1.1(neg) iNKT cell population involved in airway neutrophilia. J Exp Med 2007;204:995-1001. [PubMed: 17470641]

Mirza N, Fishman M, Fricke I, Dunn M, Neuger AM, Frost TJ, Lush RM, Antonia S, Gabrilovich DI. All-trans-retinoic acid improves differentiation of myeloid cells and immune response in cancer patients. Cancer Res 2006;66:9299-307. [PubMed: 16982775]

Miyagi T, Takehara T, Tatsumi T, Kanto T, Suzuki T, Jinushi M, Sugimoto Y, Sasaki Y, Hori M, Hayashi N. CD1d-mediated stimulation of natural killer T cells selectively activates hepatic natural killer cells to eliminate experimentally disseminated hepatoma cells in murine liver. Int J Cancer 2003;106:81-9. [PubMed: 12794761]

Miyamoto K, Miyake S, Yamamura T. A synthetic glycolipid prevents autoimmune encephalomyelitis by inducing TH2 bias of natural killer T cells. Nature 2001;413:531-4. [PubMed: 11586362]

Miyamoto M, Emoto M, Brinkmann V, van Rooijen N, Schmits R, Kita E, Kaufmann SH. Cutting edge: contribution of NK cells to the homing of thymic CD4+NKT cells to the liver. J Immunol 2000;165:1729-32. [PubMed: 10925248]

Molling JW, Kolgen W, van der Vliet HJ, Boomsma MF, Kruizenga H, Smorenburg CH, Molenkamp BG, Langendijk JA, Leemans CR, von Blomberg BM, Scheper RJ, van den Eertwegh AJ. Peripheral blood IFN-gamma-secreting Valpha24+Vbeta11+ NKT cell numbers are decreased in cancer patients independent of tumor type or tumor load. Int J Cancer 2005;116:87-93. [PubMed: 15756674]

Molling JW, Langius JA, Langendijk JA, Leemans CR, Bontkes HJ, van der Vliet HJ, von Blomberg BM, Scheper RJ, van den Eertwegh AJ. Low levels of circulating invariant natural killer T cells predict poor clinical outcome in patients with head and neck squamous cell carcinoma. J Clin Oncol 2007;25:862-8. [PubMed: 17327607]

Molling JW, Moreno M, de Groot J, van der Vliet HJ, von Blomberg BM, van den Eertwegh AJ, Scheper RJ, Bontkes HJ. Chronically stimulated mouse invariant NKT cell lines have a preserved capacity to enhance protection against experimental tumor metastases. Immunol Lett 2008;118:36-43. [PubMed: 18405982]

Montoya CJ, Jie HB, Al-Harthi L, Mulder C, Patino PJ, Rugeles MT, Krieg AM, Landay AL, Wilson SB. Activation of plasmacytoid dendritic cells with TLR9 agonists initiates invariant NKT cellmediated cross-talk with myeloid dendritic cells. J Immunol 2006;177:1028-39. [PubMed: 16818759]

Moodycliffe AM, Nghiem D, Clydesdale G, Ullrich SE. Immune suppression and skin cancer development: regulation by NKT cells. Nat Immunol 2000;1:521-5. [PubMed: 11101875] 
Morita M, Motoki K, Akimoto K, Natori T, Sakai T, Sawa E, Yamaji K, Koezuka Y, Kobayashi E, Fukushima H. Structure-activity relationship of alpha-galactosylceramides against B16-bearing mice. J Med Chem 1995;38:2176-87. [PubMed: 7783149]

Morris JC, Shapiro GI, Tan AR, Lawrence DP, Olencki TE, Dezube BJ, Hsu FJ, Reiss M, Berzofsky JA. Phase I/II Study of GC1008: A human anti-transforming growth factor-beta (TGFb) monoclonal antibody (MAb) in patients with advanced malignant melanoma (MM) or renal cell carcinoma (RCC). J Clin Oncol 2008;26:489.

Motohashi S, Ishikawa A, Ishikawa E, Otsuji M, Iizasa T, Hanaoka H, Shimizu N, Horiguchi S, Okamoto Y, Fujii S, Taniguchi M, Fujisawa T, Nakayama T. A phase I study of in vitro expanded natural killer T cells in patients with advanced and recurrent non-small cell lung cancer. Clin Cancer Res 2006;12:6079-86. [PubMed: 17028247]

Motoki K, Morita M, Kobayashi E, Uchida T, Akimoto K, Fukushima H, Koezuka Y. Immunostimulatory and antitumor activities of monoglycosylceramides having various sugar moieties. Biol Pharm Bull 1995;18:1487-91. [PubMed: 8593464]

Muhlen KA, Schumann J, Wittke F, Stenger S, Van Rooijen N, Van Kaer L, Tiegs G. NK cells, but not NKT cells, are involved in Pseudomonas aeruginosa exotoxin A-induced hepatotoxicity in mice. $\mathrm{J}$ Immunol 2004;172:3034-41. [PubMed: 14978108]

Murata T, Obiri NI, Puri RK. Structure of and signal transduction through interleukin-4 and interleukin-13 receptors (review). Int J Mol Med 1998;1:551-7. [PubMed: 9852261]

Nagaraj S, Ziske C, Strehl J, Messmer D, Sauerbruch T, Schmidt-Wolf IG. Dendritic cells pulsed with alpha-galactosylceramide induce anti-tumor immunity against pancreatic cancer in vivo. Int Immunol 2006;18:1279-83. [PubMed: 16772371]

Nakui M, Ohta A, Sekimoto M, Sato M, Iwakabe K, Yahata T, Kitamura H, Koda T, Kawano T, Makuuchi H, Taniguchi M, Nishimura T. Potentiation of antitumor effect of NKT cell ligand, alphagalactosylceramide by combination with IL-12 on lung metastasis of malignant melanoma cells. Clin Exp Metastasis 2000;18:147-53. [PubMed: 11235990]

Nam JS, Terabe M, Kang MJ, Chae H, Voong N, Yang YA, Laurence A, Michalowska A, Mamura M, Lonning S, Berzofsky JA, Wakefield LM. Transforming Growth Factor \{beta\} Subverts the Immune System into Directly Promoting Tumor Growth through Interleukin-17. Cancer Res 2008;68:3915-23. [PubMed: 18483277]

Naumov YN, Bahjat KS, Gausling R, Abraham R, Exley MA, Koezuka Y, Balk SB, Strominger JL, Clare-Salzer M, Wilson SB. Activation of CD1d-restricted T cells protects NOD mice from developing diabetes by regulating dendritic cell subsets. Proc Natl Acad Sci U S A 2001;98:1383843. [PubMed: 11707602]

Nichols KE, Hom J, Gong SY, Ganguly A, Ma CS, Cannons JL, Tangye SG, Schwartzberg PL, Koretzky GA, Stein PL. Regulation of NKT cell development by SAP, the protein defective in XLP. Nat Med 2005;11:340-5. [PubMed: 15711562]

Nicol A, Nieda M, Koezuka Y, Porcelli S, Suzuki K, Tadokoro K, Durrant S, Juji T. Dendritic cells are targets for human invariant Valpha24+ natural killer T-cell cytotoxic activity: an important immune regulatory function. Exp Hematol 2000;28:276-82. [PubMed: 10720692]

Nieda M, Okai M, Tazbirkova A, Lin H, Yamaura A, Ide K, Abraham R, Juji T, Macfarlane DJ, Nicol AJ. Therapeutic activation of Valpha24+Vbeta11+ NKT cells in human subjects results in highly coordinated secondary activation of acquired and innate immunity. Blood 2004;103:383-9. [PubMed: 14512316]

Nieuwenhuis EE, Matsumoto T, Exley M, Schleipman RA, Glickman J, Bailey DT, Corazza N, Colgan $\mathrm{SP}$, Onderdonk AB, Blumberg RS. CD1d-dependent macrophage-mediated clearance of Pseudomonas aeruginosa from lung. Nat Med 2002;8:588-93. [PubMed: 12042809]

Nishikawa H, Kato T, Tanida K, Hiasa A, Tawara I, Ikeda H, Ikarashi Y, Wakasugi H, Kronenberg M, Nakayama T, Taniguchi M, Kuribayashi K, Old LJ, Shiku H. CD4+ CD25+ T cells responding to serologically defined autoantigens suppress antitumor immune responses. Proc Natl Acad Sci U S A 2003;100:10902-6. [PubMed: 12947044]

Nishimura T, Kitamura H, Iwakabe K, Yahata T, Ohta A, Sato M, Takeda K, Okumura K, Van Kaer L, Kawano T, Taniguchi M, Nakui M, Sekimoto M, Koda T. The interface between innate and acquired immunity: glycolipid antigen presentation by CD1d-expressing dendritic cells to NKT cells induces 
the differentiation of antigen-specific cytotoxic T lymphocytes. Int Immunol 2000;12:987-94. [PubMed: 10882410]

Nowak M, Stein-Streilein J. Invariant NKT cells and tolerance. Int Rev Immunol 2007;26:95-119. [PubMed: 17454266]

Ohteki T, Ho S, Suzuki H, Mak TW, Ohashi PS. Role for IL-15/IL-15 receptor beta-chain in natural killer 1.1+ T cell receptor-alpha beta+ cell development. J Immunol 1997;159:5931-5. [PubMed: 9550390]

Ohteki T, MacDonald HR. Major histocompatibility complex class I related molecules control the development of CD4+8- and CD4-8- subsets of natural killer 1.1+ T cell receptor-alpha/beta+ cells in the liver of mice. J Exp Med 1994;180:699-704. [PubMed: 8046344]

Okai M, Nieda M, Tazbirkova A, Horley D, Kikuchi A, Durrant S, Takahashi T, Boyd A, Abraham R, Yagita H, Juji T, Nicol A. Human peripheral blood Valpha24+ Vbeta11+ NKT cells expand following administration of alpha-galactosylceramide-pulsed dendritic cells. Vox Sang 2002;83:250-3. [PubMed: 12366768]

Oki S, Chiba A, Yamamura T, Miyake S. The clinical implication and molecular mechanism of preferential IL-4 production by modified glycolipid-stimulated NKT cells. J Clin Invest 2004;113:1631-40. [PubMed: 15173890]

Onizuka S, Tawara I, Shimizu J, Sakaguchi S, Fujita T, Nakayama E. Tumor rejection by in vivo administration of anti-CD25 (interleukin-2 receptor alpha) monoclonal antibody. Cancer Res 1999;59:3128-33. [PubMed: 10397255]

Ortaldo JR, Young HA, Winkler-Pickett RT, Bere EW Jr, Murphy WJ, Wiltrout RH. Dissociation of NKT stimulation, cytokine induction, and NK activation in vivo by the use of distinct TCR-binding ceramides. J Immunol 2004;172:943-53. [PubMed: 14707067]

Osada T, Morse MA, Lyerly HK, Clay TM. Ex vivo expanded human CD4+ regulatory NKT cells suppress expansion of tumor antigen-specific CTLs. Int Immunol 2005;17:1143-55. [PubMed: 16027139]

Ostrand-Rosenberg S, Clements VK, Terabe M, Park JM, Berzofsky J, Dissanayake SK. Resistance to metastatic disease in Stat6-deficient mice requires hematopoietic and non-hematopoietic cells and is IFN $\gamma$-dependent. Journal of Immunol 2002;169:5796-5804. [PubMed: 12421960]

Ostrand-Rosenberg S, Grusby MJ, Clements VK. Cutting Edge: STAT6-Deficient Mice Have Enhanced Tumor Immunity to Primary and Metastatic Mammary Carcinoma. J Immunol 2000;165:60156019. [PubMed: 11086031]

Paget C, Mallevaey T, Speak AO, Torres D, Fontaine J, Sheehan KC, Capron M, Ryffel B, Faveeuw C, Leite de Moraes M, Platt F, Trottein F. Activation of invariant NKT cells by toll-like receptor 9stimulated dendritic cells requires type I interferon and charged glycosphingolipids. Immunity 2007;27:597-609. [PubMed: 17950005]

Pak AS, Wright MA, Matthews JP, Collins SL, Petruzzelli GJ, Young MR. Mechanisms of immune suppression in patients with head and neck cancer: presence of CD34(+) cells which suppress immune functions within cancers that secrete granulocyte-macrophage colony-stimulating factor. Clin Cancer Res 1995;1:95-103. [PubMed: 9815891]

Pardoll DM. Spinning molecular immunology into successful immunotherapy. Nat Rev Immunol 2002;2:227-38. [PubMed: 12001994]

Park JM, Terabe M, Donaldson DD, Forni G, Berzofsky JA. Natural immunosurveillance against spontaneous, autochthonous breast cancers revealed and enhanced by blockade of IL-13-mediated negative regulation. Cancer Immunol Immunother 2008;57:907-912. [PubMed: 18004566]

Park JM, Terabe M, van den Broeke LT, Donaldson DD, Berzofsky JA. Unmasking immunosurveillance against a syngeneic colon cancer by elimination of CD4+ NKT regulatory cells and IL-13. International J of Cancer 2004;114:80-87.

Park SH, Kyin T, Bendelac A, Carnaud C. The contribution of NKT cells, NK cells, and other gammachain-dependent non-T non-B cells to IL-12-mediated rejection of tumors. J Immunol 2003;170:1197-201. [PubMed: 12538676]

Park SH, Weiss A, Benlagha K, Kyin T, Teyton L, Bendelac A. The mouse CD1d-restricted repertoire is dominated by a few autoreactive T cell receptor families. J Exp Med 2001;193:893-904.

[PubMed: 11304550] 
Pasquier B, Yin L, Fondaneche MC, Relouzat F, Bloch-Queyrat C, Lambert N, Fischer A, de Saint-Basile G, Latour S. Defective NKT cell development in mice and humans lacking the adapter SAP, the Xlinked lymphoproliferative syndrome gene product. J Exp Med 2005;201:695-701. [PubMed: 15738056]

Pellicci DG, Hammond KJ, Coquet J, Kyparissoudis K, Brooks AG, Kedzierska K, Keating R, Turner S, Berzins S, Smyth MJ, Godfrey DI. DX5/CD49b-positive T cells are not synonymous with CD1ddependent NKT cells. J Immunol 2005;175:4416-25. [PubMed: 16177083]

Pillai AB, George TI, Dutt S, Teo P, Strober S. Host NKT cells can prevent graft-versus-host disease and permit graft antitumor activity after bone marrow transplantation. J Immunol 2007;178:6242-51. [PubMed: 17475852]

Porcelli S, Yockey CE, Brenner MB, Balk SP. Analysis of T cell antigen receptor (TCR) expression by human peripheral blood CD4-8- alpha/beta T cells demonstrates preferential use of several V beta genes and an invariant TCR alpha chain. J Exp Med 1993;178:1-16. [PubMed: 8391057]

Porubsky S, Speak AO, Luckow B, Cerundolo V, Platt FM, Grone HJ. Normal development and function of invariant natural killer T cells in mice with isoglobotrihexosylceramide (iGb3) deficiency. Proc Natl Acad Sci U S A 2007;104:5977-82. [PubMed: 17372206]

Rachitskaya AV, Hansen AM, Horai R, Li Z, Villasmil R, Luger D, Nussenblatt RB, Caspi RR. Cutting edge: NKT cells constitutively express IL-23 receptor and RORgammat and rapidly produce IL-17 upon receptor ligation in an IL-6-independent fashion. J Immunol 2008;180:5167-71. [PubMed: 18390697]

Rauch J, Gumperz J, Robinson C, Skold M, Roy C, Young DC, Lafleur M, Moody DB, Brenner MB, Costello CE, Behar SM. Structural features of the acyl chain determine self-phospholipid antigen recognition by a CD1d-restricted invariant NKT (iNKT) cell. J Biol Chem 2003;278:47508-15. [PubMed: 12963715]

Renukaradhya GJ, Khan MA, Vieira M, Du W, Gervay-Hague J, Brutkiewicz RR. Type I NKT cells protect (and type II NKT cells suppress) the host's innate antitumor immune response to a B-cell lymphoma. Blood 2008;111:5637-45. [PubMed: 18417738]

Renukaradhya GJ, Sriram V, Du W, Gervay-Hague J, Van Kaer L, Brutkiewicz RR. Inhibition of antitumor immunity by invariant natural killer T cells in a T-cell lymphoma model in vivo. Int $\mathbf{J}$ Cancer 2006;118:3045-3053. [PubMed: 16395717]

Roark JH, Park SH, Jayawardena J, Kavita U, Shannon M, Bendelac A. CD1.1 expression by mouse antigen-presenting cells and marginal zone B cells. J Immunol 1998;160:3121-7. [PubMed: 9531266]

Roberts DD. Sulfatide-binding proteins. Chem Phys Lipids 1986;42:173-83. [PubMed: 3549017]

Roelofs-Haarhuis K, Wu X, Nowak M, Fang M, Artik S, Gleichmann E. Infectious nickel tolerance: a reciprocal interplay of tolerogenic APCs and T suppressor cells that is driven by immunization. $\mathrm{J}$ Immunol 2003;171:2863-72. [PubMed: 12960308]

Roy KC, Maricic I, Khurana A, Smith TR, Halder RC, Kumar V. Involvement of secretory and endosomal compartments in presentation of an exogenous self-glycolipid to type II NKT cells. J Immunol 2008;180:2942-50. [PubMed: 18292516]

Sagiv Y, Bai L, Wei DG, Agami R, Savage PB, Teyton L, Bendelac A. A distal effect of microsomal triglyceride transfer protein deficiency on the lysosomal recycling of CD1d. J Exp Med 2007;204:921-8. [PubMed: 17403933]

Sakaguchi S. Naturally arising CD4+ regulatory t cells for immunologic self-tolerance and negative control of immune responses. Annu Rev Immunol 2004;22:531-62. [PubMed: 15032588]

Salio M, Speak AO, Shepherd D, Polzella P, Illarionov PA, Veerapen N, Besra GS, Platt FM, Cerundolo V. Modulation of human natural killer T cell ligands on TLR-mediated antigen-presenting cell activation. Proc Natl Acad Sci U S A 2007;104:20490-5. [PubMed: 18077358]

Schmidt-Supprian M, Tian J, Grant EP, Pasparakis M, Maehr R, Ovaa H, Ploegh HL, Coyle AJ, Rajewsky K. Differential dependence of CD4+CD25+ regulatory and natural killer-like T cells on signals leading to NF-kappaB activation. Proc Natl Acad Sci U S A 2004;101:4566-71. [PubMed: 15070758] 
Schmieg J, Yang G, Franck RW, Tsuji M. Superior protection against malaria and melanoma metastases by a C-glycoside analogue of the natural killer T cell ligand alpha-Galactosylceramide. J Exp Med 2003;198:1631-41. [PubMed: 14657217]

Schmielau J, Finn OJ. Activated granulocytes and granulocyte-derived hydrogen peroxide are the underlying mechanism of suppression of T-cell function in advanced cancer patients. Cancer Res 2001;61:4756-60. [PubMed: 11406548]

Sfondrini L, Besusso D, Zoia MT, Rodolfo M, Invernizzi AM, Taniguchi M, Nakayama T, Colombo MP, Menard S, Balsari A. Absence of the CD1 molecule up-regulates antitumor activity induced by CpG oligodeoxynucleotides in mice. J Immunol 2002;169:151-8. [PubMed: 12077240]

Shamshiev A, Donda A, Carena I, Mori L, Kappos L, De Libero G. Self glycolipids as T-cell autoantigens. Eur J Immunol 1999;29:1667-75. [PubMed: 10359121]

Shamshiev A, Gober HJ, Donda A, Mazorra Z, Mori L, De Libero G. Presentation of the same glycolipid by different CD1 molecules. J Exp Med 2002;195:1013-21. [PubMed: 11956292]

Sharif S, Arreaza GA, Zucker P, Mi QS, Sondhi J, Naidenko OV, Kronenberg M, Koezuka Y, Delovitch TL, Gombert JM, Leite-De-Moraes M, Gouarin C, Zhu R, Hameg A, Nakayama T, Taniguchi M, Lepault F, Lehuen A, Bach JF, Herbelin A. Activation of natural killer T cells by alphagalactosylceramide treatment prevents the onset and recurrence of autoimmune Type 1 diabetes. Nat Med 2001;7:1057-62. [PubMed: 11533711]

Shimamura M, Huang YY. Presence of a novel subset of NKT cells bearing an invariant V(alpha)19.1J(alpha)26 TCR alpha chain. FEBS Lett 2002;516:97-100. [PubMed: 11959111]

Shimizu J, Yamazaki S, Sakaguchi S. Induction of tumor immunity by removing CD25+ CD4+ T cells: a common basis between tumor immunity and autoimmunity. J Immunol 1999;163:5211-5218. [PubMed: 10553041]

Shimizu K, Goto A, Fukui M, Taniguchi M, Fujii S. Tumor cells loaded with alpha-galactosylceramide induce innate NKT and NK cell-dependent resistance to tumor implantation in mice. J Immunol 2007a;178:2853-61. [PubMed: 17312129]

Shimizu K, Kurosawa Y, Taniguchi M, Steinman RM, Fujii S. Cross-presentation of glycolipid from tumor cells loaded with alpha-galactosylceramide leads to potent and long-lived T cell mediated immunity via dendritic cells. J Exp Med 2007b;204:2641-53. [PubMed: 17923500]

Shull MM, Ormsby I, Kier AB, Pawlowski S, Diebold RJ, Yin M, Allen R, Sidman C, Proetzel G, Calvin $\mathrm{D}$, Annunziata N, Doetschman T. Targeted disruption of the mouse transforming growth factor-b1 gene results in multifocal inflammatory disease. Nature 1992;359:693-0. [PubMed: 1436033]

Silk JD, Hermans IF, Gileadi U, Chong TW, Shepherd D, Salio M, Mathew B, Schmidt RR, Lunt SJ, Williams KJ, Stratford IJ, Harris AL, Cerundolo V. Utilizing the adjuvant properties of CD1ddependent NK T cells in T cell-mediated immunotherapy. J Clin Invest 2004;114:1800-11. [PubMed: 15599405]

Silk JD, Salio M, Reddy BG, Shepherd D, Gileadi U, Brown J, Masri SH, Polzella P, Ritter G, Besra GS, Jones EY, Schmidt RR, Cerundolo V. Cutting edge: nonglycosidic CD1d lipid ligands activate human and murine invariant NKT cells. J Immunol 2008;180:6452-6. [PubMed: 18453560]

Sinha P, Clements VK, Ostrand-Rosenberg S. Interleukin-13-regulated M2 macrophages in combination with myeloid suppressor cells block immune surveillance against metastasis. Cancer Res 2005a; 65:11743-51. [PubMed: 16357187]

Sinha P, Clements VK, Ostrand-Rosenberg S. Reduction of myeloid-derived suppressor cells and induction of M1 macrophages facilitate the rejection of established metastatic disease. J Immunol 2005b;174:636-45. [PubMed: 15634881]

Sivakumar V, Hammond KJ, Howells N, Pfeffer K, Weih F. Differential requirement for Rel/nuclear factor kappa B family members in natural killer T cell development. J Exp Med 2003;197:161321. [PubMed: 12810684]

Skinnider BF, Elia AJ, Gascoyne RD, Patterson B, Trumper L, Kapp U, Mak TW. Signal transducer and activator of transcription 6 is frequently activated in Hodgkin and Reed-Sternberg cells of Hodgkin lymphoma. Blood 2002a;99:618-26. [PubMed: 11781246]

Skinnider BF, Elia AJ, Gascoyne RD, Trumper LH, von Bonin F, Kapp U, Patterson B, Snow BE, Mak TW. Interleukin 13 and interleukin 13 receptor are frequently expressed by hodgkin and reedsternberg cells of hodgkin lymphoma. Blood 2001;97:250-5. [PubMed: 11133768] 
Skinnider BF, Kapp U, Mak TW. The role of interleukin 13 in classical Hodgkin lymphoma. Leuk Lymphoma 2002b;43:1203-10. [PubMed: 12152987]

Skold M, Faizunnessa NN, Wang CR, Cardell S. CD1d-specific NK1.1+ T cells with a transgenic variant TCR. J Immunol 2000;165:168-74. [PubMed: 10861049]

Slifka MK, Pagarigan RR, Whitton JL. NK markers are expressed on a high percentage of virus-specific CD8+ and CD4+ T cells. J Immunol 2000;164:2009-15. [PubMed: 10657652]

Smyth MJ, Crowe NY, Godfrey DI. NK cells and NKT cells collaborate in host protection from methylcholanthrene-induced fibrosarcoma. Int Immunol 2001;13:459-63. [PubMed: 11282985]

Smyth MJ, Crowe NY, Pellicci DG, Kyparissoudis K, Kelly JM, Takeda K, Yagita H, Godfrey DI. Sequential production of interferon-gamma by NK1.1(+) T cells and natural killer cells is essential for the antimetastatic effect of alpha-galactosylceramide. Blood 2002;99:1259-66. [PubMed: 11830474]

Smyth MJ, Godfrey DI. NKT cells and tumor immunity--a double-edged sword. Nat Immunol 2000;1:459-60. [PubMed: 11101862]

Smyth MJ, Taniguchi M, Street SE. The anti-tumor activity of IL-12: mechanisms of innate immunity that are model and dose dependent. J Immunol 2000a;165:2665-70. [PubMed: 10946296]

Smyth MJ, Thia KY, Street SE, Cretney E, Trapani JA, Taniguchi M, Kawano T, Pelikan SB, Crowe NY, Godfrey DI. Differential tumor surveillance by natural killer (NK) and NKT cells. J Exp Med 2000b;191:661-8. [PubMed: 10684858]

Smyth MJ, Wallace ME, Nutt SL, Yagita H, Godfrey DI, Hayakawa Y. Sequential activation of NKT cells and NK cells provides effective innate immunotherapy of cancer. J Exp Med 2005;201:197385. [PubMed: 15967825]

Sonoda KH, Exley M, Snapper S, Balk SP, Stein-Streilein J. CD1-reactive natural killer T cells are required for development of systemic tolerance through an immune-privileged site [see comments]. J Exp Med 1999;190:1215-26. [PubMed: 10544194]

Sonoda KH, Faunce DE, Taniguchi M, Exley M, Balk S, Stein-Streilein J. NK T cell-derived IL-10 is essential for the differentiation of antigen- specific T regulatory cells in systemic tolerance. $\mathrm{J}$ Immunol 2001;166:42-50. [PubMed: 11123275]

Sonoda KH, Stein-Streilein J. CD1d on antigen-transporting APC and splenic marginal zone B cells promotes NKT cell-dependent tolerance. Eur J Immunol 2002;32:848-57. [PubMed: 11870629]

Sonoda KH, Taniguchi M, Stein-Streilein J. Long-term survival of corneal allografts is dependent on intact CD1d-reactive NKT cells. J Immunol 2002;168:2028-34. [PubMed: 11823540]

Spada FM, Koezuka Y, Porcelli SA. CD1d-restricted recognition of synthetic glycolipid antigens by human natural killer T cells. J Exp Med 1998;188:1529-34. [PubMed: 9782130]

Speak AO, Salio M, Neville DC, Fontaine J, Priestman DA, Platt N, Heare T, Butters TD, Dwek RA, Trottein F, Exley MA, Cerundolo V, Platt FM. Implications for invariant natural killer T cell ligands due to the restricted presence of isoglobotrihexosylceramide in mammals. Proc Natl Acad Sci U S A 2007;104:5971-6. [PubMed: 17372214]

Sriram V, Du W, Gervay-Hague J, Brutkiewicz RR. Cell wall glycosphingolipids of Sphingomonas paucimobilis are CD1d-specific ligands for NKT cells. Eur J Immunol 2005;35:1692-701. [PubMed: 15915536]

Stanic AK, Bezbradica JS, Park JJ, Matsuki N, Mora AL, Van Kaer L, Boothby MR, Joyce S. NF-kappa B controls cell fate specification, survival, and molecular differentiation of immunoregulatory natural T lymphocytes. J Immunol 2004;172:2265-73. [PubMed: 14764695]

Stetson DB, Mohrs M, Reinhardt RL, Baron JL, Wang ZE, Gapin L, Kronenberg M, Locksley RM. Constitutive cytokine mRNAs mark natural killer (NK) and NK T cells poised for rapid effector function. J Exp Med 2003;198:1069-76. [PubMed: 14530376]

Stewart TJ, Smyth MJ, Fernando GJ, Frazer IH, Leggatt GR. Inhibition of early tumor growth requires J alpha 18-positive (natural killer T) cells. Cancer Res 2003;63:3058-60. [PubMed: 12810627]

Stirnemann K, Romero JF, Baldi L, Robert B, Cesson V, Besra GS, Zauderer M, Wurm F, Corradin G, Mach JP, Macdonald HR, Donda A. Sustained activation and tumor targeting of NKT cells using a CD1d-anti-HER2-scFv fusion protein induce antitumor effects in mice. J Clin Invest 2008;118:994-1005. [PubMed: 18259610] 
Stober D, Jomantaite I, Schirmbeck R, Reimann J. NKT cells provide help for dendritic cell-dependent priming of MHC class I-restricted CD8+ T cells in vivo. J Immunol 2003;170:2540-8. [PubMed: 12594280]

Street SE, Cretney E, Smyth MJ. Perforin and interferon-gamma activities independently control tumor initiation, growth, and metastasis. Blood 2001;97:192-7. [PubMed: 11133760]

Subleski JJ, Hall VL, Back TC, Ortaldo JR, Wiltrout RH. Enhanced antitumor response by divergent modulation of natural killer and natural killer T cells in the liver. Cancer Res 2006;66:11005-12. [PubMed: 17108139]

Sugawara I, Yamada H, Mizuno S, Li CY, Nakayama T, Taniguchi M. Mycobacterial infection in natural killer T cell knockout mice. Tuberculosis (Edinb) 2002;82:97-104. [PubMed: 12356461]

Sumida T, Sakamoto A, Murata H, Makino Y, Takahashi H, Yoshida S, Nishioka K, Iwamoto I, Taniguchi M. Selective reduction of T cells bearing invariant V alpha 24J alpha Q antigen receptor in patients with systemic sclerosis. J Exp Med 1995;182:1163-8. [PubMed: 7561690]

Sutmuller RPM, Van Duivenvoorde LM, Van Elsas A, Schumacher TNM, Wildenberg ME, Allison JP, Toes REM, Offringa R, Melief CJM. Synergism of cytotoxic T lymphocyte-associated antigen 4 blockade and depletion of CD25+ regulatory T cells in antitumor therapy reveals alternative cytotoxic T lymphocyte responses. J Exp Med 2001;194:823-832. [PubMed: 11560997]

Sykes M. Unusual T cell populations in adult murine bone marrow. Prevalence of CD3+CD4-CD8- and alpha beta TCR+NK1.1+ cells. J Immunol 1990;145:3209-15. [PubMed: 1977798]

Szabo SJ, Kim ST, Costa GL, Zhang X, Fathman CG, Glimcher LH. A novel transcription factor, T-bet, directs Th1 lineage commitment. Cell 2000;100:655-69. [PubMed: 10761931]

Tachibana T, Onodera H, Tsuruyama T, Mori A, Nagayama S, Hiai H, Imamura M. Increased intratumor Valpha24-positive natural killer T cells: a prognostic factor for primary colorectal carcinomas. Clin Cancer Res 2005;11:7322-7. [PubMed: 16243803]

Tahir SM, Cheng O, Shaulov A, Koezuka Y, Bubley GJ, Wilson SB, Balk SP, Exley MA. Loss of IFNgamma production by invariant NK T cells in advanced cancer. J Immunol 2001;167:4046-50. [PubMed: 11564825]

Takahama Y, Kosugi A, Singer A. Phenotype, ontogeny, and repertoire of CD4-CD8- T cell receptor alpha beta + thymocytes. Variable influence of self-antigens on $\mathrm{T}$ cell receptor $\mathrm{V}$ beta usage. $\mathrm{J}$ Immunol 1991;15:1134-1141. [PubMed: 1825105]

Takahama Y, Singer A. Post-transcriptional regulation of early T cell development by T cell receptor signals. Science 1992;258:1456-62. [PubMed: 1439838]

Takeda K, Hayakawa Y, Atsuta M, Hong S, Van Kaer L, Kobayashi K, Ito M, Yagita H, Okumura K. Relative contribution of NK and NKT cells to the anti-metastatic activities of IL-12. Int Immunol 2000a;12:909-14. [PubMed: 10837418]

Takeda K, Hayakawa Y, Van Kaer L, Matsuda H, Yagita H, Okumura K. Critical contribution of liver natural killer T cells to a murine model of hepatitis. Proc Natl Acad Sci U S A 2000b;97:5498-503. [PubMed: 10792025]

Tamada K, Harada M, Abe K, Li T, Tada H, Onoe Y, Nomoto K. Immunosuppressive activity of cloned natural killer (NK1.1+) T cells established from murine tumor-infiltrating lymphocytes. J Immunol 1997;158:4846-54. [PubMed: 9144500]

Taniguchi M, Harada M, Kojo S, Nakayama T, Wakao H. The regulatory role of Valpha14 NKT cells in innate and acquired immune response. Annu Rev Immunol 2003;21:483-513. [PubMed: 12543936]

Taniguchi M, Koseki H, Tokuhisa T, Masuda K, Sato H, Kondo E, Kawano T, Cui J, Perkes A, Koyasu $\mathrm{S}$, Makino Y. Essential requirement of an invariant V alpha $14 \mathrm{~T}$ cell antigen receptor expression in the development of natural killer T cells. Proc Natl Acad Sci U S A 1996;93:11025-8. [PubMed: 8855302]

Teicher BA. Transforming growth factor-beta and the immune response to malignant disease. Clin Cancer Res 2007;13:6247-51. [PubMed: 17975134]

Teng MW, Westwood JA, Darcy PK, Sharkey J, Tsuji M, Franck RW, Porcelli SA, Besra GS, Takeda K, Yagita H, Kershaw MH, Smyth MJ. Combined natural killer T-cell based immunotherapy eradicates established tumors in mice. Cancer Res 2007;67:7495-504. [PubMed: 17671220]

Terabe M, Berzofsky JA. Immunoregulatory T cells in tumor immunity. Current Opinion in Immunology 2004;16:157-162. [PubMed: 15023407] 
Terabe M, Berzofsky JA. NKT cells in immunoregulation of tumor immunity: a new immunoregulatory axis. Trends Immunol 2007;28:491-6. [PubMed: 17964217]

Terabe M, Khanna C, Bose S, Melchionda F, Mendoza A, Mackall CL, Helman L, Berzofsky JA. CD1drestricted NKT cells can down-regulate tumor immunosurveillance independent of IL-4R-STAT6 or TGF- $\beta$. Cancer Research 2006;66:3869-75. [PubMed: 16585215]

Terabe M, Matsui S, Noben-Trauth N, Chen H, Watson C, Donaldson DD, Carbone DP, Paul WE, Berzofsky JA. NKT cell-mediated repression of tumor immunosurveillance by IL-13 and the IL-4RSTAT6 pathway. Nature Immunology 2000;1:515-520. [PubMed: 11101874]

Terabe M, Matsui S, Park JM, Mamura M, Noben-Trauth N, Donaldson DD, Chen W, Wahl SM, Ledbetter S, Pratt B, Letterio JJ, Paul WE, Berzofsky JA. Transforming Growth Factor- $\beta$ production and myeloid cells are an effector mechanism through which CD1d-restricted T cells block Cytotoxic T Lymphocyte-mediated tumor immunosurveillance: abrogation prevents tumor recurrence. J Exp Med 2003a;198:1741-1752. [PubMed: 14657224]

Terabe M, Park JM, Berzofsky JA. Role of IL-13 in negative regulation of anti-tumor immunity. Cancer Immunol and Immunotherapy 2003b;53:79-85.

Terabe M, Swann J, Ambrosino E, Sinha P, Takaku S, Hayakawa Y, Godfrey DI, Ostrand-Rosenberg S, Smyth MJ, Berzofsky JA. A nonclassical non-Va14Ja18 CD1d-restricted (type II) NKT cell is sufficient for down-regulation of tumor immunosurveillance. J Exp Med 2005;202:1627-1633. [PubMed: 16365146]

Terabe M, Tagaya Y, Zhu Q, Granger L, Roederer M, Waldmann TA, Berzofsky JA. IL-15 Expands Unconventional CD8\{alpha\} \{alpha\}NK1.1+ T Cells but Not V\{alpha\}14J\{alpha\}18+ NKT Cells. J Immunol 2008;180:7276-86. [PubMed: 18490727]

Thomas SY, Lilly CM, Luster AD. Invariant natural killer T cells in bronchial asthma. N Engl J Med 2006;354:2613-6. [PubMed: 16775244] author reply 2613-6

Toura I, Kawano T, Akutsu Y, Nakayama T, Ochiai T, Taniguchi M. Cutting edge: inhibition of experimental tumor metastasis by dendritic cells pulsed with alpha-galactosylceramide. J Immunol 1999;163:2387-91. [PubMed: 10452972]

Townsend MJ, Weinmann AS, Matsuda JL, Salomon R, Farnham PJ, Biron CA, Gapin L, Glimcher LH. T-bet regulates the terminal maturation and homeostasis of NK and Valpha14i NKT cells. Immunity 2004;20:477-94. [PubMed: 15084276]

Treiner E, Duban L, Bahram S, Radosavljevic M, Wanner V, Tilloy F, Affaticati P, Gilfillan S, Lantz O. Selection of evolutionarily conserved mucosal-associated invariant $\mathrm{T}$ cells by MR1. Nature 2003;422:164-9. [PubMed: 12634786]

Trieu Y, Wen XY, Skinnider BF, Bray MR, Li Z, Claudio JO, Masih-Khan E, Zhu YX, Trudel S, McCart JA, Mak TW, Stewart AK. Soluble interleukin-13Ralpha2 decoy receptor inhibits Hodgkin's lymphoma growth in vitro and in vivo. Cancer Res 2004;64:3271-5. [PubMed: 15126369]

Tupin E, Kinjo Y, Kronenberg M. The unique role of natural killer T cells in the response to microorganisms. Nat Rev Microbiol 2007;5:405-17. [PubMed: 17487145]

Uchida T, Horiguchi S, Tanaka Y, Yamamoto H, Kunii N, Motohashi S, Taniguchi M, Nakayama T, Okamoto Y. Phase I study of alpha-galactosylceramide-pulsed antigen presenting cells administration to the nasal submucosa in unresectable or recurrent head and neck cancer. Cancer Immunol Immunother 2008;57:337-45. [PubMed: 17690880]

Uldrich AP, Crowe NY, Kyparissoudis K, Pellicci DG, Zhan Y, Lew AM, Bouillet P, Strasser A, Smyth MJ, Godfrey DI. NKT cell stimulation with glycolipid antigen in vivo: costimulation-dependent expansion, Bim-dependent contraction, and hyporesponsiveness to further antigenic challenge. $\mathbf{J}$ Immunol 2005;175:3092-101. [PubMed: 16116198]

van der Vliet HJ, Molling JW, Nishi N, Masterson AJ, Kolgen W, Porcelli SA, van den Eertwegh AJ, von Blomberg BM, Pinedo HM, Giaccone G, Scheper RJ. Polarization of Valpha24+ Vbeta11+ natural killer $\mathrm{T}$ cells of healthy volunteers and cancer patients using alpha-galactosylceramideloaded and environmentally instructed dendritic cells. Cancer Res 2003;63:4101-6. [PubMed: 12874013]

van der Vliet HJ, von Blomberg BM, Nishi N, Reijm M, Voskuyl AE, van Bodegraven AA, Polman CH, Rustemeyer T, Lips P, van den Eertwegh AJ, Giaccone G, Scheper RJ, Pinedo HM. Circulating V 
(alpha24+) Vbeta11+ NKT cell numbers are decreased in a wide variety of diseases that are characterized by autoreactive tissue damage. Clin Immunol 2001;100:144-8. [PubMed: 11465942]

van der Vliet HJ, Wang R, Yue SC, Koon HB, Balk SP, Exley MA. Circulating myeloid dendritic cells of advanced cancer patients result in reduced activation and a biased cytokine profile in invariant NKT cells. J Immunol 2008;180:7287-93. [PubMed: 18490728]

van Dommelen SL, Tabarias HA, Smyth MJ, Degli-Esposti MA. Activation of natural killer (NK) T cells during murine cytomegalovirus infection enhances the antiviral response mediated by NK cells. J Virol 2003;77:1877-84. [PubMed: 12525622]

Van Rhijn I, Young DC, Im JS, Levery SB, Illarionov PA, Besra GS, Porcelli SA, Gumperz J, Cheng TY, Moody DB. CD1d-restricted T cell activation by nonlipidic small molecules. Proc Natl Acad Sci U S A 2004;101:13578-83. [PubMed: 15342907]

Vicari AP, Mocci S, Openshaw P, O'Garra A, Zlotnik A. Mouse gamma delta TCR+NK1.1+ thymocytes specifically produce interleukin-4, are major histocompatibility complex class I independent, and are developmentally related to alpha beta TCR+NK1.1+ thymocytes. Eur J Immunol 1996;26:14249. [PubMed: 8766542]

Vilarinho S, Ogasawara K, Nishimura S, Lanier LL, Baron JL. Blockade of NKG2D on NKT cells prevents hepatitis and the acute immune response to hepatitis B virus. Proc Natl Acad Sci U S A 2007;104:18187-92. [PubMed: 17991774]

Weaver CT, Harrington LE, Mangan PR, Gavrieli M, Murphy KM. Th17: an effector CD4 T cell lineage with regulatory T cell ties. Immunity 2006;24:677-88. [PubMed: 16782025]

Wei DG, Lee H, Park SH, Beaudoin L, Teyton L, Lehuen A, Bendelac A. Expansion and long-range differentiation of the NKT cell lineage in mice expressing CD1d exclusively on cortical thymocytes. J Exp Med 2005;202:239-48. [PubMed: 16027237]

Wilson MT, Van Kaer L. Natural killer T cells as targets for therapeutic intervention in autoimmune diseases. Curr Pharm Des 2003;9:201-20. [PubMed: 12570826]

Wilson SB, Delovitch TL. Janus-like role of regulatory iNKT cells in autoimmune disease and tumour immunity. Nature Reviews Immunology 2003;3:211-222.

Wilson SB, Kent SC, Patton KT, Orban T, Jackson RA, Exley M, Porcelli S, Schatz DA, Atkinson MA, Balk SP, Strominger JL, Hafler DA. Extreme Th1 bias of invariant Valpha24JalphaQ T cells in type 1 diabetes. Nature 1998;391:177-81. [PubMed: 9428763]

Wu D, Xing GW, Poles MA, Horowitz A, Kinjo Y, Sullivan B, Bodmer-Narkevitch V, Plettenburg O, Kronenberg M, Tsuji M, Ho DD, Wong CH. Bacterial glycolipids and analogs as antigens for CD1drestricted NKT cells. Proc Natl Acad Sci U S A 2005;102:1351-6. [PubMed: 15665086]

Yanagisawa K, Exley MA, Jiang X, Ohkochi N, Taniguchi M, Seino K. Hyporesponsiveness to natural killer T-cell ligand alpha-galactosylceramide in cancer-bearing state mediated by CD11b+ Gr-1+ cells producing nitric oxide. Cancer Res 2006;66:11441-6. [PubMed: 17145891]

Yanagisawa K, Seino K, Ishikawa Y, Nozue M, Todoroki T, Fukao K. Impaired proliferative response of $\mathrm{V}$ alpha 24 NKT cells from cancer patients against alpha-galactosylceramide. J Immunol 2002;168:6494-9. [PubMed: 12055270]

Yang JQ, Saxena V, Xu H, Van Kaer L, Wang CR, Singh RR. Repeated alpha-galactosylceramide administration results in expansion of NK T cells and alleviates inflammatory dermatitis in MRLlpr/lpr mice. J Immunol 2003;171:4439-46. [PubMed: 14530371]

Yang L, Anderson DE, Baecher-Allan C, Hastings WD, Bettelli E, Oukka M, Kuchroo VK, Hafler DA. IL-21 and TGF-beta are required for differentiation of human T(H)17 cells. Nature 2008a;454:3502. [PubMed: 18469800]

Yang L, Huang J, Ren X, Gorska AE, Chytil A, Aakre M, Carbone DP, Matrisian LM, Richmond A, Lin PC, Moses HL. Abrogation of TGF beta signaling in mammary carcinomas recruits Gr-1+CD11b + myeloid cells that promote metastasis. Cancer Cell 2008b;13:23-35. [PubMed: 18167337]

Yasunami Y, Kojo S, Kitamura H, Toyofuku A, Satoh M, Nakano M, Nabeyama K, Nakamura Y, Matsuoka N, Ikeda S, Tanaka M, Ono J, Nagata N, Ohara O, Taniguchi M. V\{alpha\}14 NK T celltriggered IFN-\{gamma $\}$ production by Gr-1+CD11b+ cells mediates early graft loss of syngeneic transplanted islets. J Exp Med 2005;202:913-8. [PubMed: 16186183] 
Yoshimoto T, Bendelac A, Hu-Li J, Paul WE. Defective IgE production by SJL mice is linked to the absence of CD4+, NK1.1+ T cells that promptly produce interleukin 4. Proc Natl Acad Sci USA 1995a;92:11931-11934. [PubMed: 8524877]

Yoshimoto T, Bendelac A, Watson C, Hu-Li J, Paul WE. Role of NK1.1+ T cells in a TH2 response and in immunoglobulin E production. Science 1995b;270:1845-7. [PubMed: 8525383]

Yoshimura N, Sawada T, Furusawa M, Fuchinoue S. Expression of xenoantigen transformed human cancer cells to be susceptible to antibody-mediated cell killing. Cancer Lett 2001;164:155-60. [PubMed: 11179830]

Youn HJ, Ko SY, Lee KA, Ko HJ, Lee YS, Fujihashi K, Boyaka PN, Kim SH, Horimoto T, Kweon MN, Kang CY. A single intranasal immunization with inactivated influenza virus and alphagalactosylceramide induces long-term protective immunity without redirecting antigen to the central nervous system. Vaccine 2007;25:5189-98. [PubMed: 17548137]

Zajonc DM, Maricic I, Wu D, Halder R, Roy K, Wong CH, Kumar V, Wilson IA. Structural basis for CD1d presentation of a sulfatide derived from myelin and its implications for autoimmunity. J Exp Med 2005;202:1517-26. [PubMed: 16314439]

Zea AH, Rodriguez PC, Atkins MB, Hernandez C, Signoretti S, Zabaleta J, McDermott D, Quiceno D, Youmans A, O’Neill A, Mier J, Ochoa AC. Arginase-producing myeloid suppressor cells in renal cell carcinoma patients: a mechanism of tumor evasion. Cancer Res 2005;65:3044-8. [PubMed: 15833831]

Zeng D, Dick M, Cheng L, Amano M, Dejbakhsh-Jones S, Huie P, Sibley R, Strober S. Subsets of transgenic T cells that recognize CD1 induce or prevent murine lupus: role of cytokines. J Exp Med 1998;187:525-36. [PubMed: 9463403]

Zhou D, Cantu C 3rd, Sagiv Y, Schrantz N, Kulkarni AB, Qi X, Mahuran DJ, Morales CR, Grabowski GA, Benlagha K, Savage P, Bendelac A, Teyton L. Editing of CD1d-bound lipid antigens by endosomal lipid transfer proteins. Science 2004a;303:523-7. [PubMed: 14684827]

Zhou D, Mattner J, Cantu C 3rd, Schrantz N, Yin N, Gao Y, Sagiv Y, Hudspeth K, Wu YP, Yamashita T, Teneberg S, Wang D, Proia RL, Levery SB, Savage PB, Teyton L, Bendelac A. Lysosomal glycosphingolipid recognition by NKT cells. Science 2004b;306:1786-9. [PubMed: 15539565]

Zimmer MI, Colmone A, Felio K, Xu H, Ma A, Wang CR. A cell-type specific CD1d expression program modulates invariant NKT cell development and function. J Immunol 2006;176:1421-30. [PubMed: 16424169] 


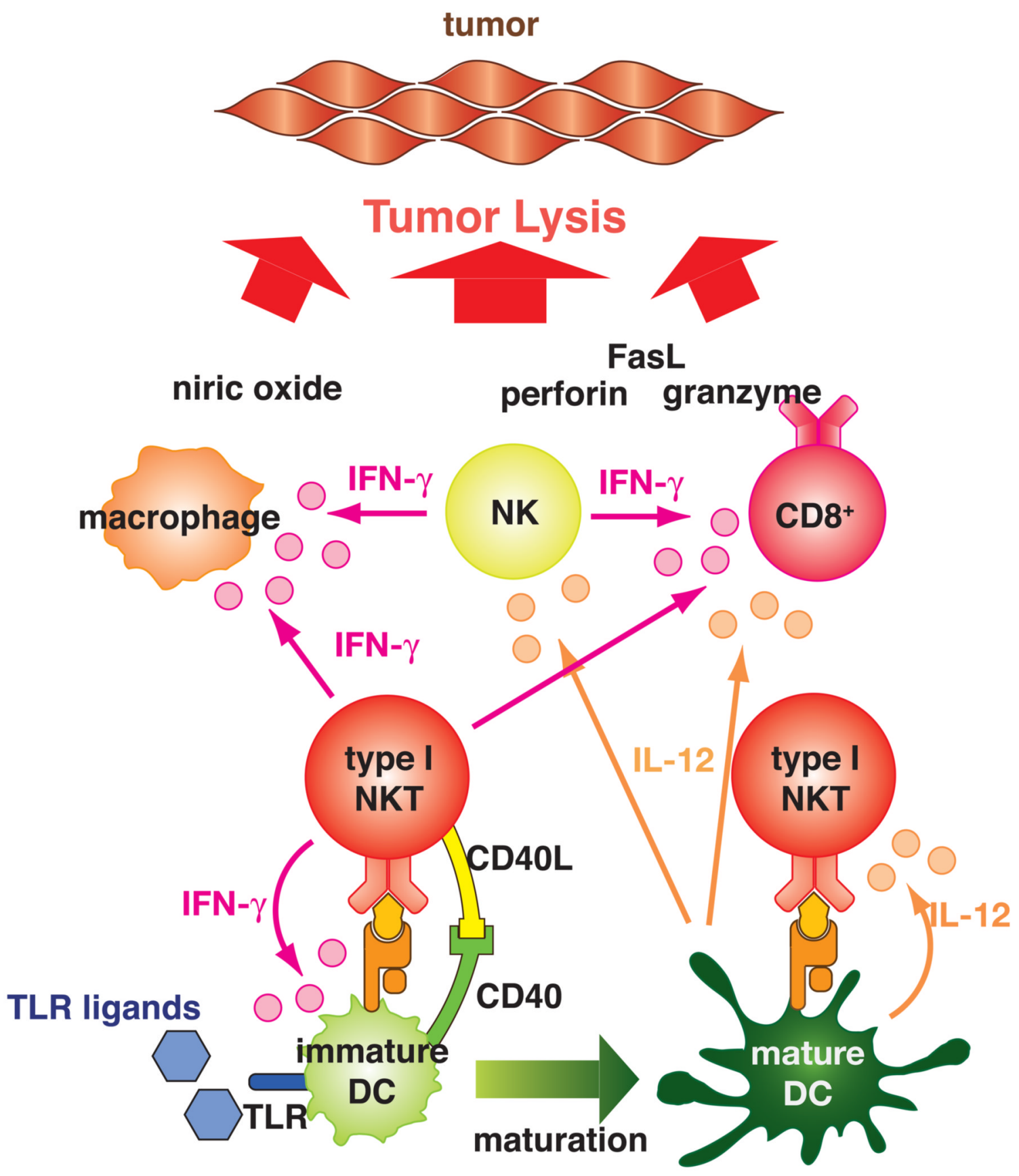

Fig. 1.

Type I NKT cells promote tumor immunity.

When type I NKT cells are activated by $\alpha$-GalCer or endogenous glycolipids (may be tumor derived) presented by CD1d on immature dendritic cells (DCs), they produce interferon- $\gamma$ (IFN- $\gamma$ ). The type I NKT cells may also interact with the immature DCs through CD40-CD40L. This interaction and IFN- $\gamma$ induce maturation of the DCs. The mature DCs produce IL-12, which augments IFN- $\gamma$ and IL-2 production by type I NKT cells. IFN- $\gamma$ and IL-2 from the type I NKT cells and IL-12 from the mature DCs activate NK cells, CD8 ${ }^{+} \mathrm{T}$ cells, and macrophages. Exogenous IL-12 may bypass the process of DC maturation induced by the activated type I NKT cells. Providing exogenous Toll-like receptor (TLR) ligands may strengthen the cytokine 
production. Cross-presentation of tumor antigens by antigen presenting cells to $\mathrm{CD} 8^{+} \mathrm{T}$ cells when activated by the type I NKT cells may enhance induction of tumor antigen-specific $\mathrm{CD} 8^{+} \mathrm{T}$ cells. These activated $\mathrm{T}$ cells lyse tumor cells by employing multiple effector mechanisms including perforin, granzyme, FasL, and nitric oxide. 

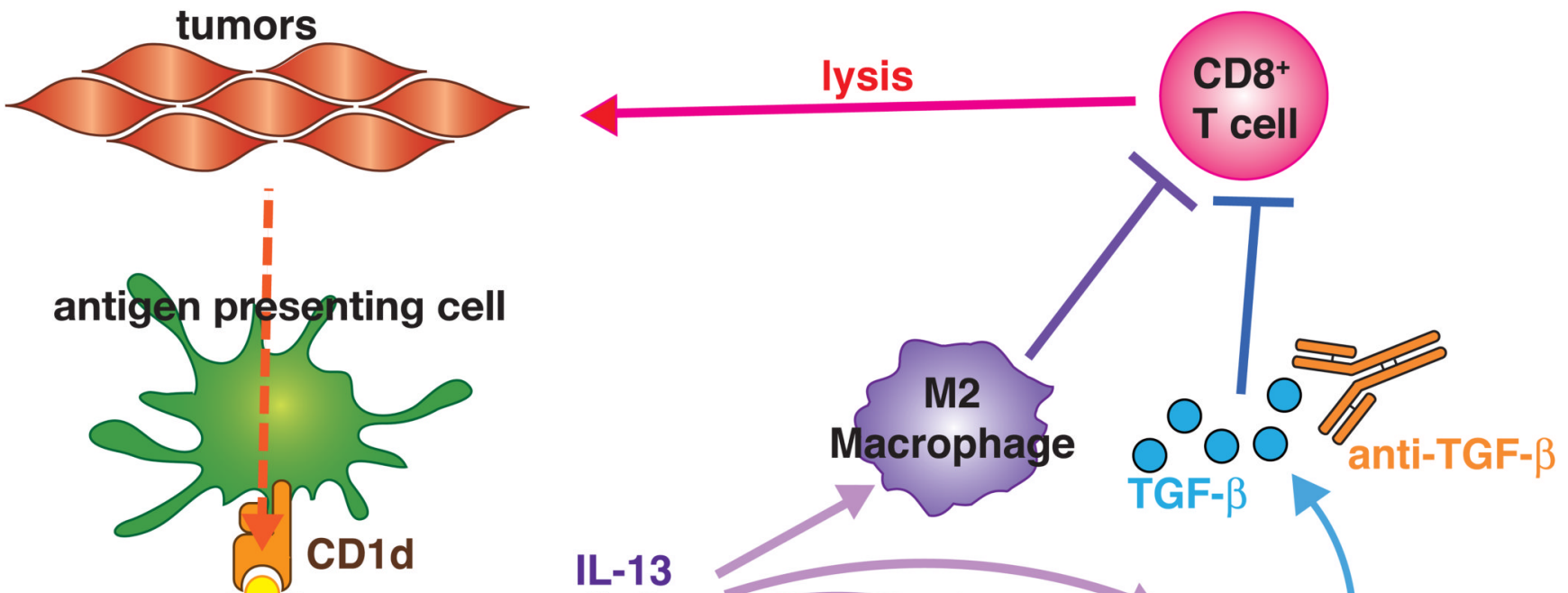

ค

CD1d

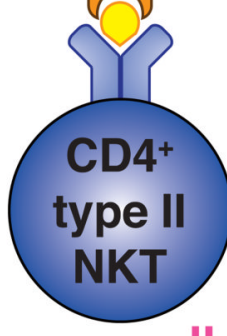

IL-13 inhibitor

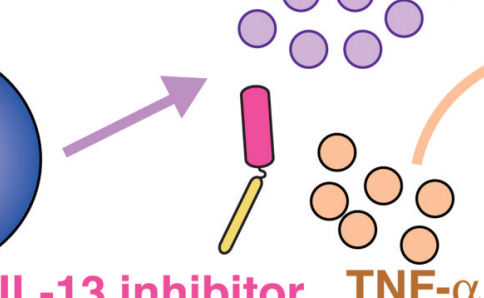

TNF- $\alpha$

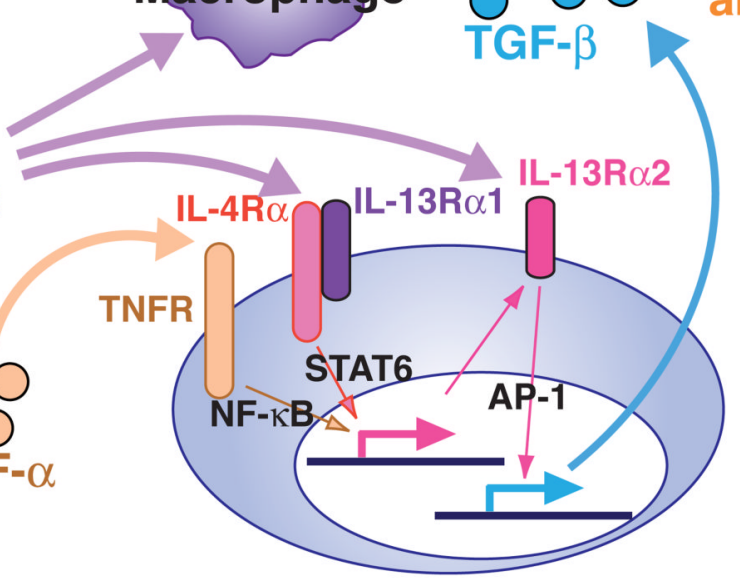

CD11b+Gr-1+ myeloid cells

Fig. 2.

Type II NKT cells suppress tumor immunity.

When type II NKT cells (mostly $\mathrm{CD}^{+}$) are activated by tumor-derived glycolipids presented by CD1d, they produce IL-13. Together with TNF- $\alpha$ in the microenvironment signaling through TNF-receptor (TNFR) and NF- $\mathrm{BB}$, IL-13 signals through a type II IL-4 receptor (IL-4R), a heterodimer of an IL-4R $\alpha$ and an IL-13R $\alpha 1$, and STAT6 to induce expression of the IL-13R $\alpha 2$ on a CD $11 b^{+} \mathrm{Gr}-1^{+}$myeloid cell. The IL-13R $\alpha 2$ binding to IL-13 transduces a signal through AP-1, which induces expression of TGF- $\beta$. TGF- $\beta$ suppresses activation of tumor specific $\mathrm{CD}^{+} \mathrm{T}$ cells, which mediate regression of tumors. In some tumor settings, IL-13 may induce M2 macrophages that also suppress CD8 ${ }^{+}$T cells. Blockade of either IL-13 by an IL-13 inhibitor such as soluble IL-13R $\alpha 2$, or TGF- $\beta$ with anti-TGF- $\beta$ antibodies, or TNF$\alpha$ with a TNF- $\alpha$ antagonist can remove the suppression. Modified from (Terabe, et al., 2003a) with permission. 


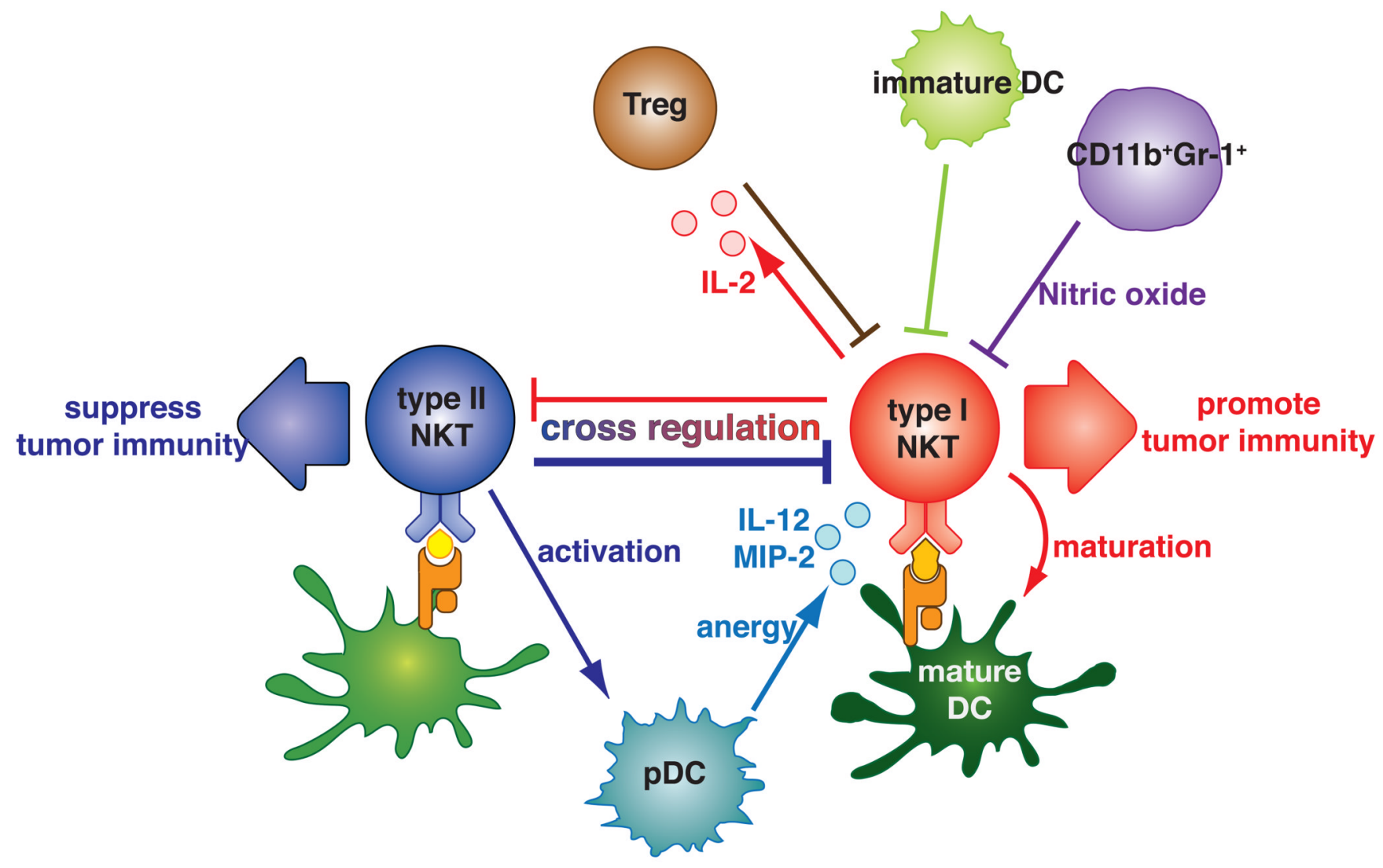

Fig. 3.

Cross-regulation of type I and type II NKT cells-a new immunoregulatory axis. Type I and type II NKT cells cross-regulate each other. Type II NKT cells suppress tumor immunity when they are activated (by recognizing sulfatide or another lipid presented by CD1d). In some settings, the type II NKT cells suppress type I NKT cells. It is reported that sulfatide activated type II NKT cells activate plasmacytoid DCs (pDC) to produce IL-12 and MIP-2, which recruit and lead to the anergy of type I NKT cells. Activated type I NKT cells induce DC maturation and promote tumor immunity. It is also possible that IL-2 production by activated type I NKT cells supports regulatory T cells, which can suppress type I NKT cells. Immature DCs and CD $11 b^{+} \mathrm{Gr}-1^{+}$myeloid cells may also suppress type I NKT cells in some tumor settings. The cross-regulation between type I and type II NKT cells defines a new immunoregulatory axis like the Th1-Th2 axis. The balance along this axis may in part determine the outcome of tumor immunity. Manipulation of this balance may be critical for the successful immunotherapy of cancer. 